Andrews University

Digital Commons @ Andrews University

\title{
The Role of the Pastor in Equipping the Laity for Ministry in the West Jamaica Conference of Seventh-day Adventists
}

Eldon Gosnel Walker

Andrews University

Follow this and additional works at: https://digitalcommons.andrews.edu/dmin

Part of the Practical Theology Commons

\section{Recommended Citation}

Walker, Eldon Gosnel, "The Role of the Pastor in Equipping the Laity for Ministry in the West Jamaica Conference of Seventh-day Adventists" (2003). Professional Dissertations DMin. 578.

https://dx.doi.org/10.32597/dmin/578

https://digitalcommons.andrews.edu/dmin/578

This Project Report is brought to you for free and open access by the Graduate Research at Digital Commons @ Andrews University. It has been accepted for inclusion in Professional Dissertations DMin by an authorized administrator of Digital Commons @ Andrews University. For more information, please contact repository@andrews.edu. 


\section{ABSTRACT \\ THE ROLE OF THE PASTOR IN EQUIPPING THE LAITY FOR MINISTRY IN THE WEST JAMAICA CONFERENCE \\ OF SEVENTH-DAY ADVENTISTS}

\section{by}

Eldon Gosnel Walker

Adviser: R. Clifford Jones 


\title{
ABSTRACT OF GRADUATE STUDENT RESEARCH
}

\section{Dissertation}

\author{
Andrews University \\ Seventh-day Adventist Theological Seminary
}

\author{
Title: THE ROLE OF THE PASTOR IN EQUIPPING THE LAITY FOR MINISTRY \\ IN THE WEST JAMAICA CONFERENCE OF SEVENTH-DAY ADVENTISTS \\ Name of researcher: Eldon G. Walker \\ Name and degree of faculty adviser: R. Clifford Jones, D.Min., Ph.D. \\ Date completed: December 2003
}

\section{Problem}

In spite of the urgent need to train and equip the laity for ministry in the West Jamaica Conference of Seventh-day Adventists, no serious strategy has been developed to prepare the pastors to meet this problem. This study seeks to evaluate the current practices that are being used by pastors and to suggest strategies that will help them to identify their role in equipping the laity for ministry. 


\section{Method}

Current literature was reviewed on the principles, strategies, and programs related to equipping the laity for ministry. Valuable to this study were books and literature written in Jamaica which provided a historical framework of the Jamaica context. On May 2002, I traveled to Jamaica, where I conducted a survey involving the thirty-six pastors who serve the 196 churches of the West Jamaica Conference. These churches include 61,858 members. A survey was conducted involving a sampling of the members in at least two of the churches assigned to each pastor. A descriptive analysis of the data is included in the study. A strategy to help pastors equip the laity for ministry was developed.

\section{Conclusions}

This research has shown that training the laity for ministry is an important part of the pastor's role in the local church. Therefore, the strategies that are outlined in this research will help prepare the pastors to train the laity. It is expected that the strategies suggested will mobilize the entire church for total participation. The principles can be adapted to meet similar needs in other conferences. 
Andrews University

Seventh-day Adventist Theological Seminary

\title{
THE ROLE OF THE PASTOR IN EQUIPPING THE LAITY FOR MINISTRY IN THE WEST JAMAICA CONFERENCE OF SEVENTH-DAY ADVENTISTS
}

\author{
A Dissertation \\ Presented in Partial Fulfillment \\ of the Requirements for the Degree \\ Doctor of Ministry \\ by
}

Eldon Gosnel Walker

December 2003 



\title{
THE ROLE OF THE PASTOR IN EQUIPPING THE LAITY FOR MINISTRY IN THE WEST JAMAICA CONFERENCE OF SEVENTH-DAY ADVENTISTS
}

\author{
A dissertation \\ presented in partial fulfillment \\ of the requirements for the degree \\ Doctor of Ministry
}

by

Eldon Gosnel Walker
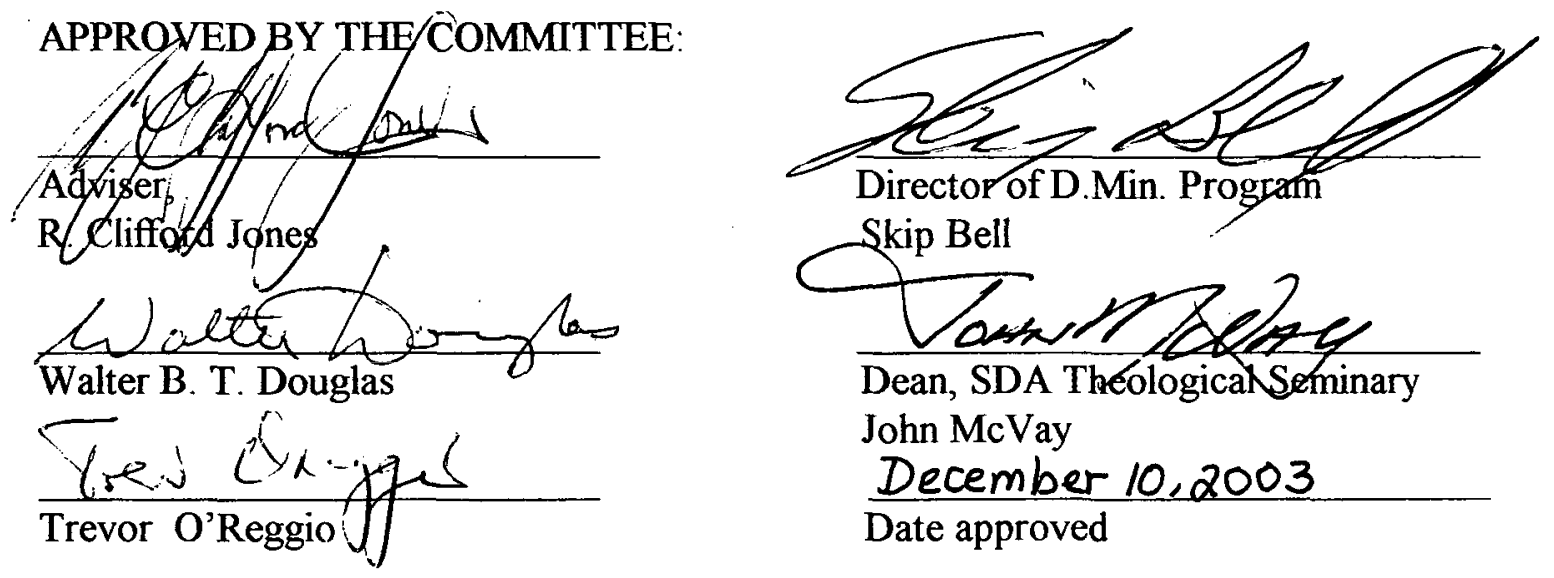
To

my wonderful mother,

my darling wife, Pauline, and

my two loving children, Donnel and Donnene 


\section{TABLE OF CONTENTS}

LIST OF TABLES $\ldots \ldots \ldots \ldots \ldots \ldots \ldots \ldots \ldots \ldots \ldots \ldots \ldots \ldots \ldots \ldots \ldots$

ACKNOWLEDGMENTS $\ldots \ldots \ldots \ldots \ldots \ldots \ldots \ldots \ldots \ldots \ldots \ldots \ldots$

Chapter

1. INTRODUCTION $\ldots \ldots \ldots \ldots \ldots \ldots \ldots \ldots \ldots \ldots \ldots \ldots \ldots$

Statement of the Problem $\ldots \ldots \ldots \ldots \ldots \ldots \ldots \ldots \ldots$

Purpose of the Dissertation $\ldots \ldots \ldots \ldots \ldots \ldots \ldots \ldots$

Justification of the Dissertation $\ldots \ldots \ldots \ldots \ldots \ldots \ldots \ldots$

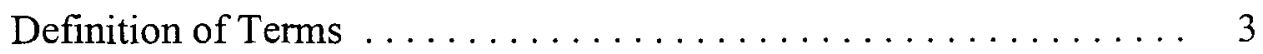

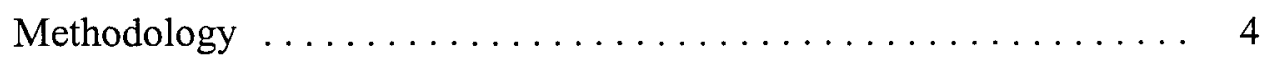

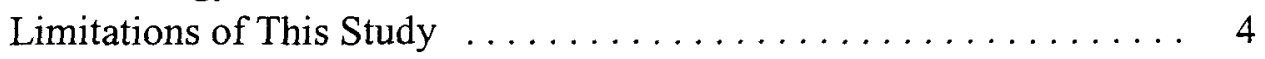

Expectations of the Dissertation $\ldots \ldots \ldots \ldots \ldots \ldots \ldots$

2. HISTORICAL OVERVIEW OF JAMAICA AND A BRIEF HISTORY OF ADVENTISM IN THE WEST JAMAICA CONFERENCE . . . . . . 6

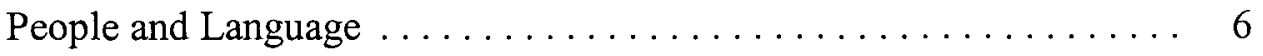

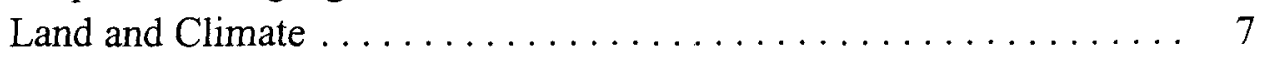

Socioeconomic and Political Factors . . . . . . . . . . . 8

The Development of Adventism in Jamaica . . . . . . . . . . . 11

Adventism Goes to Trelawny . . . . . . . . . . . . . . 16

Adventism Goes from Trelawny to Spanish Town . . . . . . . 17

Adventism Moves to Hanover . . . . . . . . . . . . . . . . 17

Adventism Goes to Westmoreland . . . . . . . . . . . . 18

Adventism Goes to St. Elizabeth . . . . . . . . . . . . 18

Adventism Goes to St. James . . . . . . . . . . . . . . . . . . . 19

The Organization of the West Jamaica Conference . . . . . . . 20

The Growth of the West Jamaica Conference . . . . . . . . . 21 


\section{BIBLICAL AND THEOLOGICAL FOUNDATIONS FOR}

EQUIPPING THE LAITY $\ldots \ldots \ldots \ldots \ldots \ldots \ldots \ldots \ldots \ldots \ldots \ldots \ldots \ldots$

The Equipping Strategies of Moses $\ldots \ldots \ldots \ldots \ldots \ldots \ldots \ldots \quad 24$

Moses Trained a Successor ........................ 26

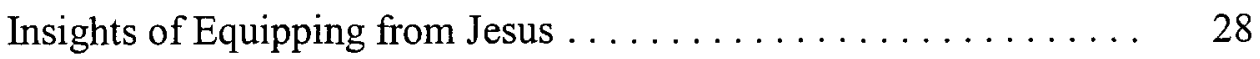

Definition of a Disciple .......................... $\quad 29$

Discipleship in the Time of Jesus ................ $\quad 30$

Jesus' Call to His Disciples ....................... $\quad 32$

The Training of Jesus' Disciples $\ldots \ldots \ldots \ldots \ldots \ldots \ldots . \quad 33$

Jesus Equipped His Disciples by Training Them ......... 35

Equipping in the Early Church ................... 38

The Early Church Faced Persecution $\ldots \ldots \ldots \ldots \ldots \ldots . \quad 39$

Strategies Used in the Early Church ................. 40

Description of the Early Church ................. 41

Pauline Model of Equipping $\ldots \ldots \ldots \ldots \ldots \ldots \ldots \ldots .43$

Paul Equips House Churches During His Ministry ......... 44

Equipping the Church Through Spiritual Gifts $\ldots \ldots \ldots \ldots \ldots .46$

Equipping the Church Through Training ............... 48

Ellen White's Counsel on the Role of Small Groups

in Equipping the Laity for Ministry ............... 50

The Influence of Methodism on Ellen White's

Spiritual Life ........................... 50

Equipping the Laity in Early Adventism $\ldots \ldots \ldots \ldots \ldots \ldots \ldots . \ldots \ldots$

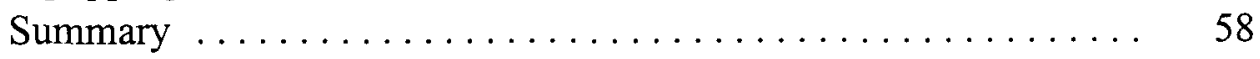

4. ANALYSIS OF FIELD SURVEYS FOR PASTORS AND

MEMBERS OF THE. WJC OF SDA $\ldots \ldots \ldots \ldots \ldots \ldots \ldots \ldots$

Rationale for the Surveys $\ldots \ldots \ldots \ldots \ldots \ldots \ldots \ldots \ldots \ldots .60$

The Survey Given to the SDA Pastors in the WJC . . . . . . . 61

The Survey of SDA Members $\ldots \ldots \ldots \ldots \ldots \ldots \ldots \ldots .62$

Methodology ............................... 63

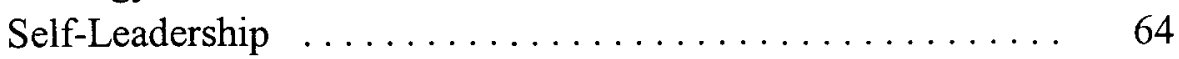

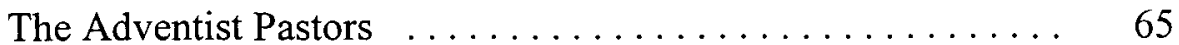

The Pastor and His/Her Understanding of Ministry ......... 75

Pastors' Suggestions for Equipping the Laity $\ldots \ldots \ldots \ldots \ldots .78$

The Survey for the SDA Members ................. 81

Members' Suggestions for Equipping the Laity $\ldots \ldots \ldots \ldots \ldots . \quad 88$

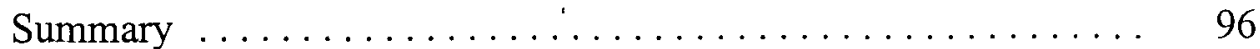




\section{A STRATEGY FOR PASTORS TO EQUIP THE LAITY FOR MINISTRY IN THE WEST JAMAICA CONFERENCE OF SDA $\ldots . \quad 98$}

Defining a Strategy $\ldots \ldots \ldots \ldots \ldots \ldots \ldots \ldots \ldots \ldots \ldots \ldots$

Developing a Successful Strategy for Equipping the Laity ...... . 101

The First Seminars: Pastoral Self-Leadership . . . . . . . . . . . 102

Instructor of the Seminars . . . . . . . . . . . . . . . . 103

Purpose of the Seminars ...................... 103

Objectives of the Seminar $\ldots \ldots \ldots \ldots \ldots \ldots \ldots \ldots \ldots \ldots \ldots$

Description of the Seminar .................... 111

Seminar Content ......................... 111

The Second Seminar: Pastoral Leadership . . . . . . . . . . . . . 113

Purpose of the Seminar ...................... 115

Description of the Seminar ..................... 115

Objectives of the Seminar $\ldots \ldots \ldots \ldots \ldots \ldots \ldots \ldots, 116$

Seminar Content ......................... 116

The Third Seminar: The Role of the Pastor in Equipping the Laity . 118

Purpose of the Seminar ...................... 122

Description of the Seminar .................... 122

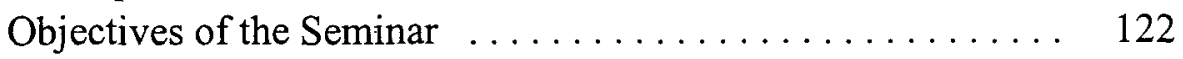

Seminar Content ............................ 123

The Fourth Seminar: A Model to Equip the Laity . . . . . . . . . . 124

Description of the Seminar .................... 125

Purpose of the Seminar....................... 125

Developing a Strategy to Equip the Laity for Ministry . . . . . . . 129

Definition of a Small Group ...................... 131

Keys to a Successful Small Group ................. 132

Small Group in Acts $2 \ldots \ldots \ldots \ldots \ldots \ldots \ldots \ldots \ldots . \ldots \ldots . \ldots \ldots$

Types of Small Groups ....................... 134

Conditions Needed for the Growth of Small Groups ....... 135

Importance of the Leader of the Small Group . . . . . . . . 136

Qualifications of the Leader . . . . . . . . . . . . . . . 136

Leadership Styles .......................... 137

Leadership Meeting of Small Groups . . . . . . . . . . . . . . 138

Seminar Content ........................... 138

Expected Results of the Seminars . . . . . . . . . . . . . . . 139

Consecration/Award Service . . . . . . . . . . . . . . . 140

Assessment .............................. 140

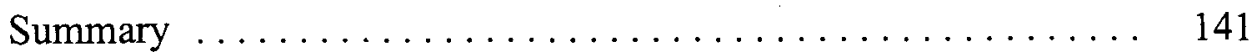


Summary

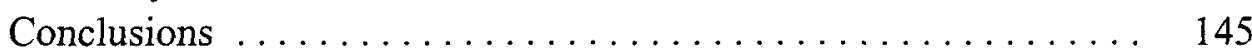

Recommendations ........................ 146

Appendix
A. SEMINAR ON SELF-LEADERSHIP . . . . . . . . . . . 148

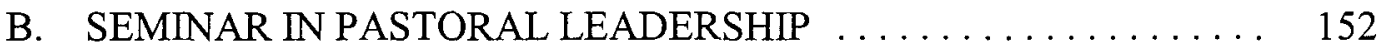
C. SEMINAR ON THE ROLE OF THE PASTOR IN EQUIPPING THE LAITY . . . . . . . . . . . . . . . 156
D. SEMINAR ON DEVELOPING A MODEL TO

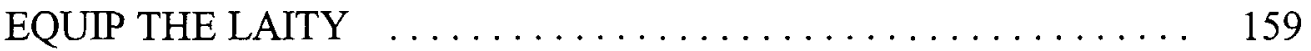

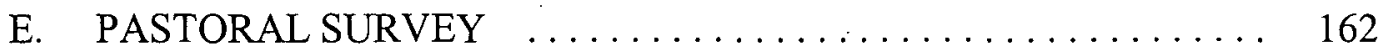
F. MEMBER SURVEY $\ldots \ldots \ldots \ldots \ldots \ldots \ldots \ldots \ldots \ldots \ldots \ldots \ldots$

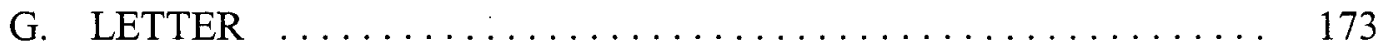
H. SEMINAR EVALUATION $\ldots \ldots \ldots \ldots \ldots \ldots \ldots \ldots \ldots \ldots \ldots \ldots$

BIBLIOGRAPHY $\ldots \ldots \ldots \ldots \ldots \ldots \ldots \ldots \ldots \ldots \ldots \ldots \ldots \ldots \ldots$

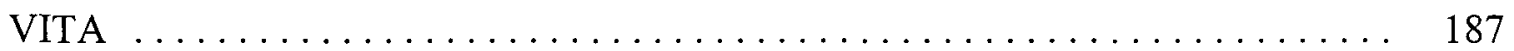




\section{LIST OF TABLES}

1. Organization of Jamaica Conferences in West Indies Union $\ldots \ldots \ldots \ldots \ldots 21$

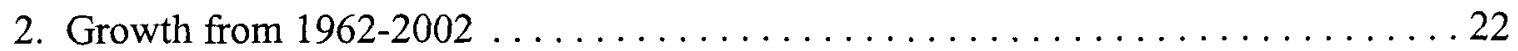

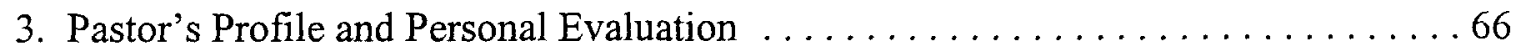

4. The Pastor's Understanding of His/Her Role in Leadership . . . . . . . . . . . 70

5. The Pastor and His/Her Relationship to the Conference $\ldots \ldots \ldots \ldots \ldots \ldots 73$

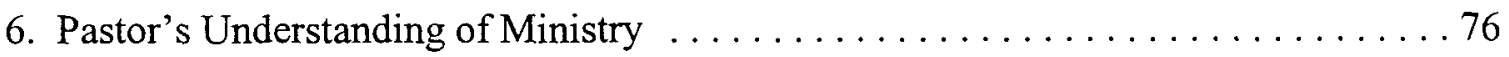

7. Suggestions from Pastors in Equipping the Laity $\ldots \ldots \ldots \ldots \ldots \ldots \ldots$

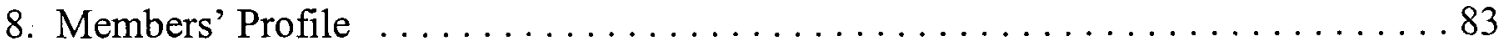

9. Members' Understanding of Pastoral Leadership ................... 85

10. Members and Their Understanding of Church Ministry ............... 87

11. Members' Evaluation of Their Personal Ministry $\ldots \ldots \ldots \ldots \ldots \ldots \ldots . \ldots . \ldots 9$

12. Members' Suggestions on How Pastors Should Equip the Laity . . . . . . . . . 92

13. Location and Schedule of the Seminar for Three-Month Training Seminars . . . 110 


\section{ACKNOWLEDGMENTS}

I would like to express my deepest gratitude to my Lord and Savior Jesus Christ for His providential leading in my life, and for calling me to the gospel ministry. To Him be all the glory, honor, and praise. My heartfelt gratitude goes to the following persons:

To my dearly beloved mother, Mrs. Inez Walker, who never surrendered when times were extremely difficult for her and her thirteen children. My mother would say to me, "Danny, the Lord will make a way." "God bless you, Mama."

To my faithful, devoted, and visionary wife, Pauline, whose determination and energy contributed significantly to my humble success.

To my wonderful children, Donnel and Donnene, who sometimes in the midst of my studies would say to me, "Daddy, please play with us." I love you both.

To Dr. R. Clifford Jones, Walter B. T. Douglas, and Trevor O’Reggio whose patience, wisdom, guidance, and technical support provided the motivation I needed in order to make this dissertation a reality.

To the Doctor of Ministry Director, Dr. Skip Bell, who was understanding of my request for scholarship, and to Rita Pusey, whose administrative skills gave me steady progress.

To Dr. Walter Douglas, who gave me the opportunity to serve at the All Nations 
SDA church, and Mrs. Shermette Brown, who encouraged me to get involved.

To Jeanette Bryson whose creative ability and resourcefulness proved invaluable.

To the members of my home church, Delveland Seventh-day Adventist Church, who earnestly prayed for me when I was going to West Indies College.

To West Jamaica Conference and all the churches where I was privileged to serve.

To Pastor N. Harding, his wife Sheron and the children.

To Elder Edwards and all the Members of the Margate Mission.

To my five brothers and six sisters, Essie, Reuben, Sadie, Vee, Rally, Dassie, Verley, Homie, Wisy, Valerie, and Barry, who supported me throughout life's challenges.

To Dr. Wills Dixon and his wife, who stood by my family from the early stages of our dream to attend Andrews University.

To Pastor Watson Afaese from Samoa, who said to me, "Eldon, you must have a plan to train the laity."

To my prayer partner and friend at Andrews University, Kenaope Kenaope, from Botswana, whose encouragement, support, and prayer will be forever etched in my mind.

To Henerica Hamilton whose secretarial skills helped me along the way.

To the insightful, energetic Bonnie Beres who worked tirelessly typing this entire manuscript.

To God, who has begun a good work in me and will finish it unto the coming of our Lord and Savior Jesus Christ (Phil 1:6). 


\section{CHAPTER 1}

\section{INTRODUCTION}

\section{Statement of the Problem}

In spite of the urgent need to train and equip the laity for ministry in the West Jamaica Conference of Seventh-day Adventists, no serious strategy has been developed to prepare the pastors to meet this problem. This study seeks to evaluate current practices that are used by pastors and suggests strategies that will help them to identify their role in equipping the laity for ministry.

\section{Purpose of the Dissertation}

The purpose of the dissertation is to identify the role of the pastor in equipping the laity for ministry in the West Jamaica Conference of Seventh-day Adventists.

\section{Justification of the Dissertation}

The following reasons justify the need for pastors to equip the laity for ministry in the West Jamaica Conference of Seventh-day Adventists:

1. There is biblical evidence to show that the pastors have a responsibility to equip the laity for ministry. 
2. In order for the gospel to reach every nation, kindred, tongue, and people, the laity must be equipped to teach others about it.

3. Ellen G. White counsels that pastors should equip the laity for ministry. She states that the greatest help that pastors can give to members is to teach them to work for God, and depend on Him, and not on the pastor. ${ }^{1}$

4. Pastors must recognize that their role is not to maintain and give primary care, but to educate and train the members. Church members who are not trained as disciples will depend too much on the pastor to do the work.

5. If pastors do not equip the members, there is a strong possibility that pastors will become frustrated, stressed out, and burned out.

6. There a need for pastors to understand that ministry is not the prerogative of the pastor alone. Rick Warren states that every believer is not a pastor, but every believer is called into ministry. ${ }^{2}$

7. Denominational leaders in the West Jamaica Conference recognize the need to equip the laity for ministry and would benefit from strategies for implementation.

'Ellen G. White, Testimonies for the Church, 9 vols. (Mountain View, CA: Pacific Press Publishing Association, 1948), 7:19.

${ }^{2}$ Rick Warren, The Purpose Driven Church (Grand Rapids, MI: Zondervan Publishing House, 1995), 368. 


\section{Definition of Terms}

The following terms are defined as used in this study:

Role: A function performed by someone in a particular situation, process, or operation.

Adventist: A shortened form for Seventh-day Adventist Church.

Church: A congregation of believers who assemble together in a specific locality. ${ }^{1}$

Ministry: A distinctive biblical concept which means to serve or service. In reality all believers are ministers. ${ }^{2}$

Strategy: An elaborate and systematic plan of action.

Laity: The people of God which includes both pastors and members.

Member: A person who is fully accepted as a part of a local congregation according to the requirements of the Seventh-day Adventist Church Manual. ${ }^{3}$

Pastor: The feeder, protector, and guide or shepherd of a flock of God's people.

${ }^{1}$ Seventh-day Adventists Believe . . . : A Biblical Exposition of 27 Fundamental Doctrines (Hagerstown, MD: Review and Herald Publishing Association, 1988), 136.

${ }^{2}$ Nelson New Illustrated Bible Dictionary, ed. Ronald F. Youngblood (Nashville, TN: Thomas Nelson Publishers, 1986), 845.

${ }^{3}$ Seventh-day Adventist Church Manual, rev. $16^{\text {th }}$ ed. (Hagerstown, MD: Review and Herald Publishing Association, 2000), 30. 
West Jamaica Conference of Seventh-day Adventists (WJC): St. Elizabeth, St.

James, Westmoreland, and Hanover parishes in West Jamaica in the West Indies Union.

Seventh-day Adventist: The official name of the world-wide Seventh-day

Adventist church.

\section{Methodology}

Current literature was reviewed on the principles, strategies, and programs related to equipping the laity for ministry. Valuable to this study were books and literature written in Jamaica which provided a historical framework of the Jamaica context. In May 2002, I traveled to Jamaica, where I conducted a survey involving the thirty-six pastors who serve the 196 churches of the West Jamaica Conference. These churches include 61,858 members. A survey was conducted involving a sampling of the members in the main church assigned to each pastor. A descriptive analysis of the data was included in the study. A strategy to help pastors equip the laity for ministry was developed.

\section{Limitations of This Study}

This study was limited to the challenges of equipping the laity in West Jamaica Conference. Surveys were limited to discover the current practices used by pastors in equipping the laity in the West Jamaica Conference. In addition, lay members from selected churches were surveyed to find out their perceptions and suggestions regarding the equipping strategies used by the pastors. The historical background of Adventism in 
Jamaica was limited to an overview of its origin, expansion, and the involvement of lay members in West Jamaica Conference.

\section{Expectations of the Dissertation}

The following expectations are anticipated from this dissertation:

1. This study will help me to develop my personal leadership skills, and provide me with strategies that I can utilize to equip the laity for ministry.

2. The results of this study will provide strategies for pastors to use when equipping the members for ministry in West Jamaica Conference of Seventh-day Adventists.

3. This study will provide guidelines to be used to conduct workshops and weekend seminars to train pastors and lay-members for ministry.

4. Members will be equipped to give primary care to local churches instead of the pastor providing this ministry alone.

5. Members will be able to identify their gifts in order to witness effectively. Members working in their areas of giftedness will create a dynamic, vibrant church.

6. The result of this project will encourage pastors to train members to work for others. This should ensure a sustained church growth in the West Jamaica Conference. 


\section{CHAPTER 2}

\section{HISTORICAL OVERVIEW OF JAMAICA AND A BRIEF HISTORY \\ OF ADVENTISM IN THE WEST JAMAICA CONFERENCE}

This chapter presents an overview of Jamaica and a brief historical background of the Seventh-day Adventist Church there. The first section briefly outlines the people and language, land and climate, and the socioeconomic and political factors in Jamaica. The second section gives a historical overview of the Seventh-day Adventist Church, with a particular focus on the West Jamaica Conference.

\section{People and Language}

Jamaica in 2002 had a population of $2,763,466{ }^{1}$. When Christopher Columbus arrived in Jamaica in 1494, the island was inhabited by 60,000 to 75,000 indigenous people. $^{2}$ In 1509 the Spaniards colonized Jamaica, which they called Xaymaca (a land of wood and water). When the English captured Jamaica in 1655 they changed the name to Jamaica.

'CIA, "Jamaica," The World Factbook, 2002, http://www.odci.gov/cia/publications/factbook/print/jm.html (2 November 2002).

${ }^{2}$ Samuel J. Hurwitz and Edith F. Hurwitz, Jamaica: A Historical Portrait (New York: Praegers Publishers, 1971), 5. 
Long before the colonialists arrived, Jamaica had been inhabited by an indigenous, gentle, peaceful tribe from South America. ${ }^{1}$ These indigenous peoples were called Tainos and were a branch of the Arawaks, the general name given to the Indian inhabitants of the Caribbean Isles. ${ }^{2}$ Even though the Tainos were hospitable and generous toward the Spaniards, the Spaniards repaid the hospitality by carrying out an extermination of these aboriginal inhabitants. ${ }^{3}$

Currently, the statistics show a strong African heritage with 90.9 percent of the inhabitants of African descent; East Indian, 1.3 percent; White, 0.2 percent; Chinese, 0.2 percent; mixed, 7.3 percent; and other, 0.1 percent. ${ }^{4}$ As a result of the diverse population, Jamaica adopted a motto that depicts the country's multi-ethnicity: "Out of Many One People." English is the official language, and patois, a combination of English, Spanish, and some African dialects, is the national language. ${ }^{5}$

\section{Land and Climate}

Jamaica is the third largest island of the Greater Antilles and the largest of the Englishspeaking islands of the Caribbean. The islands of the Caribbean are called The West Indian Archipelago. Jamaica runs east to west, 146 miles and 51 miles at its widest, and has an area

'Margaret Morris, Tour Jamaica (Kingston, Jamaica: The Gleaner Co., 1985), 9.

${ }^{2}$ Ibid.

${ }^{3}$ Clinton V. Black, The Story of Jamaica: From Pre-historic to Present (London: Collins Clear Type Press, 1965), 12.

${ }^{4}$ CIA, Jamaica (2 November 2002).

${ }^{5}$ Morris, 15 . 
of 4,411 square miles. It is 90 miles south of Cuba, and about the same distance west of Haiti. ${ }^{1}$ The climate is tropical but tempered by the sea, the temperature varying from 60 degrees in the mountains to more than 90 degrees in the hot coastal plains. ${ }^{2}$

The average annual rainfall ranges from 300 inches on the eastern slopes of the Blue Mountain to 230 inches in some other parts of the south coast. During the coolest months, December to March, the island sometimes experiences what is called the "northern chill winds" and high seas associated with a cold front from the north. July to September are the warmest months, and May to October are traditionally the rainy months. ${ }^{3}$ The current weather patterns have become increasingly erratic. Environmentalists attribute the change in weather to deforestation and global warming.

\section{Socioeconomic and Political Factors}

"The Jamaica Survey of Living Conditions 2000 Report issued by the Planning Institute of Jamaica (PIOJ) has revealed that the percentage of the population below the poverty line has increased from 1999 , moving from 16.9 percent to 18.7 percent. Trends in the incidence of poverty data reveal that," after peaking at 44.6 percent in 1991, "there were steady decreases in the rate until 1998, and increases thereafter." ${ }^{.4}$

\footnotetext{
'Clinton V. Black, Jamaica Guide (London: Clear Type Press, 1973), 8.

${ }^{2}$ Henriques Fernando, Jamaica, Land of Wood and Water (New York: Maxwell Publishers, 1964), 11.

${ }^{3}$ Morris, 8.

4"Poverty on the Rise," The Jamaica Gleaner, October 19, 2001, 12, www.jamaicagleaner.com
} 
The rural areas remain particularly vulnerable to poverty due to fewer opportunities to obtain an education and to remain gainfully employed. The low income does not provide an opportunity to improve the present conditions or even to set aside monies to have a cushion in times of economic slowdown. Rural development has been a longstanding concern for Jamaica, and the perpetuation of these problems highlights the need for intensification of policies and activities designed to improve conditions.

Jamaica, like much of the developing world, continues to wrestle with issues of financial inequities. Some features of the poor have remained unassailable, with persons in the rural areas twice as likely as their urban counterpart to be poor. The poor have lower levels of education. Their children participate largely at the lower levels of the educational system. Their households are larger and they are more likely to share basic housing amenities with members of the extended family.

Jamaica is a constitutional parliamentary democracy. It gained full independence from the British Commonwealth on August 6, 1962. ${ }^{1}$ Every five years, Jamaicans eighteen years of age and over elect a government of their choice. The parliamentary government consists of the Prime Minister and a House of elected members representing sixty constituencies and a Senate of twenty-one members, fourteen of them nominated by the Prime Minister and eight by the Leader of the Opposition. ${ }^{2}$ Jamaica is predominantly a two-party system, the Jamaica Labor Party (J.L.P.) and the Peoples' National Party (P.N.P.). These two major political parties have exchanged control in the governance of

'CIA, "Jamaica," The World Factbook, 2002.

${ }^{2}$ Morris, 15 . 
the country several times since Independence. The Peoples' National Party (P.N.P.) has been in control of the government since 1989.

In 2001 the literacy rate of the total population was about 85 percent- 80.8 percent male and 89.1 percent female. ${ }^{1}$ In 2002 , the life expectancy for men was 73.65 years and women $77.73 .^{2}$ The infant mortality rate is estimated at 13.71 deaths for every 1,000 infants. ${ }^{3}$

During the period of the Spanish rule, Roman Catholicism was introduced. The Catholic Church was the first religious organization to enter the island. After the British took over in 1655 , the Anglican Church sent missionaries to Jamaica to establish the state religion of England. The Moravian church was the first Protestant Missionary Society to begin work among Jamaicans in 1754. Then came the Wesleyan Missionaries in 1789 and, shortly after, the Baptists followed. The first group of Presbyterians arrived in Jamaica in 1823 and the Congregationalists followed in $1834 .{ }^{4}$ Fernando Henriques points out that by 1834 , the year of emancipation, proselytizing had reached a considerable peak, which was further intensified in the subsequent years. Freedom to profess any type of religion

'Patrick Johnstone, Jason Mandryk, and Robyn Johnstone, Operation World: $21^{\text {st }}$ Century Edition (Waynesboro, GA: Paternoster Publishing, 2001), 386.

${ }^{2}$ CIA, "Jamaica," in The World Factbook, 2002.

${ }^{3}$ Ibid.

${ }^{4}$ Clifford Adolphus Furgerson, "Origin and Growth of Seventh-day Adventist in East Jamaica Conference," A Paper Presented for CHIS570, History of the Seventh-day Adventist Church, Andrews University, Winter 1977, 10. 
led to a display of intense fervor, marked by the immense size of congregations and an epidemic of church building. ${ }^{1}$

In Jamaica today, it is said that there are more churches per square mile than anywhere in the world. ${ }^{2}$ It is important to note that Protestant missionaries had been at work for more than half a century before the Seventh-day Adventist Church arrived in Jamaica. Bruce Flynn agrees with Merle Davis when she argues, "When Adventists came to Jamaica in 1892 , they had not come to an island of sinners. They came and found mature Christians, and this is one of the causes for the phenomenal growth of the Seventhday Adventist church in Jamaica."3

According to Johnstone, Mandryk, and Johnstone, the current statistics indicate that the population reflects 84.10 percent Christians, 10 percent Rastafarian/Spiritist, 0.30 percent Baha'i, 0.30 percent Chinese/Buddhist, 0.20 percent Muslim, 0.10 percent Jewish, and 5.00 percent non-religious/other. ${ }^{4}$

\section{The Development of Adventism in Jamaica}

The Seventh-day Adventist Church in Jamaica was organized in 1903. The population of Jamaica at that time was 756,000 . The membership of the SDA

'Fernando, 185.

${ }^{2}$ Morris, 12 .

${ }^{3}$ Bruce E. Flynn, "A Survey of the Development of the Seventh-day Adventist Work in West Jamaica," A paper presented for CHIS 570, History of the Seventh-day Adventist Church, Andrews University, May 1971, 8.

${ }^{4}$ Johnstone, Mandryk, and Johnstone, 368. 
church was between $1,200-1,888$ in seventeen churches, with three ordained ministers, and four ministerial licentiates. ${ }^{1}$ By 1995 the church had grown into three organized conferences with 535 churches. In all three conferences, there were ninety-three ordained ministers, and a membership of $162,831 .^{2}$

The Seventh-day Adventist Church in Jamaica has grown at such a phenomenal rate that in the year 2002 there were three organized conferences and one mission. The population in Jamaica is more than 2.6 million, the current SDA membership in Jamaica is 185,480 and there are approximately 555 churches. Furthermore there were 125 ordained ministers, one hospital, four health-care clinics, eight high schools, and one university. ${ }^{3}$ The ratio of Adventists to the population in the year 2002 was 1 per 14 persons. $^{4}$

The birth of the Seventh-day Adventist Church in Jamaica started out in a miraculous way. It began like a grain of mustard seed which was destined to send its roots of spiritual truth deep in the soils of the Caribbean and its branches spreading to the entire length and breadth of Jamaica. Linnette Mitchell describes the early beginning of

${ }^{1}$ Seventh-day Adventist Yearbook (Silver Spring, MD: Review and Herald Pub. Assn., 1995), 192-195.

${ }^{2}$ Ibid., 195.

${ }^{3}$ Seventh-day Adventist Yearbook, 2002, 174-175.

${ }^{4}$ General Conference of Seventh-day Adventists, Report of $57^{\text {th }}$ General Conference Session of Seventh-day Adventists, June 29-July 8, $2000,7$. 
Adventism as particularly interesting because it started in a relatively obscure and insignificant way. 1

According to Whitford Shaw, the humble beginnings of the Seventh-day Adventist work in Jamaica testifies to the effectiveness and spiritual productivity of the publishing work when it is executed properly. ${ }^{2}$ Ellen White recognized the importance of the publishing ministry when she stated; "If there is one work more important than another, it is that of our publications before the public thus leading them to search the Scriptures."

The small beginning of the Seventh-day Adventist Church was conceived in 1890 when a pioneer colporteur named William Arnold left from New York State and went to canvass on the small West Indian island of Antigua. While in Antigua, William Arnold sold a book entitled The King Is Coming to Henry Palmer, who was impressed with its contents and sent it to his son, James Palmer, in Kingston, Jamaica. ${ }^{4}$

James Palmer not only read the book but wrote to the International Tract Society for more published materials. When they arrived, he distributed them in the city of

'Linette Mitchell, The Light Is Come: A Short Story of the Seventh-day Adventist Church in Jamaica (Kingston, Jamaica: Linette Mitchell, 1990), 17.

${ }^{2}$ Whitford A. Shaw, "History of the S.D.A. Work in Jamaica Between 1893-1903," A paper presented for CHIS570 History of the Seventh-day Adventist Church, Andrews University, Spring 1978, 3.

${ }^{3}$ White, Testimonies to the Churches, 9:390.

${ }^{4}$ Mitchell, 18. William Arnold worked with the first group of SDA missionaries to Australia in 1885 . He was able to donate $\$ 1,500$ to the Adventist work which purchased the first printing press in Australia. 
Kingston. ${ }^{1}$ Palmer gave some of the tracts to one Dr. Ross, who worked at the Kingston Public Hospital (K.P.H.). Dr. Ross was not a religious person. He was not interested in reading the literature; so he gave the papers along with a booklet on the Sabbath to a social worker at the hospital by the name of Margaret Harrison. ${ }^{2}$

A Jamaican of English descent, Harrison read the publications and became interested and influenced five other families. These members became the first Sabbathkeeping company in Jamaica. ${ }^{3}$ In 1893 , Mrs. Harrison visited Battle Greek for medical treatment. During her visit at the General Conference session, she appealed to the leaders to send missionaries to Jamaica. In a positive response to her request, A. J. Haysmer and his family became the first official missionaries to Jamaica. ${ }^{4}$

Landing in Kingston on May 1893, the Haysmers found the six adherents waiting to welcome them. ${ }^{5}$ It was a joy seeing Mrs. Margaret Harrison again. The Haysmers were God's answer to their prayers that He would send for their growing church. As they assembled on Sabbath, May 27, 1893, expecting to find twenty members as was reported, the Haysmers were disappointed when only six members showed up. However, A. J.

${ }^{1}$ Ibid.

${ }^{2}$ Ibid., 18-19.

${ }^{3}$ Ibid., 19.

${ }^{4}$ A. J. Haysmer, "West Indies," Review and Herald, December 5, 1893, 766.

${ }^{5}$ Ibid. 
Haysmer was a man of action. He immediately started to plan for the advancement of the "work" in Jamaica.

Haysmer's plans included public evangelism as well as personal. It was reported that he rented part of Sister Harrison's house and set up the dining room, a space $10 \times 15$ feet, to conduct the meetings. The place soon became too small, making it necessary to move to a larger room. The new hall had a seating capacity of 175 people. Haysmer was extremely encouraged by the interest the "message" generated and he was encouraged that the congregation had doubled since they moved. "Nine more souls have taken their stand here in Kingston and many more deeply interested."2 The following year, 1894, the first SDA church was organized with thirty-seven members with membership increasing to 102 by $1895 .^{3}$

As a result of the aggressive missionary activities on the part of those who accepted the Adventist message, the membership continued to increase so that by 1896 there were more than three hundred Seventh-day Adventist believers on the island of Jamaica. Among the converts were ministers of other denominations. Some of these were instrumental in

'Haysmer, "West Indies," August 10, 1895, 539.

${ }^{2}$ Ibid.

${ }^{3}$ Seventh-day Adventist Encyclopedia (Washington, DC: Review and Herald Publishing Association, 1966), 695. 
bringing their entire congregations with them. They also influenced other prominent people to become members and outstanding workers in their new church. ${ }^{1}$

On November 5-15, 1897, the first general assembly of workers for the West Indies was held in Kingston. In 1903 the West Indies Mission was organized with its headquarters in Kingston, Jamaica. The number of Adventist believers reached 1,200 in that same year. ${ }^{2}$

\title{
Adventism Goes to Trelawny
}

Endeavoring to take the gospel to the length and breath of Jamaica, Haysmer traveled to Falmouth in Trelawny, about one hundred miles northwest of Kingston. At Falmouth he spent twelve days and conducted thirteen open-air meetings, resulting in four persons making their decision for Jesus, one a Wesleyan Methodist leader. ${ }^{3}$ Haysmer expanded his evangelistic outreach to include visiting in non-Adventist homes. On November 1, 1893, he preached at the Blue Mountain Baptist Church and started giving Bible studies to a Baptist pastor.

\author{
'Furgerson, 10-11. \\ ${ }^{2} \mathrm{Ibid}$. \\ ${ }^{3}$ Haysmer, "West Indies," August 10, 1895, 539.
}




\section{Adventism Goes from Trelawny to Spanish Town}

In Spanish Town, the former capital of the island, Haysmer was invited to speak for the Wesleyan minister. The Parochial Board, now called the Municipal Office, asked Haysmer to preach on the subject of temperance. At the end of the presentation, he was invited by the Wesleyan minister of the town to speak at his church. For months this was Haysmer's pattern of activities: public evangelistic meetings, preaching in non-Adventist churches, and visitations. One of Haysmer's first ministerial converts was Elder H. F. Humphrey, the pastor of an independent Baptist Church. ${ }^{1}$ Immediately, Humphrey joined forces with Haysmer and together they preached the Adventist message.

\section{Adventism Moves to Hanover}

It is difficult to present a chronological order of the work of Adventism in the West Jamaica Conference. In a report sent to the Review and Herald, September 1896, A. J. Haysmer reported that he answered a call to spread the gospel in Hanover. ${ }^{2}$ Haysmer documented this visit in his own words:

At Lucy a little company has received the message through the canvassers. I spent five days there and baptized five persons. I found them well educated in all points of the faith. I see no reason why a good company cannot be raised up there. How I longed to stay and break to them the bread of life, but duty calls me elsewhere. At this place,

${ }^{1}$ Shaw, 5-6.

${ }^{2}$ Flynn, 4 . 
as well as Browns' Town and Trinityville, land is ready to be given as soon as a chapel can be erected. ${ }^{1}$

\section{Adventism Goes to Westmoreland}

According to an article in the Review and Herald, October 12, 1897, Haysmer

and Humphrey went to Darliston in Westmoreland where they faced strong opposition.

This is how Humphrey described the area:

A place deluged in fanaticism and superstition, where opponents of the truth are numerous, strong and determined. They are the Episcopalians, Moravians, Revivalists, Salvationists, and the New Faith, (a sect of the Plymouth Brethren). These all put forth strenuous efforts to hinder the truth and the spread of the gospel. However, by hard and careful labor in house to house visits, Bible readings and open air preaching, twenty-five persons to the best of my knowledge are keeping the Sabbath. ${ }^{2}$

\section{Adventism Goes to St. Elizabeth}

In 1897 a member of the Salvation Army in Southfield in the parish of St. Elizabeth was sent to their headquarters in Kingston for training. While in Kingston, she accepted the Seventh-day Adventist message. On her return to Southfield, one Mr. Tennant, a captain in the Salvation Army, and about forty of his members became interested in Adventist teachings.

A request was made for a worker to be sent to Southfield. Elder W. Eastman, who had recently arrived from the Cayman Islands, was sent to conduct a crusade. $\mathrm{He}$ was assisted by the son of an Elder Kennedy, an Anglican clergyman who had recently
1'A. J. Haysmer, “West Indies," Review and Herald, September 29, 1896, 170.
${ }^{2}$ J. H. Humphrey, "Jamaica," Review and Herald, October 12, 1897, 650. 
accepted the "message" in Manchester. Many souls were won and soon a church was erected. Among the coverts was Mrs. Ira Parchment whose seven children later became workers in the SDA organization. ${ }^{1}$

\section{Adventism Goes to St. James}

In May 1903, Adventism entered Montego Bay. J. A. Strickland, along with two of his traveling companions, Brothers Beckner and Liston, came to Montego Bay and pitched a tent on a Sunday night. Two hundred and fifty persons attended that night and they had to request a $20 \times 30$ tent to accommodate the large crowd. These men labored under difficult circumstances. They encountered fierce opposition. During the meetings, they were told that their voices would be silenced. However, God blessed their efforts and 16 precious souls were baptized and a lady gave a plot of land on which to build a church. ${ }^{2}$

Six miles out of Montego Bay, Strickland went to Orange where the "work" started to grow. From Orange, Strickland traveled to Mt. Cary. This is what he reported:

On Sabbath, December 17, I mounted my bicycle to go to Mt. Cary eight miles into the mountains, arriving 10 o'clock. An earnest growing company is pressing forward in faith and much prayer. Sunday I buried seven precious souls. Seven services were held with the Mt. Cary brethren. Very large crowds were present at each evening meetings and indications were that the Spirit of God had impress with the importance and truth of the message. ${ }^{3}$

${ }^{1}$ Mitchell, 20-21.

${ }^{2}$ J. A. Strickland, “The Fieldwork: Northwestern Jamaica," Review and Herald, January 21, 1904, 17.

${ }^{3}$ Ibid. 


\section{The Organization of the West Jamaica Conference}

In 1919 , there were 2,200 members in fifty churches in Jamaica. In 1923 the Cayman Islands became a part of the Jamaican Conference. By the end of 1943, the membership of the Jamaica Conference had grown to 9,255 and 150 churches. This rapid increase in membership made it necessary to reorganize the conference. From a humble beginning, the growth of Adventism became phenomenal.

In 1944, the British West Indies Union came into being with its headquarters in Mandeville, Jamaica. Elder R. H. Pierson became the first president. The British West Indies Union, which had 10,000 members, was further divided into constituencies: East Jamaica and West Jamaica Mission. ${ }^{1}$ Elder D. U. Bond was elected the first president of East Jamaica Mission and Elder E. E. Parchment became the first president of West Jamaica Mission. ${ }^{2}$

By 1962, the membership had grown to 14,789 in the East Jamaica Mission along with another 16,000 in West Jamaica. This resulted in the organization of three conferences: East, West, and Central Jamaica Conferences. Elder Hiram S. Walters was elected the first president of the newly formed East Jamaica Conference. ${ }^{3}$ The dramatic growth continued, and the new North Jamaica Mission was organized in August 2002, with

${ }^{1}$ Mitchell, 20-21.

${ }^{2}$ Tbid., 77.

${ }^{3}$ Ibid. 
eighteen pastoral districts and its headquarters in St. Anns Bay. Pastor J. Smith was elected the first president of the Mission. ${ }^{1}$ See table 1.

\section{TABLE 1}

\section{ORGANIZATION OF JAMAICA CONFERENCES IN WEST INDIES UNION}

\begin{tabular}{|l|l|}
\hline Year Established & Conferences/Mission \\
\hline 1962 & East Jamaica \\
\hline 1962 & West Jamaica \\
\hline 1962 & Central Jamaica \\
\hline 2002 & North Jamaica Mission \\
\hline
\end{tabular}

\section{The Growth of the West Jamaica Conference}

In 1962, the West Jamaica Conference, located in the county of Cornwall, was the largest of the three conferences in the West Indies Union of Seventh-day Adventists. It consisted of five parishes: St. James, St. Elizabeth, Hanover, Westmoreland, and Trelawny. At that time, the conference membership was approximately 12,000 with 100 organized churches and companies. There were only fifty workers with an annual budget of $\$ 100,000$ or $£ 50,000 .^{2}$

${ }^{1}$ Princess Lawes, "Welcome North Jamaica Mission," Visitor, Third Quarter 2002, 11.

${ }^{2}$ West Jamaica Conference of Seventh-day Adventists, "Report of the First Quadrennial Session," 3-7 July 2002, 7. 
During the following years, the conference experienced rapid growth. In 1976, the headquarters moved to the beautiful twenty-two-acre Catherine Hall property overlooking the Caribbean Sea to the west and Cornwall Regional Hospital to the east of Montego Bay. ${ }^{1}$ In 2002 at the $1^{\text {st }}$ Quadrennial Session, there were 230 congregations and 64,000 members, an increase of 400 percent. By then there were 162 workers: 29 ordained pastors, 17 licensed ministers, 57 credentialed missionaries, 54 licensed missionaries, and five others. ${ }^{2}$ Table 2 indicates the growth from 1962-2002.

TABLE 2

GROWTH FROM 1962-2002

\begin{tabular}{|l|c|c|}
\hline & 1962 & 2002 \\
\hline Membership & 12,000 & 64,000 \\
\hline Workers & 30 & 162 \\
\hline Congregations & 100 & 230 \\
\hline Annual Budget & $\$ 100,000$ & $\$ 216,000,000$ \\
\hline
\end{tabular}

During the ninety-nine years of its existence, the SDA church grew at an incredible rate throughout the country. Jamaica's population in 2002 was more than 2.6 million. In addition to the West Jamaica Conference with its 64,000 members, the East Jamaica

${ }^{1}$ Mitchell, 77.

${ }^{2}$ West Jamaica Conference, 6. 
Conference had 120 churches and 55,062 members. In Central Jamaica Conference there were 234 churches and 68,560 members. ${ }^{1}$

The transfer of the Trelawny parish to the new mission leaves the West Jamaica Conference with the challenge of increasing the membership in the remaining parishes. It then creates an opportunity for the implementation of the strategies for equipping the laity for ministry.

${ }^{1}$ The Seventh-day Adventist Year Book (2002), 174-176. 


\section{CHAPTER 3}

\section{BIBLICAL AND THEOLOGICAL FOUNDATIONS FOR EQUIPPING THE LAITY}

This chapter examines the biblical and theological foundations for equipping the laity. It focuses on the equipping strategies of Moses in the Old Testament, Jesus, and the early church in the New Testament. Furthermore, it relates to insights of equipping during the time of Ellen White and early Adventism.

\section{The Equipping Strategies of Moses}

Every pastor can learn a significant lesson from the equipping strategy of Moses. At the beginning of his outstanding leadership career, Moses acknowledged that he had been called by God to lead the Israelites. He thought he understood his role until his fatherin-law pointed out that he needed an expanded model. Instead of equipping the leaders, Moses was following an authoritarian style of leadership. He played the role of judge, prosecutor, defense, and juror. It was a hierarchal model. Moses was doing everything and he was making all the decisions. Russell Burrill states:

Moses had reverted to the pyramid style of leadership with which he had grown up in Egypt. As a result, Moses was exhausted and had no time for his family, and the people were not in community with each other or with God. Moses was spending time settling disputes among the people. He was acting like many pastors today who 
spend all their time ministering to the people, caring for them and creating a total pastordependent church. ${ }^{1}$

Moses had a "wake-up call" during this formative stage of his leadership tenure.

Jethro immediately voiced his concern to Moses: "What you are doing is not good. You and these people who come to you will only wear you out. The work is too heavy for you. You cannot handle it alone" (Exod 18:17-18). Melvin J. Steinbron asked this pertinent question, "Can the pastor do it alone?" He points out that the traditional way of one person trying to minister to all people is inadequate. ${ }^{2}$ Moses adjusted his leadership style and delegated authority throughout the camp. Exod 18 identifies the way in which the leadership was divided. This model of leadership where the leader equips the laity to lead works in today's church.

The need to empower leaders from among the laity, giving away the ministry, has been the subject of much research. Two SDA pastors studied the barriers that affect the growth patterns in the SDA Church and they came to the startling conclusion that the greatest barrier to empowering lay leaders lies with the pastor. One pastor even confessed that his personal growth in the area of empowering others was the greatest barrier to his congregation. ${ }^{3}$ Under the theocracy, Moses received instruction from God and then passed

'Russell C. Burrill, Rediscovering an Adventist Approach to the Life and Mission of the Local Church (Fallbrook, CA: Hart Research Center, 1998), 105.

${ }^{2}$ Melvin J. Steinbron, Can the Pastor Do It Alone?: A Model for Preparing Lay People for Lay Pastoring (Ventura, CA: Regal Books, 1987), 42.

${ }^{3}$ John Grys and Greg Schaller, "Growing a Healthy Church," Ministry, March 2001, 11. 
it down to the people. Moses and God developed a relationship. Moses even argued with God. Later in the Old Testament, God invited the people to come and reason together with Him (Isa 1:18). In the experience of Moses, it is important to consider the shift in the authoritarian to shared leadership.

Leadership guru George Barna studied the role and expectations of twelve Protestant churches toward their pastor/leader. The conclusion of his study is revealing. Barna found out that many churches are making a grave mistake. They expect their pastor to be the master of all trades. The expectation set for most pastors dooms them to failure before they begin their work. These unrealistic expectations help to explain why pastoral burnout has grown to dangerous proportions. ${ }^{1}$

\section{Moses Trained a Successor}

The death of Moses would have created a leadership vacuum had he not prepared a successor (Josh 1:1). Interestingly, the Lord did not wait for Moses to die before the Lord commanded Moses to train Joshua to carry the mantle. Moses enlisted Joshua in the training camp of Israel. He was among the twelve leaders who went to explore the land of Canaan (Num 13:16). In spite of the negative account given by the ten leaders, Joshua's report was extremely positive. "We should go up and take possession of the land, for we can certainly do it" (Num 13:30).

'George Barna, The Habits of Highly Effective Churches (Ventura, CA: Regal Books, 1999), 37. 
Joshua had shared the confidence of Moses. They had worked side by side with each other and it seemed appropriate that Joshua should assume command. Nolan Harmon comments on the importance of training other leaders in order to carry the task. He states that when a leader falls, people are apt to sink into frustration, despair, and indifference. But, in God's economy there is always a leader who can carry the torch into the night and lead the people to their objectives. ${ }^{1}$ The $S D A$ Bible Commentary expresses the view that God's plan is never dependent on one person alone. When Moses died, God had a Joshua ready. ${ }^{2}$

Joshua defeated Jericho (Josh 6:2). He commanded the sun to stand still (Josh 10:12-14). In his old age Joshua was not satisfied with mediocrity, for there was more land to take (Josh 13:1). The tremendous success of Joshua must be credited to the early training of an outstanding leader called Moses. In the class, Equipping Lay Leaders for Ministry, Dr. Ricardo Norton's words are poignant: "Success without a successor is no success at all."

'Nolan B. Harmon, ed., The Interpreter's Bible, vol. 5 (Nashville, TN: Abingdon Press, 1953), 554.

${ }^{2}$ Francis D. Nichol, ed., The Seventh-day Adventist Bible Commentary, vol. 2 (Washington, DC: Review and Herald Publishing Association, 1976), 175.

${ }^{3}$ Class notes for Equipping Lay Leaders for Ministry, Andrews University, April 2000. 


\section{Insights of Equipping from Jesus}

One of the qualifications of a good leader is that he/she leads by example. People learn better by what they experience. It has been said that one forgets what is said, and acknowledges what is seen, but understands what involves them. Jesus demonstrated exemplary leadership by training, equipping, and empowering His disciples to carry on the work of the gospel.

Neal F. McBride identifies seven reasons why Jesus invested in that small group of twelve disciples. There are three reasons which stand out above the rest:

1. The small group was Jesus' method of leadership training. He devoted Himself primarily to the task of developing a select group of men, the apostles. His goal was to equip this small group of disciples to carry on the work of the gospel after He returned to His Father.

2. Jesus wanted a small group so that He could spent the majority of His time with them. They were constantly together, traveling, eating, experiencing mutual hardship, and literally living together.

3. Jesus as a small group leader showed that relationships, not organizations, were central to His method. ${ }^{1}$

'Neal F. McBride, How to Lead a Small Group (Colorado Springs: NavPress, 1992), $15-16$. 
Al McClure, a former president of the North American Division, states that the average Adventist church in North America spends only 5 percent of its budget on evangelism to the community, but 30 percent of its budget on buildings and maintenance. ${ }^{1}$ Jesus gave little, if any, time and attention to building an earthly organization. Jesus gave the disciples no elaborate scheme, no organizational charts. He simply organized and trained a small group. Jesus was concerned with building people. Building relationships, teaching, counseling, exhorting, empowering, and sending out missionaries was the essence of His ministry. Even though building structures for places of worship is essential, His primary mission was to share the gospel and build a body of workers.

\section{Definition of a Disciple}

The Greek word for "disciple" is mathetiuo, which means a follower or a learner. ${ }^{2}$ A leading expositor of church growth principles, Donald McGavran argues that not until a new believer is linked to the body of Christ, formed into fellowship with other believers, and responsibly ministering for others, can he or she be called a disciple. ${ }^{3}$ In his book, Bridges of God, McGavran develops the concept of a "disciple" which is defined in three stages:

1. Coming to Christ

\footnotetext{
${ }^{1}$ Alfred C. McClure, "Planting and Harvesting," Adventist Review, December 1996, 11.

${ }^{2}$ James A. Cress, You Can Keep Them If You Care (Oshawa, Ontario, Canada: Maracle Press, 2000), 13.

${ }^{3}$ Donald McGavran, Understanding Church Growth Principles (Grand Rapids, MI: Eerdmans, 1980), 74.
} 
2. Incorporation into the life of the church

3. Teaching others what you know about the Bible. ${ }^{1}$

Allen Hadidan explains that a disciple is a person who commits himself/herself for an extended period of time to a few individuals who have been won to Christ, the purpose being to aid and guide their growth so that they can be equipped to reproduce themselves in a third generation. ${ }^{2}$

The concept of making disciples has been misunderstood, says Oscar Thompson. He argues that the command to "make disciples" gets translated into "go and teach and baptize" without remembering that it is not just the "going" but the follow-up teaching, the making of disciples, that is the central theme. ${ }^{3}$

\section{Discipleship in the Time of Jesus}

Who were these disciples whom Jesus trained and what lessons can we learn in order to make disciples today? What was the concept of discipleship during the time of Christ? Aaron Milavec has conducted extensive research on discipleship during the time of Christ. He presents valuable insights into the way a disciple relates to his master. Milavec points out that neither Jesus nor any of the Pharisees left private journals, nor did any of the

${ }^{1}$ Cress, 13-14.

${ }^{2}$ Allen Hadidan, Discipleship: Helping Other Christians Grow (Chicago, IL: Moody Press, 1987), 11.

${ }^{3}$ Oscar W. Thompson, Jr., Concentric Circle of Concern (Nashville: Broadman, 1981), 156. 
disciples use notebooks to record their sessions with their Master. However, a well-trained disciple could be relied upon to accurately and faithfully present the deepest concern and patterns of judgment that were exhibited by his master. ${ }^{1}$

To accomplish this, the disciples did not act as a modern press reporter who observes and probes his subject. Nor did the disciple give himself faithfully to memorizing and repeating meticulously the collected discourses of his master. The disciples entered much more intimately with him. He roomed and roamed with him. He learned his moods, his passions, his sorrows. He learned how to unlace his sandals and how to lace them up again. Out of this experience, the disciple later spoke of his master as a long-time companion and his "father," the one who shaped my life.

Jeffrey Arnold resonates with the concept of discipleship during the first century. He states that a disciple during the time of Jesus was usually a student of a particular teacher, an apprentice who learned all their master could teach so that they could go and become masters themselves. ${ }^{3}$ The relationship was so close that it involved breaking off from one's family life and one's former occupation. An apprenticeship in the Torah required that the disciples live with their master. Matthew recorded how the disciples left

'Aaron Milavec, To Empower as Jesus Did: Acquiring Spiritual Power Through Apprenticeship (New York: Edwin Press, 1982), 105-106.

${ }^{2}$ Ibid., 106.

${ }^{3}$ Jeffrey Arnold, The Big Book on Small Groups (Downers Grove, IL: InterVarsity Press, 1992), 15. 
their parents in order to be with Jesus. The relationship Jesus developed with them was so personal that He regarded them even closer than His immediate family (Matt 12:46-50).

\section{Jesus' Call to His Disciples}

At the beginning of Jesus' ministry, Matthew records that He approached two pairs of fishermen and invited them to "follow me" (2:18; 4:21-22). Interestingly, the same word "follow me" was used when Jesus approached Matthew (9:9). The biblical account states that these fisherman left their present career and followed Jesus.

Laurie Beth Jones is fascinated by the way Jesus began His work. He wasted no time in forming a team. People were inexplicably drawn to Him and He to them. "Follow me," He called out across the water, and without hesitation they followed Him. Jesus knew that He alone could not change the world. ${ }^{1}$ More importantly, however, as Milavec argues, Matthews wants his readers to understand that Jesus was now taking a new identity--that of master (didaskalos) whose energies are directed towards apprenticing disciples (machetes). ${ }^{2}$

These words, "Follow me," are not really as simple as an English reader of the gospel might consider. A careful linguistic study reveals that these words were a Jewish idiom which was meant to be taken very seriously. ${ }^{3}$ It is interesting to note that even though

${ }^{1}$ Laurie Beth Jones, Jesus CEO: Using Ancient Wisdom for Visionary Leadership (New York: Laurie Beth Jones, 1995), 90.

${ }^{2}$ Milavec, 107.

${ }^{3}$ Ibid., 108. 
Jesus uses a term that was significant then, He was establishing a new set of roles in the way He selected His disciples. First, this new order would distinguish Him from the former prophets who kept their divine calling to themselves. Jesus' order of selection was not exclusive, it is one that can and should be shared. Second, Jesus was also establishing a distinction between Himself and the Pharisaical masters.

In the synagogues the residents not only taught basic reading and interpretation of the Scripture, but also they taught the art and practice of holiness which they, in turn, had received from their masters before them. A tradition of holiness and service was thus sustained and passed down by virtue of each master thoroughly apprenticing a few disciples. ${ }^{1}$

\section{The Training of Jesus' Disciples}

One of the fundamental reasons why Jesus called the twelve disciples was to train them for service. It was extremely significant that Jesus selected twelve disciples as His small group at the beginning of His career. Sociologists argue that in any group which grows larger than twelve it is very difficult to maintain discussion and interaction. ${ }^{2}$ Whenever a group is more than twelve it is better to divide it into two groups.

'Tbid., 110.

${ }^{2}$ Kurt W. Johnson, Small Groups for the End-time (Hagerstown, MD: Review and Herald Pub. Assn., 1997), 51. 
Among the twelve was an inner circle, Peter, James, and John, with whom Jesus shared a special relationship. Kurt Johnson points out that there is nothing wrong with group members bonding with one another. Encouraging close friendship and prayer partners among various members will assist the group in ministering to one another and strengthens the group. ${ }^{1}$

Jesus recognized the importance of training the disciples to develop their leadership abilities. Their concept of leadership was exactly opposite to Jesus. These disciples were disputing among themselves for the highest place in the kingdom (Luke 22:24-27). They were concerned with power and control instead of service and ministry.

Russell Burrill confirms that Jesus spent time with the disciples so that they could develop ministry among themselves. They did not trust each other. They were not open and vulnerable to each other, instead they were judgmental. ${ }^{2}$ Christian Schwarz refers to these kinds of leaders as authoritarian, project- or goal-oriented. Churches fail to grow because these leaders do very little to equip and empower the members to get involved in ministry. ${ }^{3}$

Jesus had to teach the disciples that leadership does not mean to be served but to serve, to follow in order to lead, to be humble in order to be great. William Easum

${ }^{1}$ Ibid., 52.

${ }^{2}$ Russell Burrill, Revolution in the Church: Unleashing the Awesome Power of the Lay Ministry (Fallbrook, CA: Hart Research Center, 1993), 108.

${ }^{3}$ Christian A. Schwarz, Natural Church Development (Emmelsbull, Germany: C \& P Publishing, 1998), 22-23. 
describes Jesus' kind of leadership as "Permission-Giving Leaders." These are leaders who do not give orders or dictate how people operate, but are part of a team and leader of the team. Their passion is to develop other leaders who will develop other leaders. ${ }^{1}$

Jesus Equipped His Disciples by Training Them

Practical experience is an integral part of training. Jesus not only imparted theoretical knowledge to His disciples but practical training as well. James Cress emphasizes the importance of balancing theory and practice:

If the dissemination of information alone were sufficient to accomplish conversion, then Seventh-day Adventists, of all people, ought to be spiritual giants. Adventists prize the truth. In fact, love of theological correctness has been historically expressed with this very phrase--"the truth"--to describe the entire sub-cultural phenomenon of the Seventh-day Adventist church. Our pride in theological accuracy and orthodox, combined with a distinctively conservative lifestyle (scrupulous observance of Sabbath, no alcohol, tobacco, or "unclean" foods if not outright vegetarianism, no theater, movies, novels, dancing, limited jewelry or make up, limited extravagance possible when a distinctly high percentage of income is given to the church or utilized in educating children in parochial schools from preschool to university, etc.) has often produced a closed society into which we ostensibly welcome new believers but, practically, make it difficult to join. Instead of being scattered throughout the nonChristian community as salt and light, becomes isolated from it as distinct cultural entity on its own. ${ }^{2}$

Jesus sent the disciples out there into the world in order for them to obtain practical training (Matt 10:1). He also selected seventy-two and sent them out two by two into the towns and villages (Luke 10:1). McGavran and Arn resonate with John Stott when he

${ }^{1}$ William M. Easum, Sacred Cows Makes Gourmet Burgers (Nashville: Abington Press, 1995), 72.

${ }^{2}$ Cress, $47-48$. 
argues that conversion must not take the convert out of the world but rather send him back into it, the same person in the same world, and yet a new person with new convictions and new standards. ${ }^{\prime}$ These disciples were not to live in a vacuum. They were not to minister alone. Jesus sent them out in pairs, two by two, for only in communities can other communities be created.

Christ was concerned about building relationships so He sent out the disciples two by two. Ellen White affirms that Christ's method is best and it will always result in a loss to follow other methods than His. ${ }^{2}$ Carl George is quick to point out that many Christians have accepted an absolutely foolish notion that a person can be lectured into leadership. Leadership formation cannot occur without on-the-job coaching by someone to whom the leadership trainee is willing to be responsible. ${ }^{3}$

Theory without practice means very little. Research indicates that after thirty days people remember 10 percent of what they heard, 50 percent of what they see, 70 percent of what they say, and 90 percent of what they do. ${ }^{4}$

Palmer Becker provides a four-step conceptual framework for training disciples:

'Donald A. McGavran and Win C. Arn, Ten Steps for Church Growth (New York: Harper and Row, 1977), 121.

${ }^{2}$ Ellen G. White, "Seek First the Kingdom of God," Review and Herald, January 31, 1893,65 .

${ }^{3}$ Carl George, The Coming Church Revolution: Equipping Leaders for the Future (Grand Rapids, MI: Fleming H. Revell, 2000), 135.

${ }^{4}$ Palmer Becker, Called to Equip: A Training and Resource Manual for Pastors (Scottsdale, PA: Herald Press, 1993), 47. 
Step 1: "I do, you watch."

Step 2: "I do, you assist."

Step 3: "You do, I assist."

Step 4: "You do, I watch."”

In his book, Bill Hull identifies a process that Jesus used to equip His disciples.

First, Jesus invited the disciples to "come and see" what He is like (John 1:38-39). Second, Jesus asked them to follow Him (Mark 1:16-39). Third, Jesus called the Twelve to "be with Him"as workers (Matt 9:37, 38). Finally, Jesus promised them great blessing to "remain in Him" (John 15:7, 8). ${ }^{2}$ This process of discipleship began when Jesus invited the disciples to get acquainted with Him and continued as Jesus led them to deeper levels of commitment.

Making disciples is not a destination, it is a journey. It is not an event, it is a process. The question that every pastor and leader must ask is, Is the church making disciples? Jesus' method of making disciples was totally different from the Pharisees. They were concerned about controlling power. Jesus gave it away to His disciples. He developed an intimate relationship with the disciples, equipping and empowering them, and sent them out two by two to minister and create communities. The disciples were a small group but they made a profound impact on people' lives.

'Tbid., 48.

${ }^{2}$ Bill Hull, Jesus Christ, Disciple Maker (Old Tappan, NJ: Fleming H. Revell Company, 1990), 225. 


\section{Equipping in the Early Church}

Jesus is one of the greatest exponents of small groups, even though He never commanded the church to have small groups. However, throughout His ministry $\mathrm{He}$ demonstrated the development of community as a primary objective. ${ }^{1}$ People are tired of preventions and lectures and are longing for personal relationships. ${ }^{2}$ Jesus not only called Matthew, but spent time with him by eating at his house. Furthermore, Jesus took the disciples along with Him while He performed ministry, then He gave them authority to do the job (Matt 9-10).

Jesus gave His staffers authority even before they seemed ready for it. Laurie Beth Jones states that some people are given a plan but are never given the authority to implement the plan. These are plans that are destined to die in committee. Delegation of authority requires a tremendous amount of trust. Any leader who does not delegate will end up with a group of "yes people," which will eventually lead to his or her own demise. ${ }^{3}$

The foundation was laid. Jesus trained the disciples to work and develop relationships with people and automatically they would model their Master's example. At

'Arnold, 73-74.

${ }^{2}$ Tom Clegg and Warren Bird, Lost in America: How You and Your Church Impact the World Next Door (Loveland, CO: Group Pub., 2001), 66.

${ }^{3}$ Jones, 264-265. 
the very heart of the early church were small groups, and these played a significant role in the church's development and success. ${ }^{1}$

\section{The Early Church Faced Persecution}

One of the most difficult periods of the Christian Church came about during the first to the third centuries. The early church was severely persecuted, but in spite of the relentless and intense opposition, the church experienced phenomenal numerical and spiritual growth. During the first century, Nero, a first-century Roman Emperor, passed decrees and laws prohibiting any new movements and secret societies from building churches or convening in public. Violators of those laws would lose their property, Roman citizenship, and even their lives. ${ }^{2}$

Nero became a relentless persecutor. He set fire to Rome, perhaps to clear space for new building projects, and them blamed it on the Christians. He had animal skins sewn around Christians who refused to denounce their faith, and as cheering spectators watched, the martyrs were ripped to pieces by wild dogs. Nero's reputation as a persecutor was confirmed when he had Christian martyrs covered with oily tar and then set them on fire for his personal enjoyment. ${ }^{3}$

Emperor Trajan, who ruled between A.D. 98-117, had no sympathy for the Christians. He labelled them as a depraved and immoderate band of people. Domitian continued to persecute the Christians who met and worshiped together. ${ }^{4}$ Despite the

'McBride, 19.

${ }^{2}$ Johnson, 23.

${ }^{3}$ Ibid.

${ }^{4}$ Ibid. 
severe persecution that was meted out to the members of the early church, it could not quench the spreading of the gospel. Johnson quoted one of the early church fathers as saying, "The blood of the martyrs was the seed of the Christian church."1

Finally, the Roman Emperor Constantine brought persecution to a halt in A.D. 313 by making Christianity the official religion of the Roman Empire. It was at this time that the church's theology and practice began to shift regarding the role and function of the laity.

\section{Strategies Used in the Early Church}

The equipping strategy of the early church was very unique. In spite of the intense persecution that they experienced, the church did not surrender in despair. Believers developed an effective strategy that the apostles inherited from Jesus and the result was unprecedented. The book of Acts gives an insightful description into the life of the early believers.

They devoted themselves to the apostles teaching and to the fellowship, to the breaking of bread and to prayer. Everyone was filled with awe, and many wonders and miraculous signs were done by the apostles. All believers were together and had everything in common. Selling their possessions and goods, they gave to everyone as he had need. Every day they continued to meet together in the temple courts. They broke bread in their homes and ate together with glad and sincere hearts, praising God and enjoying the favor of all the people. And the Lord added to their number daily those who were being saved. (Acts 2:42-47, NIV)

${ }^{1}$ Ibid., 54. 


\section{Description of the Early Church}

Luke gives the earliest description of the early church. Believers met together daily in the temple courts and ate together in their homes with glad and sincere hearts (Acts $2: 46$ ). One might argue that the early believers had no choice but to meet in private homes because of persecution. Yet there is a larger issue here; these new believers were simply implementing a practice that Jesus established--a small-group, home-based church which was strategic in its particular context.

Andrew Clarke points out that it is certainly significant that the context for meetings of the early Christian communities was normally within the home. ${ }^{1}$ Many of these were large enough to accommodate thirty to thirty-five persons, while there were smaller homes which could accommodate ten to fifteen persons. ${ }^{2}$ As soon as the new believers were baptized, the church immediately incorporated them in ministry. The members devoted themselves to the apostles' teachings, to fellowship, to the breaking of bread, and to prayer (Acts 2:42, NIV).

Burrill's study on the early church and its small-group activities in building relationships is extremely enlightening. Bible study in a small-group setting encourages dialogue and interaction. Fellowship takes place as believers openly share their struggles

${ }^{1}$ Andrew D. Clarke, First Century Christians in the Greco-Roman World: Serve the Community of the Church (Grand Rapids, MI: Wm. B. Eerdmans Publishing Co., 2000), 160-161. 35.

${ }^{2}$ Robert Banks, Paul's Idea of Community (Boston: Hendrickson Publishers, 1995), 
and problems with each other. Eating together develops a bond between people, and prayer builds a strong spirituality. ${ }^{1}$

Pastors should not only heed the counsel of Ellen White, but implement it in the churches.

Let small companies assemble together in the evening or early morning to study the Bible for themselves. Let them have a season of prayer that they may be strengthened and enlightened and sanctified by the Holy Spirit. . . . If you are willing to do this, a great blessing will come to you from the One who gave Him life for service, the One who redeemed you by His own life. . . What testimonies you should bear of the loving acquaintance you have made with your fellow worker in those precious seasons when seeking the blessing of God. Let each tell his experience in simple words. . . Let little companies meet together to study the Scriptures. You will lose nothing by this, but will gain much. ${ }^{2}$

This is how some Christians live. They hide away from each other except for Sabbath. The rest of the week they are wrapped up in jobs, household duties, a church meeting once a while, and their own group of friends. They rarely have time for prayer meeting, weekly small group, individual Bible studies, friendship evangelism. or other ministry. Periodically when an announcement is made in church about an emergency need, they drop everything and help retreat back into their own cocoon. ${ }^{3}$

In a society where people are isolated from each other and there are so many "lone ranger" Christians, it is extremely difficult to build close relationships. Robert Frost says

${ }^{1}$ Burrill, Revolution in the Church, 114.

${ }^{2}$ Ellen White, This Day With God (Washington, DC: Review and Herald Pub. Assn., 1979), 11.

${ }^{3}$ Johnson, 16. 
"good fences make good neighbors." Studies reveal that approximately 80 percent of the church attendees in North America are consumers--they attend church once a week while the remaining 20 percent are involved in ministry weekly--the familiar $80 / 20$ rule. $^{2}$

Flavel Leakey, in his dissertation, found out that the more quickly new members formed a number of personal relationships within the congregation, the more likely they were to become involved. The converts who stayed had developed an average of more than seven new friends in the church. ${ }^{3}$ Church must be more than what happens one day a week. A church must go beyond its parking lot and become a loving community.

\section{Pauline Model of Equipping}

The apostle Paul was an outstanding leader, pastor, and evangelist. As an itinerant preacher, he was instrumental in planting many churches. Clearly there were other models of church organization that Paul could form. However, he used a model that Jesus and the early church had established. Paul was not a solo worker. He emulated Jesus' example by taking a partner with him on his missionary journey. Paul took along with him Barnabas and John Mark (Acts 13:1-5). At the beginning of the second missionary journey, after Paul's disagreement about taking John Mark, Paul's companion was Silas (Acts 15:40).

${ }^{1}$ Jones, 265.

${ }^{2}$ Johnson, 14 .

${ }^{3}$ Win Arn, "The Friendship Factor," in The Pastor's Church Growth Handbook (Pasadena, CA: Church Growth Press, 1979), 2:179. 
Later in his ministry Paul enlisted a young recruit called Timothy, his true son in the faith (1 Tim 1:1). Apparently Paul recognized the importance of training other leaders who could carry on the work. He placed a great emphasis on practical training. Timothy was one of those young leaders who received practical training from Paul. As they worked together Paul held him to the highest standard. He did not spare Timothy from the difficult experiences, neither was he sheltered from the hardships that would help him to cope with the challenges of ministry.

\section{Paul Equips House Churches During His Ministry}

Paul utilized various venues as a means of preaching the gospel, i.e., temple, synagogues, etc.; however, house churches played an integral part in his mission outpost. Some of the oikos churches were the homes of Mary, the mother of John Mark (Acts 12:12), the church in the house of Priscilla and Acquilla (Rom 16:3-5; 1 Cor 16:19), the church in the house of Philemon (Phlm 2), and the church in the home of Nympha (Col $4: 15)$.

Bill Hornsby has done an in-depth investigation into the early church. He discovered that the church has wielded immense influence through house-to-house ministry. ${ }^{1}$ Hornsby further observes, "There is a great return on any investment made in the 27.

'Bill Hornsby, The Cell Driven Church (Mansfield, PA: Kingdom Publishing, 2000), 
lives of people. People should always be our focus, as success begins and ends with people."1

Paul Yonggi Choi is the pastor of Yoido Full Gospel Church in Seoul, Korea. It is the largest church in the world, having a membership of 730,000 and involving more than 25,000 cell groups. Before the church experienced such phenomenal growth, Pastor Cho was doing everything. The result of his trying to do everything was devastating. He fainted many times while he was preaching and he suffered prolonged sickness for ten years.

During his illness Pastor Cho recognized that he must train the members for ministry. Despite opposition from the men, Cho equipped the women and sent them out to work for the Lord. Through circumstances, and no doubt prayer, he discovered a system of home groups and corresponding leadership training to lead Yoido Full Gospel to become the largest church in the history of Christendom. A total of 730,000 people regularly participate in home groups for Bible study and prayer. ${ }^{2}$

Paul was so much in love with these home-based churches that he referred to the new believers as a "household of faith" (Gal 6:10). They were members of the "household of God" (Eph 2:19). Since Christians were not allowed to build churches until A.D. 313, the home became the meeting place for early believers.

${ }^{1}$ Ibid.

${ }^{2}$ Paul Yonggi Cho, Successful Home Cell Groups (North Brunswick, NJ: BridgeLogos Publishers, 1999), 79-81. 


\section{Equipping the Church Through Spiritual Gifts}

Paul used vivid illustrations to explain how the members of the church should take care of each other. In Rom 12:4-5, Paul says that just as each of us has one body with many members and these members do not have all the same function, so in Christ we who are many form one body and each member belongs to all the others.

In Rom 12:6-8 Paul identifies various gifts and the way these gifts should be used for mutual care. In 1 Cor 12, he gives a more detailed analysis of the diversity of gifts, the source of the gifts, and their overall contribution to the whole. Paul metaphorically likens the church to the body of Christ. He warns that each part of the body, though insignificant, has an extremely vital part in its effective operation (1 Cor 12:12-17).

Delbert Baker emphasizes that in all the biblical depictions of the church, there is no suggestion of homogeneity or bland conformity. Rather, there is the opposite--great diversity, which is the very essence of the church. ${ }^{1}$ Ellen White did not emphasize uniformity, but unity in diversity. Here is how she expresses it:

There are not two leaves of a tree precisely alike, neither do all minds run in the same direction. But while this is so, there may be unity in diversity. . . Look at the flowers in a carpet, and notice the different color threads. All are not pink, all are not green, all are not blue. A variety of colors are woven together to perfect the pattern. So is it with the design of God. He has a purpose in placing us where we must learn to live as individuals. $^{2}$

'Delbert Baker, ed., Make Us One: Celebrating Spiritual Unity in the Midst of Diversity (Boise, ID: Pacific Press Pub. Assn., 1995), 22.

${ }^{2}$ Ellen G. White, "God's Design for His People," Review and Herald, July 5, 1899, 62. 
Everyone is valued because of what they can contribute to the good of the body of Christ. Only one thing is required of each person--loyalty to the Head, Jesus Christ. Christians are held together in the body by the Lordship of Jesus Christ. In a sense, Jesus infuses us with divine DNA. When people discover how God created them to function within the body, the church comes alive with ministry to people rather than going to endless rounds of meetings. ${ }^{1}$

New believers should be led to discover that which best fits their own capabilities and Spirit-given gifts. If new believers are "forced" into one mold of ministry they may become frustrated and potential souls may be lost to Christ's kingdom. ${ }^{2}$ Peter Wagner quotes Elizabeth O'Connor, "We ask to know the will of God without guessing that His will is written in our very beings. We perceive that will when we discern our gifts." ${ }^{3}$ Peter Wagner encourages every believer to discover, develop, and use their spiritual gifts which are not achieved but received. ${ }^{4}$ Schwarz clearly points out that when Christians serve in their area of giftedness, they generally function less in their own strength and more in the power of the Holy Spirit. ${ }^{5}$

${ }^{1}$ Easum, 63.

${ }^{2}$ Cress, 73 .

${ }^{3}$ C. Peter Wagner, Your Spiritual Gifts: How to Find Your Gifts and Use Them to Bless Others (Ventura, CA: Regal Books, 1994), 35-36.

${ }^{4}$ Ibid.

${ }^{5}$ Schwarz, 24. 


\section{Equipping the Church Through Training}

The text in Eph 4:11-13 is particularly captivating because it challenges every pastor to return to their job description--that of training the laity for ministry. Russell Burrill indicates that most modern translations correctly translate vs. 13 by omitting the comma after "saints," which squarely puts the role of the pastor as trainer in ministry. ${ }^{1}$ The New International Version supports Burrill's claim by its translation of vs. 13, "To prepare God's people for works of service."

This text in vs. 13 is a challenge to every pastor to equip the members for the ministry. Some church members see the pastor as the one who visits the sick and discouraged, gives Bible studies to the non-Christians, chairs meetings, manages the finances of the church, and preaches a sermon each week that meets the spiritual and emotional needs of the congregation. If a church elder or another member performs the ministry function, it is not the same. Unfortunately, some clergy have cautioned lay-people to avoid entering their domain. Performing ministry is not the prerogative of the clergy alone, but instead the rightful domain of all believers, which includes both clergy and laity. ${ }^{2}$ Burrill strongly feels that the artificiai distinction between the clergy and the laity must be eliminated. There is no difference in status between clergy and laity. We are on the same level. $^{3}$

'Burrill, Revolution in the Church, 27.

${ }^{2}$ bid., 30 .

${ }^{3}$ Ibid. 
Burrill briefly explains how the dichotomy came about between the clergy and the laity:

In the New Testament, the clergy were lay people who devoted full time to directing gospel work. The laity were seen as performers of ministry. Yet, as part of the laity, the clergy also performed ministry. As the church advanced into the Dark Ages, the clergy gradually elevated to a higher standing in the minds of the people, until eventually the priesthood developed and the role of the laity became limited to paying bills and observing the clergy perform their ministry. ${ }^{1}$

In today's modern church setting, the laity's role has been reduced to serving as spectators whose main religious function is to occupy a pew on Sabbath morning. As long as members show up on Sabbath morning, they are considered to be in good standing. ${ }^{2}$

There is no such thing as being a member of the church without also being a "minister" and a "missionary." Essentially the laymembers and the pastors do not belong to different categories. The distinction between clergy and laity on the basis of some special or supposed call or quality possessed by the latter, is not wholly proper. There are differences in function, but both are called and are responsible to do God's will and have a part in His work in the world. Both the clergy and the laity must work together in order to carry out the gospel commission. ${ }^{3}$ The call is even more urgent to make our church a lay-

${ }^{1}$ Ibid.

${ }^{2}$ Ibid.

${ }^{3}$ Cress, 72 . 
oriented church. ${ }^{1}$ Christian theology must no longer be simply a theology for priests and pastors, but also a theology for the laity in their calling in the world. ${ }^{2}$

\section{Ellen White's Counsel on the Role of Small Groups in Equipping the Laity for Ministry}

Of all the pioneers, the one who has made the greatest impact on the Seventh-day Adventist Church was Ellen Gould Harmon White, a twin born on November 26, 1827. SDAs believe that Ellen G. White was given the gift of prophecy. ${ }^{3}$ She spoke passionately about the role of the pastor in equipping the laity for ministry. Therefore, it is appropriate to examine her writings to discover her views concerning the pastor equipping the laity for ministry.

\section{The Influence of Methodism on Ellen White's Spiritual Life}

Many of the early believers who came into the Adventist Church were from various churches and some from no church at all. Joseph Bates and James White had been members of the Disciples or Christian Connexion Church. Ellen White and J. N. Andrews were Methodists before becoming Adventists. ${ }^{4}$ Ellen White was baptized into the Methodist Church in 1842. She described the event in these words:

'Burrill, Revolution in the Church, 30.

${ }^{2}$ David J. Bosch, Transforming Mission: Paradigm Shifts in Theology and Mission (Maryknoll, NY: Orbis Books, 1999), 467.

${ }^{3}$ Everett Dick, Founders of the Message (Washington, DC: Review and Herald Pub. Assn., 1938), 199.

${ }^{4}$ Ibid., 99. 
It was a windy day when we, twelve in number, went down into the sea to be baptized. The waves ran high and dashed upon the shore, but as I took up this heavy cross, my peace was like a river. When I rose from the water, my strength was nearly gone, for the power of the Lord rested upon me. I felt that henceforth I was not of this world, but had risen from the watery grave into a newness of life. The same day in the afternoon I was received into the church in full membership. ${ }^{1}$

As a member of the Methodist Church, Ellen White became involved in what were called small-group meetings. ${ }^{2}$ This practice originated in England and later developed into the Adventist's weekly prayer meetings. In order to understand these class meetings, it is important to go back to England in the nineteenth century and briefly review the role John Wesley and Whitefield played in the small-group movement. Wesley and Whitefield traveled to the English countryside calling people back to God. As individuals made their decision for God, they were organized into societies. These societies met together in rented facilities for prayer, Bible study, fellowship, and worship. ${ }^{3}$

D. Michael Henderson describes the open atmosphere at Wesley's class meeting:

Everyone here has equal liberty of speaking, there being no greater or less than another. I could say freely to these, when they were met together, "Ye may all prophesy one by one," (taking that word in its lowest sense), "that all may learn, and all may be comforted." As I after found the advantage of such a free conversation, and that "in the multitude of counselors there is safety." Any one is inclined so to do is likewise encouraged to pour out his soul to God. And here especially we have found, that " the effectual fervent prayer of a righteous man availeth much." ${ }^{\prime 4}$

'Ellen G. White, Life Sketches (Mountain View, CA: Pacific Press, 1915), 25.

${ }^{2}$ Ibid., 43.

${ }^{3}$ Johnson, 61 .

${ }^{4}$ D. Michael Henderson, John Wesley Class Meeting (Colorado Springs, CO: NavPress, 1995), 15. 
The small-group movement in Methodism had an impact an the SDA Church because of the influence of Ellen White. Early in her experience, Ellen White recognized the positive spiritual benefits of small-group ministry. She counseled the church to preach less and educate more by holding Bible readings and by praying with families and little companies. Ellen White further encourages the church to improve every opportunity by presenting Christ in the family, by the fireside and in small gatherings in private houses. This is often more successful in winning souls to Jesus than are sermons delivered in the open air, to the moving throng, or even in halls or churches. ${ }^{1}$

During the time that Ellen White spent in Australia, she also advocated the importance of small groups:

The formation of small companies as a basis of Christian effort is a plan that has been presented before me by the One who cannot err. If there is a large number in the church, let the members be formed into small companies, to work not only for the church members but for unbelievers. ${ }^{2}$

Ellen White also counseled pastors to return to their biblical role of equipping and training the laity for ministry. This is how strong Ellen White felt about the role of pastors to equip the members:

Let the minister devote more of his time to educating than to preaching. Let him teach the people how to give others the knowledge they had received. It is not the Lord's purpose that ministries should be left to do the greatest of the work of sowing seeds of truth. ... God has not given His ministers the work of setting the churches right. No 11.

${ }^{1}$ Ellen G. White, The Great Controversy (Mountain View, CA: Pacific Press, 1950),

${ }^{2}$ Ellen G. White, Evangelism (Washington, DC: Review and Herald Pub. Assn., 1948), 115. 
sooner is this work done apparently than it has to be done over again. Church member are thus looked after and labored for become religious weaklings. Sometimes members do too much, they seek to embrace the whole work in their arms. It absorbs and dwarfs them, yet they continue to work in the cause of God, while the members of the church stand idle. This is not God's order at all. So long as church members make no effort to give to others the help given them, great spiritual feebleness must result. ${ }^{1}$

One of the purposes of training new members is to equip them to become productive church members. Ellen White points out that Christ-loving, devoted members will do more good in a church than one hundred half-converted, unsanctified, self-sufficient workers. ${ }^{2}$ She also recommended that every member must be given a job assignment in the church. When church members put forth their earnest efforts to advance, they will live in the joy of the Lord and will meet with success. ${ }^{3}$

Ellen White specifically charged the pastors to be responsible in equipping the members of the church. Ministers should not be at all satisfied with their success until they can, by their earnest labors and the blessing of God, present to Him serviceable Christians who have a true sense of their responsibility and will do their appointed work. ${ }^{4}$

It is often the case that ministers are inclined to visit almost entirely among the church, and devote their time and strength where their labor will do no good. Frequently, the churches are in advance of the minister who labors among them, and would be in more

${ }^{1}$ White, Testimonies for the Church, 7:20, 21.

${ }^{2}$ Ibid., 5:114.

${ }^{3}$ Ibid., 7:30.

${ }^{4}$ White, Evangelism, 345. 
prosperous conditions if those ministers would keep out of their way and give them an opportunity to work.

The effort of such ministers to build up the churches only tears them down. Some churches would prosper more if their minister got out of the way and let them work.' Ellen White strongly believed that if pastors do not train and equip the members, but continue to perform ministry rather than teaching members to minister, they should be fired. ${ }^{2}$

\section{Equipping the Laity in Early Adventism}

The Seventh-day Adventist Church started out as a lay-driven, relationshiporiented movement. Ellen White was one of the early pioneers who organized and mobilized the laity for ministry. The model she used in equipping the laity for ministry was significant to the church in its early stages. After the Great Disappointment of October 22, 1844 , the mission of the church moved forward with a greater sense of urgency. The members, along with their pastors, sacrificed time and effort to take the gospel into all the world in preparation for the imminent return of Jesus.

The Adventist church historically began, as small groups coming together in what was called social meetings. The early Adventist social meeting was very similar to Methodist prayer meeting that developed out of the class meeting at the time of Adventism's beginnings. Since Methodism was in transition at this time, we find remnants of both the class meeting, and the prayer meeting in early Adventism. However, this prayer meeting is not to be confused with modern-day prayer meetings.

${ }^{1}$ Ellen G. White, Pastoral Ministry (Washington, DC: Review and Herald Pub. Assn., 1948), 150.

${ }^{2}$ Ellen G. White, Gospel Workers (Washington, DC: Review and Herald Pub. Assn., 1948), 197-198. 
It was called the social meeting in Adventism. While Methodism was moving away from class meetings in homes and prayer meetings after a preaching service, Adventists continued both practices. They had social meetings after preaching, as well as social meetings in small home gatherings. ${ }^{1}$

The Methodist model of evangelism had a significant impact on the church's evangelistic program. The SDA district pastors were equivalent to the circuit riders of the Methodist church. The members were organized into class or social meetings, which was the primary strategy for evangelism.

James White, who served with his wife Ellen as one of the early pioneers of the church, describes one of the social meetings that was held during the early days:

Social meetings were marked with great solemnity. Sins were confessed with tears, and there was a great breaking down before God, and strong pleadings for pardon, and a fitness to meet the Lord at His coming. And the humble disciples of the Lord did not seek His name in vain. Before that meeting closed, hundreds testified with tears of joy and they had sought the Lord and found Him, and had tested the sweets of sins forgiven. ${ }^{2}$

A review of the early Adventist articles and letters reveals that the social meetings were a key part of the church life, and attendance was even considered a duty to some. The purpose of the social meeting was to build community and the member through prayer

${ }^{1}$ Russell Burrill, The Revolutionized Church for the $21^{\text {st }}$ Century (Fallbrook, CA: Hart Research Center, 1997), 123.

2James White, Life Sketches, vol. 1 (Battle Creek, MI: Steam Press of SDA Pub. Assn., 1868), 167. 
and testimonies. ${ }^{1}$ Ellen White said it was essential for the church to have social meetings and that young ministers should be taught how to conduct these meetings.

In 1882, she also cautioned that long, prosy talks and prayers are out of place anywhere, and especially in the social meetings. "They weary the angels as well as the people who listen to them. Our prayers should be short, and right to the point. Let the Spirit of God pervade the hearts of the worshipers, and it will sweep away formality and dullness.",2

The Adventist church has largely abandoned this format today. There are some Adventist churches that have built formal small-group structures, but they are not widespread. Within a church there are informal small groups that meet some of the relational needs of people even if this is not their main purpose. Prayer meetings, Sabbath School classes, choirs; Pathfinders, Adventurers, Women's and Men's Ministries, and even committees and boards meet some of these needs if any. ${ }^{3}$

In the summer of 1854 the SDA church launched its first evangelistic tent meeting. Crowds of people attended these meetings out of curiosity about this model of evangelism. ${ }^{4}$ 1883,348 .

${ }^{1}$ Ellen White, "Labor at Camp Meetings," Signs of the Times, Supplement, May 17,

${ }^{2}$ Ellen White, "Christian Work," Review and Herald, October 10, 1882, 625.

${ }^{3}$ Monte Sahlin, Sharing Our Faith (Hagerstown, MD: Review and Herald Publishing Association, 1989), 147.

${ }^{4} \mathrm{~J}$. N. Loughborough, The Church: Its Organization, Order and Discipline (Washington, DC: Review and Herald Pub. Assn., 1907), 103. 
Adventism was now creating a widespread impact and pastors were now organized to plant churches while the members were primary care-givers.

In 1862, after much debate that the church would be "Babylon," the SDA Church was organized with pastors/evangelists to plant churches and elders and deacons to equip the churches. The basic structure of this model was to recapture the evangelistic strategy of the church in the New Testament era. According to Burrill it was intimated by Ellen White that pastors were paid to raise up new churches and if they failed to increase the new churches they simply were not to be paid. ${ }^{1}$

In 1859, James White echoed that we have no settled pastor, but our ministers are all missionaries as were the early ministers of Jesus Christ. Consequently, most of the time they are deprived of the blessings of home. He further expressed that the best proof that God has called a pastor was if he was entering new fields, and raising up churches. ${ }^{2}$ An Adventist evangelist was interviewed by a local newspaper and he explained that the church had no settled pastor. "Our churches are taught to take care of themselves, while nearly all of our ministers work as evangelists in new fields," the pastor is alleged to have said. ${ }^{3}$

In March 1912, the General Conference president, A. G. Daniells, delivered an address to a ministerial institute in Los Angeles, California, in which he emphasized the

${ }^{1}$ Burrill, Revolution in the Church, 168.

${ }^{2}$ James White, "Report of Conference Address," Review and Herald, June 9, 1859, 21.

${ }^{3}$ James White, "Report of Conference Address," Review and Herald, April 15, 1862, 156. 
importance between the pastors and laity in the work of evangelism. In his address, the president warned the workers that he hoped the day would never come when the church would advocate for settled pastors. Here is part of A.G. Daniells's prophetic sermon:

We have not settled our ministers or churches as pastors to any large extent. In some of the very large churches we have elected pastors, but as a rule we have held ourselves ready for field service, evangelistic work and our brethren and sisters have held themselves ready to maintain their church services and carry forward their church work without settled pastors. And I hope this will never cease to be our forward movement work and begin to settle over our churches, to stay by them, and to do their thinking and their praying and their work that is to be done, then our churches will begin to weaken, and to lose their life and spirit, and become paralyzed and fossilized and our work will be on the retreat. ${ }^{1}$

Ron Gladden has found that the work in North America is on the retreat. In the 1870s the SDA Church planted one new church a year for every 1.7 pastors. In 1997 it took 123 pastors to plant a church. ${ }^{2}$ What an overwhelming contrast!

\section{Summary}

There are adequate biblical and theological evidences to prove that equipping the laity for ministry is supported in the Scriptures and in other relevant literature. Both the Old and the New Testament, along with Ellen White and the early SDA church, clearly demonstrate that God's work should not be operated like a "one-man band." Moses tried it, but he failed. Every person has an integral part to play in God's work.

'Burrill, Revolution in the Church, 41.

${ }^{2}$ Ron Gladden, "Evangelism and Church Growth," Ministry, October 1997, 7. 
Jesus, the greatest Leader, demonstrated that He did not want to work alone. He called a small group of twelve disciples, equipped them and sent them out to do His work. Equipping the laity for ministry can also be traced during the early apostolic church, during the time of Ellen White, and in the early SDA church. It is imperative that pastors return to their biblical role and job description in equipping the laity for ministry. 


\section{CHAPTER 4}

\section{ANALYSIS OF FIELD SURVEYS FOR PASTORS \\ AND MEMBERS IN THE WJC OF SDA}

This chapter presents the basic findings of a survey of pastors and members of the West Jamaica Conference of Seventh-day Adventists (WJC/SDA), to discover the current practices of equipping the laity for ministry. The rationale for conducting the survey was included as a part of the questionnaire. ${ }^{\prime}$ An analysis of the surveys done by the pastors and members and the findings are presented in this study.

\section{Rationale for the Surveys}

Having worked in the WJC as a pastor for fourteen years, and recognizing the tremendous challenge that pastors face in equipping the laity for ministry, it became increasingly urgent to conduct a study that would secure, information from members and pastors. Furthermore, an analysis of the survey is critical to ascertain the current practices of equipping and the current factors which create a positive or negative impact in equipping the laity for ministry.

${ }^{1}$ See Appendix E for pastors and Appendix F for church members. 
The sixteenth fundamental of the SDA Church states that the doctrine of spiritual gifts places the responsibility for the training of the congregation on the shoulders of the pastors:

Ministers should not do the work that belongs to the church, thus wearing themselves, and preventing others from performing their duty. They should teach the members how to labor in church and in the community. The minister who does not have the gift of training does not belong to the pastoral ministry, but to another part of God's work. The success of God's plan for the church depends on the willingness and ability of its pastors to train the members to use their God given gifts. ${ }^{1}$

The SDA Church Manual supports Ellen White's view that the greatest help that can be given to our people is to teach them to work for God and to depend on Him, not on the minister. ${ }^{2}$ The members should therefore be taught that ministry should be performed by the entire church community working together, rather than by the pastor alone. If this is the case, then there is a need to discover the role the pastor should play in the training of the laity.

\section{The Survey Given to the SDA Pastors in WJC}

The survey sought to discover the current practices that pastors utilize to equip the laity for ministry in the WJC of SDA. The questionnaires for pastors sought information in five major areas:

1. Self-leadership: How the pastor is equipping himself/herself for ministry

${ }^{1}$ Seventh-day Adventists Believe, 211.

${ }^{2}$ The Seventh-day Adventist Minister's Handbook (Silver Spring, MD: The Ministerial Association General Conference of Seventh-day Adventists, 1997), 128. 
2. The pastor's concept of leadership in the process of equipping the laity for ministry

3. The role the conference plays in supporting the pastor in the process of equipping

4. The pastor's current practices in equipping the laity: What is the pastor's current approach in training the members for various church ministries?

5. The pastor's feedback: Suggestions pastors have regarding the training of the members.

\section{The Survey of SDA Members}

Members of the churches in the WJC were also given questionnaires in order to discover their personal evaluation of equipping and the pastor's role in that process. These questionnaires addressed five major areas:

1. The members' personal demographics

2. The members' evaluation of the pastor's leadership role

3. The members' personal evaluations of the degree to which they felt they were being equipped for the ministry of the church

4. The members' understanding of their personal ministry

5. Some suggestions pastors might use to train the members for ministry. 


\section{Methodology}

The research was descriptive. The survey questions were objective, except for the final question, which sought to obtain valuable suggestions which could be used to equip both pastors and members in WJC. From May 29-June 5, 2002, I traveled throughout West Jamaica to distribute the surveys among pastors and members in that conference. Each pastor was personally given a survey to be completed and collected before I returned to Andrews University on June 5, 2002.

The surveys for members were distributed to ten members in each of the main churches of each pastoral district. Each respondent was given an envelope to be sealed when the survey was completed. These surveys were then given to Annette Thompson, administrative assistant to the Executive Secretary of the WJC.

On June 5, 2002, I arrived at the conference office to collect the completed surveys. Only seven pastors, 19 percent, responded. The response from the laity was rather gratifying. Of the 360 members who were given the survey, 199 members, 55 percent, responded. I made further plans with Ms. Thompson to collect the remaining surveys and send them to me at Andrews University by June 30, 2002. Six additional pastors responded, 21 percent, and five members, 29 percent.

At the end of June, I wrote a letter to all the pastors who did not complete the surveys. On July $24^{\text {th }}$ my wife traveled to West Jamaica. I asked her to collect the rest of the surveys. She received five more from pastors, 23 percent, and eleven from members, 8 percent. On July 31,2002 , I began the process of analyzing the surveys. A total of 
eighteen completed surveys were received from the pastors, 50 percent of the total distributed, and 216 completed surveys from the members, 60 percent of the total distributed.

The questionnaires for pastors in the WJC sought to address five major areas: selfleadership, concepts of leadership; the relationship of the pastors to the conference, and the role of the conference in supporting the pastors in the process of equipping the laity for ministry, the equipping ministry of the pastors, and practical suggestions from the pastors in regard to the training of members.

\section{Self-Leadership}

This area of equipping focuses on the pastors and their ability to assume responsibility for their own training. John Grys, a recognized author on equipping pastors for equipping the laity, serves as a pastor of a church with over four hundred members. $\mathrm{He}$ discovered the importance of equipping himself and says,

The greatest growth barrier to my congregation is my own growth. This is why Jesus spent so much time doing what is called today self-leadership. He spent time with the Father, seeking to constantly align His heart to the heart of the Father. Like ours, His society was one of turmoil, change and uncertainty. To thrive in that kind of environment required a heart continually aligned with the Father's heart. Empowering leadership requires the heart to be continually and fully aligned with Christ, the head of the church. ${ }^{1}$ $11-12$.

'John Grys and Greg Schaller, "Growing a Healthy Church," Ministry, March 2001, 
Grys goes on to say, "This alignment is demonstrated in my desire to serve the mission of the congregation." Dee Hock, another authority in the field who definitely experienced the personal benefits of personal anchoring, concludes that a leader must spend at least 50 percent of his or her time in the area of self-leadership. ${ }^{2}$

\section{The Adventist Pastors}

Questionnaires were sent out to twenty-eight pastors in the WJC and only eighteen questionnaires were returned. See table 1.

Of the thirty-six pastors who received the survey, eighteen responded. The 50 percent who responded consisted of ten pastors with college degrees, seven with Master's degrees and one with a Master of Divinity. At the first quadrennial session convened in the West Jamaica Conference, the secretariat commented that several pastors were sponsored to do the Master of Arts in Religion during the summers at Northern Caribbean University. ${ }^{3}$ This gives evidence that the West Jamaica Conference is making efforts to upgrade the pastors' education.

However, there are concerns, such as sponsoring pastors to attend other SDA institutions of higher learning. An investment in education often yields positive results. As for the length of time in ministry, two pastors, 11 percent, have been in ministry for one to

${ }^{1}$ Tbid.

${ }^{2}$ Dee Hock, "The Art of Choradic Leadership," Leader to Leader, Winter 2002, 15.

${ }^{3}$ West Jamaica Conference, 6 . 
TABLE 3

PASTOR'S PROFILE AND PERSONAL EVALUATION

Pastor's Profile and Personal Evaluation

Number of Persons Who

Responded

Highest education level attained:

High school

College

10

M.A.

M.Div.

Doctorate

Years in the ministry:

$1-5$ years 2

6-10 years

6

11-20 years

8

21-30 years

1

31 or more

Average time spend in personal prayer each day

15 minutes

30 minutes

60 minutes

90 minutes or more

Average time spent in personal Bible study each day

less than 1 hour

one hour

two hours

more than 3 hours

Time spend preparing each sermon

less than 1 hour

one hour

two hours

more than 3 hours 
Table 3-Continued.

Number of sources used in sermon preparation

$\begin{array}{ll}\text { one } & 0 \\ \text { three-four } & 9 \\ \text { five-eight } & 7 \\ \text { nine or more } & 2\end{array}$

Time spent in family worship each day

$\begin{array}{ll}5-10 \text { minutes } & 1 \\ 11-20 \text { minutes } & 8 \\ 21-30 \text { minutes } & 5 \\ 31 \text { minutes or more } & 4\end{array}$

Time spent in leisure activities each week

less than 1 hour 4

one hour 4

two hours $\quad 6$

more than 3 hours 4

five years. Six pastors, 33 percent, have been in ministry for six to ten years. Eight

pastors, 44 percent, have been in ministry for eleven to twenty years. And one, 6 percent, has been in ministry for over thirty-one years.

Prayer and personal Bible study are critical in enhancing the pastor's self-

leadership. Jesus set the example. Very early in the morning while it was still dark Jesus got up, left the house, and went to a solitary place where He prayed (Mark 1:35). Jesus also spent all nights in prayer before He chose His disciples (Luke 3:21). It is said that Martin Luther prayed four hours each day despite his busy life. 
The data revealed that six pastors, 33 percent, spend an average time of fifteen minutes in prayer. Eight pastors, 44 percent, spend an average of one hour each day in prayer. Figures in personal Bible studies show that six pastors, 33 percent, spend an average of less than one hour each day in prayer; and eight pastors, 44 percent, invest in one hour of Bible study each day. Ellen White confirms that Jesus would replenish His soul by praying and searching the Scriptures before He set forth to minister to the souls of men. ${ }^{1}$

Ten pastors, 56 percent, spend more than three hours preparing their sermons, and five, 28 percent, utilize one hour in sermon preparation. The number of sources pastors used in their sermons revealed that nine pastors, 50 percent, used three to four sources, while seven pastors, 39 percent, used five to seven sources. Two pastors, 11 percent, used nine or more sources.

Family worship has been said to be a spiritual anchor in every SDA home. In a ten-year study with 730 SDA youths, Roger Dudley found that 56 percent of those young people who were spiritually weak rarely or never had family worship. ${ }^{2}$ The data in table 3 show that one pastor, 6 percent, spends 5-10 minutes in family worship daily. Eight pastors, 44 percent, spend 11-20 minutes in family worship. Five pastors, 28 percent, spend 21-30 minutes, and four pastors, 22 percent, spend more than 30 minutes in family worship.

'White, Pastoral Ministry, 282.

${ }^{2}$ Roger L. Dudley, Why Our Teenagers Leave the Church (Hagerstown, MD: Review and Herald Publishing Association, 2000), 42. 
Recreation is vital to those who are engaged in physical labor, and is still more essential for those whose labor is principally mental. Four pastors spend less than one hour each week in leisure activities, four more just one hour each week. Six pastors, 33 percent, utilized two hours in recreation, and four, 22 percent, spend more than three hours per week in leisure activities.

On a Likert scale, with 1 indicating a strong disagreement, and 5 a strong agreement, the pastors indicated their understanding of the pastor's leadership role in equipping the laity for ministry. Table 4 presents these figures.

The pastors were asked to evaluate their leadership roles. Many of the pastors in the WJC demonstrated positive qualities of good leadership. Fourteen of the eighteen pastors, 78 percent, agree that pastors should help the members to identify their gifts. Two pastors, 11 percent, are neutral, while the other two seem to disagree with the other fourteen. Fifteen pastors, 83 percent, strongly agree that it is not good for the pastors to do most of the church work. Seven pastors, 39 percent, indicated that they are not involved in every activity of the church, and 10 pastors, 56 percent, strongly agree that they are involved. Twelve pastors, 67 percent, support the view that the members usually depend on them to make the decisions, while four pastors disagreed, indicating that the members do not depend on them to make the decisions. 
TABLE 4

\section{THE PASTOR'S UNDERSTANDING OF HIS/HER ROLE IN LEADERSHIP}

The pastor's self-evaluation of his/her role in the local church Strongly disagree Strongly

agree

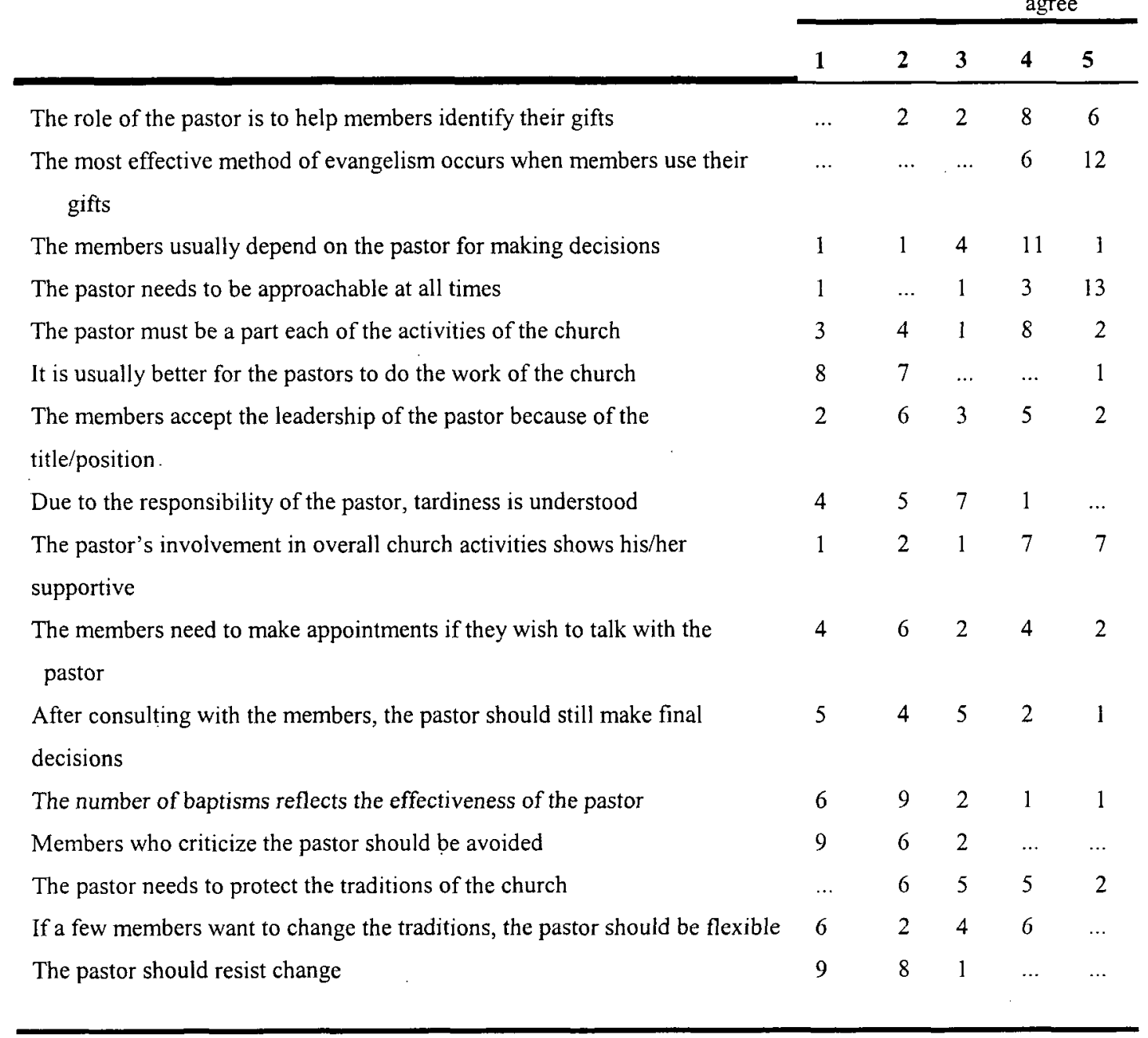


We live in a time unlike any other time, different from what any living person has known. It is not merely that things are changing. Change itself has changed. ${ }^{1}$ One of the critical marks of leadership is the leaders' ability to adapt to change. ${ }^{2}$ The majority of pastors, 94 percent, in the WJC indicate that the pastor should be flexible to change. Eight pastors, 44 percent, disagree that the members' acceptance of the pastor's leadership is due to their title or position, while seven pastors, 39 percent, strongly agree. Three pastors, 17 percent, indicated a neutral response.

There were nine pastors, 50 percent, who indicated their members do not seem to accept tardiness; however, seven pastors, 39 percent, indicated a neutral position on the part of the members accepting pressing responsibilities as an acceptable excuse for tardiness.

The SDA Minister's Handbook states that pastors may be many things, but one thing they must be is spiritual leaders. ${ }^{3}$ George Barna points out that most American churches have pastors who are not leaders. The result of this survey among Protestant pastors reveals that most pastors do not even consider themselves to be leaders. Fewer than one out of every twenty pastors believes he/she has the spiritual gift of leadership. ${ }^{4}$

${ }^{1}$ Easum, 19.

${ }^{2}$ Michael W. Foss, Power Surge: Six Marks of Discipleship (Minneapolis, MN: Ausburg Fortress Press, 2000), 53.

${ }^{3}$ Seventh-day Adventist Minister's Handbook, 113.

${ }^{4}$ Bama, The Habits of Highly Effective Churches, 38-39. 
Research indicates that growing churches usually have strong pastoral leadership. Strong does not mean dominating or manipulative leadership, and leadership must not be confused with lordship. ${ }^{1}$

Peter makes that distinction when he prescribed that shepherds should not lord it over those entrusted to them (1 Pet 5:2-3). Jesus' model of leadership shows that, whereas worldly rulers are over those who lead, Christian leaders are among those they lead (Matt 20:25-28).

Pastors were asked to evaluate the conference's role in designing a holistic plan for equipping the pastors and the local church members. (See table 5.) They gave the following responses: Fourteen pastors, 78 percent, believe that the conference sets the number of baptisms as top priority. Sixteen pastors, 89 percent, affirm that the conference sponsors training programs that are conducted at the local churches.

Notwithstanding the above affirmation, seven pastors, 39 percent, have stated that they have no idea whether or not the conference has a plan for nurturing members. Three of them, 17 percent, stated that they were not aware of any conference plans to nurture members. Only eight pastors, 44 percent, affirmed that the conference has plans in place for nurturing. While the majority of pastors, 94 percent, affirm that the policies of the conference allow them to utilize a variety of approaches to involve the laity, five pastors, 28 percent, disagreed. Nine pastors, 50 percent, indicated that the conference supported their 
TABLE 5

\section{THE PASTOR AND HIS/HER RELATIONSHIP TO THE CONFERENCE}

\begin{tabular}{|c|c|c|c|c|c|}
\hline \multirow[t]{2}{*}{ The pastor's understanding of the conference and its function } & \multicolumn{3}{|c|}{ Strongly disagree } & \multicolumn{2}{|c|}{$\begin{array}{l}\text { Strongly } \\
\text { agree }\end{array}$} \\
\hline & 1 & 2 & 3 & 4 & 5 \\
\hline The conference sets the number of baptisms as the top priority & 1 & 3 & $\ldots$ & 8 & 6 \\
\hline The conference sponsors training programs for pastors & $\cdots$ & 2 & $\cdots$ & 12 & 4 \\
\hline The conference encourages pastors to train new members for ministry & $\ldots$ & $\ldots$ & 2 & 9 & 7 \\
\hline The conference encourages a holistic program for evangelism & $\cdots$ & $\ldots$ & 1 & 12 & 5 \\
\hline The conference makes an evangelism budget available to pastors & 1 & 1 & $\cdots$ & 3 & 13 \\
\hline The conference goals for baptism are established by the local church & 3 & 8 & 1 & 4 & 2 \\
\hline The conference vision for evangelism is known by the pastors & $\ldots$ & 1 & $\cdots$ & 10 & 7 \\
\hline The conference has a plan for nurturing new members & $\cdots$ & 3 & 7 & 6 & 2 \\
\hline The conference administrators are available if you need to consult with them & $\cdots$ & 1 & 1 & 11 & 5 \\
\hline The conference policies support the pastor's role as a facilitator for change & 2 & 2 & 5 & 8 & 1 \\
\hline $\begin{array}{l}\text { The conference policies allow for a variety of approaches to involving the } \\
\text { laity }\end{array}$ & $\cdots$ & $\ldots$ & 1 & 15 & 2 \\
\hline
\end{tabular}

role as a facilitator of change; five, 28 percent, were neutral, and four, 22 percent, felt that the conference did not support their role as change agents.

In research carried out among three conferences in Jamaica, Denton Rhone discovered that the conferences were allowed in a limited way to participate in goal setting 
and plans. ${ }^{1}$ However, West Indies Union indicates the numerical goals for baptism. As a result, pastors prioritize the union goals and spend less time in the training of members and other areas. The problem is that those conferences which do not meet the union goals are labeled as unproductive and not supportive of the church. This is reflected in the summary from Rhone:

At the year-end Division meetings, evangelistic goals are given to the Unions and then divided among the Conferences, who divide them among the pastors, who divide them among the churches. No one ever stops to ask why such an emphasis on numbers and even more importantly, why the local church cannot set its own goals for baptism. A president or administrator who wishes to serve at another level of the church perhaps would not be considered if he chooses to take an approach to his evangelism that would not accommodate the higher system of recognition. Change in this cycle of recognition and promotion of evangelism cannot come from below, it has to come from above. $^{2}$

Rick Warren is quick to point out that catching fish on their terms means letting your. target determine your approach. When a person goes fishing, he or she does not use the same kind of bait for every kind of fish. A person must use the bait that matches the fish he/she wants to catch. $^{3}$ George Barna summarizes the point by affirming that ministry is not about programs, it is all about people. ${ }^{4}$

${ }^{1}$ Denton Rhone, Churching the Rich: How to Introduce Professionals, Business People and Celebrities to Christ (Mandeville, Jamaica: Dikah Publishers, 2001), 48.

${ }^{2}$ Ibid., 48, 49.

${ }^{3}$ Warren, 196.

${ }^{4}$ George Barna, User Friendly Churches (Ventura, CA: Regal Books, 1991), 42-43. 


\section{The Pastor and His/Her Understanding of Ministry}

When the pastors were asked to evaluate their equipping process, six pastors, 33 percent, affirmed that they are not satisfied with the way the members are being equipped for ministry. Likewise, seven pastors, 39 percent, are not even sure if there is anything being done to help equip the laity for ministry. Only five pastors, 28 percent, stated that they are satisfied with help that is given the members towards equipping them (see table 6).

At the First Quadriennial Session of the WJC held in Montego Bay, Jamaica, in the year 2002, the Personal Ministries Director, Pastor Egnal Grant, explained to the delegates that during the past four years 149 crusades were conducted. A total of 3,710 persons were baptized. Among the laity there were six centurions and five double centurions. ${ }^{1}$ Pastor Glen coordinates evangelism among the pastors in the WJC. He reported that for the first time in the history of WJC, more than one thousand persons were baptized every quarter. In 1999, when I left the conference to study at Andrews University, there were twenty-three centurions, five double centurions, two triple centurions, and one pastor who baptized over four hundred persons. ${ }^{2}$

The results recorded in table 6 show that pastors are actively involved in winning souls. In 2001, eight pastors, 44 percent, baptized fewer than 200 persons, and ten pastors, 56 percent, baptized more than 200 souls. The most commonly used evangelistic

${ }^{1}$ West Jamaica Conference, 16.

${ }^{2}$ West Jamaica Conference, July 2002, 120-125. 
TABLE 6

PASTOR'S UNDERSTANDING OF MINISTRY

Question

Number of Persons Who Responded

No. of members you currently pastor:

$\begin{array}{ll}200 \text { or less } & 0 \\ 201-500 & 3 \\ 501-1,000 & 7 \\ 1,001 \text { or more } & 8\end{array}$

No. of baptisms you have performed in 2001:

200 or less

201-500

10

$501-1,000$

0

1,001 or more

0

No. of workshops conducted to train the laity to give Bible studies:

$\begin{array}{ll}\text { none } & 5 \\ \text { one } & 3 \\ \text { two } & 3 \\ \text { three } & 4 \\ \text { four } & 2 \\ \text { five or more } & 1\end{array}$

No. of evangelistic series conducted by the pastor in 2001:

$\begin{array}{ll}\text { none } & 2 \\ \text { one } & 7 \\ \text { two } & 4 \\ \text { three } & 3 \\ \text { four } & 1 \\ \text { five or more } & 1\end{array}$


Table 6-Continued.

No. of evangelistic efforts conducted by the laity in 2001:

none

one

two

three

four

five or more

Methods of evangelism most commonly used in your churches:

tent crusade

church crusade

home Bible study

personal

Approx. how many members do you visit each week

$1-3$

4-6

3

$7-9$

6

10-12

2

13 or more

6

To what extent are you satisfied with how members are involved in home visits?

$\begin{array}{llll}7 & 4 & 2 & 2\end{array}$

To what extent are you satisfied with how members are involved in evangelism? 6

$\begin{array}{llll}6 & 3 & 3 & 0\end{array}$


methods are tent and church crusades; thirteen pastors, 72 percent, used this method of evangelism.

An increasing challenge that pastors face in the WJC is the level of equipping that pastors perform among the members. When pastors were asked to evaluate their satisfaction in equipping the members, six pastors, 33 percent, were not satisfied with the way in which the members are being equipped for ministry. What raises a greater level of concern are the seven pastors, 39 percent, who are not even sure if anything is being done to help pastors equip the laity for ministry.

Regarding home visits, ten pastors, 56 percent, are dissatisfied with their members' involvement in home visitations. Added to this concern are the four, 22 percent, who are not sure if their members are engaged in home visitations. Only four pastors stated that they were satisfied with the way their members were involved in home visitations. The overall statistics in table 6 reveal that the majority of pastors surveyed in the WJC are not satisfied with the level of equipping they give to the members. Therefore, there is an urgent need to develop a strategy to equip the laity for ministry.

\section{Pastors' Suggestions for Equipping the Laity}

Pastors were asked to give suggestions that might be helpful to equip the laity for ministry. Table 7 indicates their responses and the frequency of the responses.

The area of training was given priority attention among the pastors. It was mentioned twenty-six times, indicating the integral part it plays in the process of equipping 
TABLE 7

\section{SUGGESTIONS FROM PASTORS IN EQUIPPING THE LAITY}

\begin{tabular}{lc}
\hline Categories/areas of emphasis & $\begin{array}{c}\text { Frequency (no. of } \\
\text { responses) }\end{array}$ \\
\hline Training & 23 \\
Teaching & 10 \\
Spiritual discipline & 8 \\
Leadership & 7 \\
Workshops & 6 \\
Technology & 3 \\
Incentives & 3 \\
Undecided & 3 \\
Festival of laity & 2 \\
Books (supply of materials) & 2 \\
\hline
\end{tabular}

the laity for ministry. Paul Watson points out that training is not the strategy of most churches. Many members believe that pastors should devote much of their time to the weak members of the church. However, while Christ ministered to the weak, $\mathrm{He}$ concentrated His training efforts on a few capable, committed, and willing persons. $\mathrm{He}$ knew that He would reach the masses by training the few. ${ }^{1}$

'Paul E. Watson, "Equipping Church Members in Community, A Follow-up Strategy for Spiritual Body-Building Groups in the Brandon Seventh-day Adventist Church" (D.Min. dissertation, Andrews University, 2001), 90. 
Most of the concerns regarding training were raised in the area of Bible studies, which was mentioned seven times, training in leadership six times, training of sermon preparation, four times, training of lay-preachers, four times, training in technology, three times, and the training of elders, three times.

The second highest rating among the pastors was teaching, mentioned ten times. Three pastors believed that members should be taught Bible prophecies, three believed they should be taught the history of the church, two believed they should be taught the art of caring for each other, and two believed they should be taught in the area of spiritual gifts. Spiritual discipline was third among the ranking, with prayer and fasting being indicated as vital areas among the members, mentioned eight times.

Leadership is also important in equipping the laity for ministry and was mentioned seven times. Roy Pointer points out that growing churches always have effective leadership. ${ }^{1}$ The opinion that workshops should be conducted in the area of spiritual gifts received a score of six. Another area of concern was incentives to be given to the laity. It was indicated that the conference should conduct the Festival of the Laity twice per year as a source of motivation. Books and other reading materials were also mentioned as being needed to provide useful information in the area of evangelism.

'Roy Pointer, How Do Churches Grow: A Guide to the Growth of Your Church, (London: MARC Europe, 1984), 79. 


\section{The Survey for the SDA Members}

The survey for the SDA members in the WJC sought information in five major areas:

1. Demographics and profile of personal spirituality

2. The members' understanding of the pastoral leadership role in the local church.

3. An evaluation of the church ministries of the local church from the members' perspective and how satisfied or dissatisfied the members are with the training members receive from their pastors

4. A self-evaluation of personal ministry

5. The members' feedback regarding their views on what methods the pastors might use to train the church members.

There are 216 members who responded to the questionnaire that was sent out to thirty-two churches in the WJC of SDA churches.

Table 8 indicates that of the 216 members who responded to the questionnaires, 148 members, 69 percent, have been in the church from eleven to more than thirty-one years. Only sixty-five have been baptized Adventists for one to ten years. When asked to evaluate their personal prayer life, 108 members, 50 percent, stated that they spent only fifteen minutes or less per day in prayer, while 116 members, 54 percent, spent less than an hour in personal Bible study. Sixty-three members invested 11-20 minutes each in family worship, and eighty members had read the Bible through once; nine members had read the 
Bible through four or more times. One hundred and sixteen respondents, 54 percent, pray for more than twelve people each week.

Members were requested to evaluate their understanding of the role of pastors, particularly as it relates to leadership in the local church, and the following were their responses: Ninety-eight members agreed that the role of the pastors is to identify the members' gifts, while fifty members simply did not know. Interestingly, 160 respondents, 86 percent, support the pastors' overall involvement in the churches. One hundred and twenty-one members, 56 percent, disagreed with the statement that pastors make the final decisions, even after consulting with the members. One hundred and six members, 48 percent, support the view that they were the ones to make the final decisions. See table 9. When asked to accept the pastors' leadership because of his title or position, eighty members, 34 percent, disagreed, while eighty members, 34 percent, agreed. Thirty-eight members, 18 percent, could not make up their minds. Tardiness was not considered excusable by 105 members, 49 percent, but seventy-four members would accept the pastors' tardiness due to his/her busy schedule. It is encouraging that the majority of the members, 108, 83 percent, perceive their pastors to be approachable at all times.

Sixty-six members did not agree that they were being trained to give Bible studies, while eighty-two felt that they were being trained, and sixty-two indicated a neutral response. The response towards training to welcome visitors received high marks of 139 . Members were asked to evaluate their understanding of the ministries that occur within the churches. 
TABLE 8

MEMBERS' PROFILE

Member's profile and personal evaluation Number of persons who responded

Number of years you have been an Adventist

$\begin{array}{ll}1-5 & 28 \\ 6-10 & 37 \\ 11-20 & 40 \\ 21-30 & 51 \\ 31 \text { or more } & 57\end{array}$

Average time in personal prayer each day

15 minutes

108

30 minutes

60 minutes

36

90 or more minutes

12

Average time in personal Bible study each day

less than 1 hour

116

1 hour

64

2 hours

2

3 hours or more

Time spent in family worship each day

$5-10$ minutes

11-20 minutes

21-30 minutes

44

31 minutes or more

50

How many times have you read the Bible through?

once

twice

29

three times

19

four or more times 
Table 8-Continued.

How many persons do you pray for each week?

$\begin{array}{lr}1-2 & 7 \\ 3-5 & 23 \\ 6-8 & 38 \\ 9-11 & 16 \\ 12 \text { or more } & 125\end{array}$

Table 9 shows how they responded. One hundred and fourteen, 53 percent, support the priority that is given to the baptism of new members, fifty-seven members, 26 percent, are not satisfied; and forty-nine, 23 percent, indicated a neutral position. While sixty-four members, 30 percent, are dissatisfied with the equipping of members for ministry, seventy-five respondents, 35 percent, affirm the equipping process, and seventy-four, 34 percent; remain neutral. 
TABLE 9

MEMBERS' UNDERSTANDING OF PASTORAL LEADERSHIP

\begin{tabular}{|c|c|c|c|c|c|}
\hline \multirow[t]{2}{*}{ Question (or Statement) } & \multicolumn{3}{|c|}{ Strongly disagree } & \multicolumn{2}{|c|}{$\begin{array}{l}\text { Strongly } \\
\text { agree } \\
\end{array}$} \\
\hline & 1 & 2 & 3 & 4 & 5 \\
\hline The pastor helps the members identify their spiritual gifts & 16 & 34 & 58 & 78 & 20 \\
\hline The members usually depend on the pastor for making decisions & 46 & 75 & 27 & 43 & 13 \\
\hline Your pastor is someone easy to talk with at any time & 1 & 5 & 18 & 62 & 118 \\
\hline The pastor must be a part of each of the activities of the church & 20 & 29 & 25 & 69 & 59 \\
\hline It is usually better for the pastor to do the work of the church & 59 & 82 & 31 & 16 & 18 \\
\hline $\begin{array}{l}\text { The members accept the leadership of the pastor because of the } \\
\text { title/position }\end{array}$ & 32 & 51 & 38 & 58 & 22 \\
\hline Due to many the responsibilities of a pastor, tardiness is understood & 51 & 54 & 25 & 47 & 27 \\
\hline $\begin{array}{l}\text { The pastor's involvement in overall church activities shows s/he is } \\
\text { supportive }\end{array}$ & 5 & 16 & 20 & 79 & 86 \\
\hline $\begin{array}{l}\text { The members need to make appointments if they wish to talk with the } \\
\text { pastor }\end{array}$ & 40 & 53 & 29 & 58 & 26 \\
\hline $\begin{array}{l}\text { After consulting with the members, the pastor should still make final } \\
\text { decisions }\end{array}$ & 41 & 65 & 34 & 41 & 28 \\
\hline
\end{tabular}


In the area of involving new members in evangelism, ninety-three respondents, 43 percent, are dissatisfied, 31 percent are satisfied, and 28 percent responded neutral. In vital areas such as nurturing new members, sixty-three members were dissatisfied, only 29 percent. Sixty-six, 31 percent, were satisfied. The positive response of 110 respondents, 51 percent, towards members caring for each other is gratifying even though 23 percent remain neutral.

Members were asked to evaluate their understanding of the ministries that occur within the churches. Table 10 shows how they responded. One hundred and fourteen, 53 percent, support the priority that is given to the baptism of new members; fifty-seven members, 26 percent, are not satisfied; and forty-nine, 23 percent, were neutral. While sixty-four members, 30 percent, are dissatisfied with the equipping of members, seventyfive respondents, 35 percent, affirm the equipping process; and, seventy-four, 34 percent, gave a neutral response.

In the area of involving new members in evangelism, ninety-three respondents, 43 percent, indicated that they were dissatisfied, 31 percent were satisfied, and 28 percent were marked as neutral. In vital areas such as nurturing new members, eighty-six members, 32 percent, are satisfied, seventy-three members, 34 percent, are dissatisfied, and sixty-three members, 29 percent, remain neutral. Eighty-two respondents, 38 percent, indicated satisfaction with the training to give Bible studies; even though 29 percent were neutral. One hundred and thirty members, 60 percent, were satisfied with the training given 
TABLE 10

\section{MEMBERS AND THEIR UNDERSTANDING OF CHURCH MINISTRY}

\begin{tabular}{|c|c|c|c|c|c|}
\hline \multirow[t]{2}{*}{ Question } & \multicolumn{3}{|c|}{ Very dissatisfied } & \multicolumn{2}{|c|}{$\begin{array}{c}\text { Very } \\
\text { satisfied }\end{array}$} \\
\hline & 1 & 2 & 3 & 4 & 5 \\
\hline $\begin{array}{l}\text { To what extent are you satisfied with the priority placed on new-member } \\
\text { baptisms? }\end{array}$ & 28 & 29 & 49 & 55 & 59 \\
\hline $\begin{array}{l}\text { To what extent are you satisfied with how members are equipped for } \\
\text { ministry? }\end{array}$ & 28 & 36 & 74 & 46 & 29 \\
\hline $\begin{array}{l}\text { To what extent are you satisfied with how members are trained to make home } \\
\text { visits? }\end{array}$ & 25 & 51 & 60 & 37 & 33 \\
\hline $\begin{array}{l}\text { To what extent are you satisfied with how members are involved in } \\
\text { evangelism? }\end{array}$ & 46 & 47 & 50 & 40 & 26 \\
\hline To what extent are you satisfied with the nurturing the members receive? & 31 & 42 & 63 & 46 & 30 \\
\hline $\begin{array}{l}\text { To what extent are you satisfied with how the church uses your spiritual } \\
\text { gifts? }\end{array}$ & 13 & 24 & 41 & 65 & 59 \\
\hline To what extent are you satisfied with members' training to give Bible studies? & 30 & 33 & 62 & 46 & 36 \\
\hline To what extent are you satisfied with members' training to pray for others? & 15 & 23 & 57 & 59 & 53 \\
\hline To what extent are you satisfied with members' training to welcome visitors? & 16 & 22 & 42 & 52 & 78 \\
\hline To what extent are you satisfied with members' training to care for each other? & 21 & 30 & 50 & 66 & 44 \\
\hline
\end{tabular}


for welcoming visitors. The positive response of 110 respondents, 51 percent, towards members caring for each other is gratifying even though 23 percent remain neutral.

Table 11 evaluates the response to some of the basic ministries that are vital to the growth of the church. Praying for each other demonstrates a caring relationship. Eightyeight members, 41 percent, pray for one to three persons each week, while fifty members, 26 percent, pray for ten or more persons weekly. Giving Bible studies raises concerns regarding the importance of sharing God's word with others. Sixty-four persons, 30 percent, do not give any Bible studies.

Overall, the members are involved in outreach activities, such as distribution of literature and evangelistic efforts. When it comes to small groups, 120 respondents, 56 percent, are members of a small group, and fifty-nine members, 27 percent, are not part of a small group. Even though the majority of the respondents are part of a small group and seventh-six members, 35 percent, meet on a weekly basis, seventh-two respondents, 33 percent, have not produced any baptisms from these small groups. It is interesting to point out that forty-two members, 19 percent, have had between one to five baptisms, and seven members, 3 percent, have had more than twenty-one baptisms.

\section{Members' Suggestions for Equipping the Laity}

Members were to make suggestions on how pastors should equip the laity and the following were their responses (see table 12). One of the most effective ways that a pastor 


\section{TABLE 11}

MEMBERS' EVALUATION OF THEIR

PERSONAL MINISTRY

Question

Number of persons who responded

Number of persons you pray with each week

1-3

4-6

7-9

13

10 or more

Number of Bible studies given each week

one

two

three

37

four

19

five

No: of outreach activities members engage in weekly

$\begin{array}{ll}\text { none } & 44 \\ \text { one } & 58 \\ \text { two } & 51 \\ \text { three } & 31 \\ \text { four } & 11 \\ \text { five+ } & 16\end{array}$

No. of pieces of literature distributed each week

$1-10$

127

$11-20$

11

$21-40$

1

41-60

2

61 or more

4 
Table 11-Continued.

No. of evangelistic efforts conducted by your church

$\begin{array}{ll}\text { none } & 14 \\ \text { one } & 34 \\ \text { two } & 41 \\ \text { three } & 30 \\ \text { four } & 14 \\ \text { fivet } & 39\end{array}$

No. of small groups organized by your church

none $\quad 22$

$1-3 \quad 14$

4-6 28

$\begin{array}{ll}7-9 & 17\end{array}$

10 or more $\quad 20$

Are you a member of a small group ministry in your church?

no

yes

How often does your small group meet?

$\begin{array}{lr}\text { not at all } & 20 \\ \text { weekly } & 76 \\ \text { bi-weekly } & 11 \\ \text { monthly } & 28 \\ \text { quarterly } & 4\end{array}$

How many persons have been baptized during the previous 12 months as a result of your small group?

$\begin{array}{lr}\text { none } & 72 \\ 1-5 & 42 \\ 6-10 & 11 \\ 11-20 . & 11 \\ 21 \text { or more } & 7\end{array}$


can utilize in developing a successful ministry is to listen to the feedback of the members. These members were asked to give suggestions that pastors can employ to equip the laity for ministry. On the left, table 12 indicates the categories or areas of emphasis, and the right shows the frequency to which these categories are mentioned.

Table 12 indicates that training was given a high priority among the members. The frequency of training occurs 185 times, training to conduct Bible studies was mentioned sixty times, training to conduct seminars fifty-six times, training to preach occurs forty times, training to do house-to-house visitation fifteen times, training to distribute SDA literature eleven times, training in technology five times, training to visit prisons four times. The primacy that training is given shows how important it is among the members. D. L. Moody reportedly said that he would rather train ten men than to win ten souls. Our task is never done if the saved are not growing in the Lord and getting people saved. ${ }^{1}$ George Gladis supports the importance of training when he states that one of the marks of highly innovative churches today is the giving away of ministry to people. Pastors should function as coaches and give advice in training, equipping, and encouraging those in the front line of ministry: the people. $^{2}$

${ }^{1}$ Larry Lewis, Organize to Evangelize: A Manual for Church Growth (Nashville, TN: Broadman Press, 1988), 106.

${ }^{2}$ George Gladis, Leading the Team-Based Church (New York: Jossey-Bass, 1999), 124. 
Seminars have taken second place among the categories. It occurred fifty times.

Health, finance, and witnessing seminars are among those mentioned. Small groups took third among the list; it occurred forty-eight times. Carl George affirms the significance of small-group ministries. These small groups meet together in individual units of ten and then together at a big worship-celebration convention. Small groups become centers of

\section{TABLE 12}

\section{MEMBERS' SUGGESTIONS ON HOW PASTORS SHOULD EQUIP THE LAITY}

\begin{tabular}{ll}
\hline Categories (areas members want pastors to focus on) & Frequency \\
\hline Training (Bible Study, preaching, tract distribution, house to house visitation, etc.) & 185 \\
Seminars (health, finance, etc.) & 56 \\
Small Groups & 48 \\
Teaching (27 Fund. Beliefs, E. G. White, prophecies, etc.) & 41 \\
Spiritual discipline (fasting and prayer) & 26 \\
Leadership (impartiality, modeling, and exemplary living) & 26 \\
Social interaction (pastor's relations with people, loving them) & 25 \\
Workshops (scheduling, organizing, self-discipline) & 24 \\
Involvement in church activities) & 18 \\
Discipleship training (Train a few to train others) & 13 \\
Open dialogue (feedback from members) & 8 \\
Counseling (family life and youth) & 7 \\
Library (developing personal library) & 4 \\
Pastor's Bible class (pastor's regular special class) & 3 \\
Youth and education (high school, college, etc.) & 2 \\
Pastors and team work (working with other pastors) & 2 \\
Pastor's sincerity (pastors to be original and not copy USA styles) & 2 \\
Social ministry (catering for members financial need) & 2 \\
No response & 61 \\
\hline
\end{tabular}


evangelism, discipleship, and pastoral care because they have learned to provide quality care in small, humble structures of ten people who meet together. ${ }^{1}$

Teaching was mentioned forty-one times, emphasizing that pastors need to incorporate more teaching into their ministry. Members are asking for more teaching from the writings of Ellen White, eighteen times, the history of the SDA church, fourteen times, and the teaching of Bible prophecies, e.g., Daniel and Revelation, eight times. Jesus was the Master Teacher; He employed a tremendous amount of teaching methodologies in His ministry. He taught the people object lessons that were relevant to their everyday lives. Ellen White emphasizes that Jesus' method of teaching was more relational than methodical. He spent time with people during their trials and hardships. He taught them as they sat together on the mountainside, sometimes beside the sea, or from the fisherman's boat, and sometimes as they walked along the way. ${ }^{2}$

In the area of Spiritual Disciplines, fasting and prayer was mentioned twenty-six times. One member states the truism, "Where there is more prayer, there is more power." According to Purves and Partee, prayer should be regarded as an awesome mystery, because it is a miracle that God listens and responds to us. These authors confirm Calvin's

${ }^{1}$ Carl F. George, The Coming Church Revolution: Empowering Leaders for the Future (Grand Rapids, MI: Fleming H. Revell, 2000), 195.

${ }^{2}$ Ellen G. White, Education (Boise, ID: Pacific Press Publishing Association, 1902), 8485. 
statement, "The true test of faith lies in prayer." Jesus' life and ministry were covered in prayer, and the members of the churches who responded to the survey recognized the importance of prayer in their lives.

Leadership comes next, being mentioned twenty-six times. This kind of leadership is the ability to inspire and motivate others. Aubrey Malphurs describes this type of leadership as having everything to do with one's organizational direction and determines where one's ministry is heading. ${ }^{2}$ The members are asking the pastors to be exemplary in their leadership, to be role models, and to use their leadership as a means of motivation. Maxwell also perceives this type of leader as a model, a mentor, and a person who has the ability to instill in the potential leader the desire and ability to do the work. ${ }^{3}$

Social interaction was also mentioned twenty-six times. Members would like to know that the pastor is a person who is approachable, loving, and able to relate to people from any stratum of life. Workshops was cited twenty-four times, while involvement in church activities was mentioned eighteen times. James Cress is quick to point out that many people are not just looking and longing for friendly greetings in a church, they need and

'Andrew Purves and Charles Partee, Encountering God: Christian Faith in Turbulent Times (Louisville, KY: Abingdon Press, 2000), 116-117.

${ }^{2}$ Aubrey Malphurs, Value-Driven Leadership (Grand Rapids, MI: Baker Books, 1996), 34 .

${ }^{3}$ John C. Maxwell, Developing the Leader Within You (Nashville, TN: Thomas Nelson Publishers, 1992), 15. 
expect involvement. ${ }^{1}$ Nelson Annan bluntly puts it, "Some churches welcome people the first time they visit, but no other interaction takes place. Newcomers are not challenged to get involved in the church. Eventually they begin attending some other church where they are not only warmly welcomed, but also encouraged to be an active part of the family, not just the recipients of friendly greetings."

It is mentioned thirteen times that pastors should adopt a discipleship training program where they would train a few who in turn would train others. This concept of training was widely practiced by Jesus. He called the twelve disciples and invested time in training them so they could develop leader qualities in others. This category is very important, it is listed eight times. The members are saying to pastors that if they want to equip the laity for ministry, they must be open to dialogue. Counseling in family life is mentioned eight times, and four times it is listed that pastors should establish a library for resource material in equipping the laity. The rest of the categories are presented in table 12.

The purpose of this study was to determine the current practices being used by pastors in the WJC for equipping the laity for ministry. The review of the literature on equipping the laity indicates that there are principles vital to the training of laity for ministry:

'James Cress, "New Members and Their Extended Family," Elder's Digest 8, no. 2 (July-September 2002): 6 .

${ }^{2}$ Nelson Annan, “More People! Is Church Growth Worth It?" Elder's Digest 8, no. 2 (July-September 2002): 7. 
familiarity with the characteristics of self-leadership, leadership qualities, the role of the pastor in the training process, and strategies for training laity.

According to the survey responses from the pastors, most are familiar with personal spiritual growth practices and leadership styles. Many are actively involved in conducting evangelistic meetings. The pastors have a commitment to winning souls and baptizing, but the reported number of follow-up Bible studies and home visitations would indicate that there is a need for a more holistic approach. This would involve the investment of time on the part of the pastors to train and empower the laity so that they then become involved in the various ministries of the church.

The surveys completed by members indicated a desire on the part of the laity to take more time for personal spiritual development. The members did indicate an understanding of how pastors need to lead but felt that the laity could be more involved in the decision-making processes. The members also expressed a desire to have the pastor prioritize the training of the members for ministry. Overall, the responses indicated a need for a better understanding of the role of the pastor in equipping the laity.

\section{Summary}

This chapter has presented a compilation and an in-depth analysis of the surveys done by the pastors and members of the West Jamaica Conference of SDA. In the five major categories of the survey, the data gathered have shown that pastors have to invest more time in self-leadership. Simply put, pastors cannot give what they do not have. If 
pastors are going to carry out their biblical role of equipping the laity for ministry, they will have to invest more time in the area of spiritual discipline.

In the leadership category, pastors and members recognized the importance of developing strong leadership qualities. John Maxwell asserts, "The key to success in any endeavor is the ability to lead successfully. Everything rises and falls on leadership. The effectiveness of your work will never rise above your ability to lead and influence others."1

In the process of making decisions, pastors should think seriously whether or not it is right to decide for the members of their congregation. The conference has a tremendous part to play in supporting the pastor in his/her role to equip the laity. Baptisms are significant, but should not be the primary goal of the conference; a holistic plan for evangelism must be developed from the conference level.

It is imperative that pastors do something about training. The members have really spoken, and the survey shows that the laity place a high premium on training--the kind of training that includes every aspect of the church. The pastors cannot do it alone. The members have suggested what needs to be done. The pastors must now organize the work so that the laity can be equipped and trained for the work of the ministry.

${ }^{1}$ Maxwell, 2. 


\section{CHAPTER 5}

\section{A STRATEGY FOR PASTORS TO EQUIP THE LAITY FOR MINISTRY IN THE WEST JAMAICA CONFERENCE OF SDA}

In 2002, I conducted a survey among the pastors of West Jamaica Conference of SDA to evaluate their role in equipping the laity. Among the thirty-six pastors, eighteen pastors, 50 percent, responded. Six pastors, 33 percent, were dissatisfied with the process of equipping the laity for ministry. Likewise, seven pastors, 39 percent, were uncertain regarding their role in equipping the laity. Only five pastors, 28 percent, stated that they were satisfied with the process of equipping the laity for ministry.

This chapter suggests a strategy for pastors to equip the laity for ministry in the WJC. In order to achieve the desired objectives of this strategy, four seminars will be presented for each group. Each seminar will be conducted over a period of four Sundays. The pastors in the parish of St. James will participate in the first series of four seminars. Next, the pastors in the parish of Hanover and Westmoreland will meet together; and finally, the pastors in the parish of St. Elizabeth will meet for the third series of four seminars. 
The primary reason for having three separate series of seminars is to reduce traveling and enhance personal participation and interaction among these groups of pastors. After these pastors have been equipped from the seminars, they will develop strategies to equip the leaders for ministry.

\section{Defining a Strategy}

What is a strategy and how important is it to develop a strategy to equip the laity for ministry? Aubrey Malphurs defines a strategy as a process that determines how you will accomplish the mission. ${ }^{1}$ He further asks three key questions in the planning of a strategy:

1. What is this strategy supposed to accomplish?

2. What process does it require to be realized?

3. How will this strategy be accomplished?2

A strategy is a chosen means to accomplish a predetermined goal, says C. Peter Wagner. ${ }^{3}$ Others argue that a strategy is something that is optional in human life and activity. It is a practice for unbelievers and is out of bounds in the spiritual realm. Wagner

${ }^{1}$ Aubrey Malphurs, Strategy 2000: Churches Making Disciples for the Next Millennium (Grand Rapids, MI: Kregel Publications, 2000), 44-47.

${ }^{2}$ Ibid.

${ }^{3}$ C. Peter Wagner, Strategies for Church Growth: Tools for Effective. Mission and Evangelism (Ventura, CA: Regal Books, 1987), 24. 
points out that the most comfortable thing in the world is to have no goal, for then there are no failures. ${ }^{1}$ If we aim for nothing, we will certainly hit it.

The Bible says, "We should not be like the horse or like the mule which have no understanding" (Ps 32:9). "For where there is no vision the people perish" (Prov 29:18). A strategy provides focus and direction to a desired goal. That it is why it is extremely important to plan a strategy using the methods and technology that will best accomplish the work. Due to the time constraints of both leaders and laity, developing a strategy is essential. The challenge is how to organize the process and involve as many as possible. If the pastor is able to engage the laity, both must know what to do and how to go about it.

David Hocking argues that the one reason many organizations are unable to accomplish their goals is due to the lack of a proper strategy. Hocking further suggests that a strategy should be developed so that the process by which something is to be accomplished can be clearly outlined. ${ }^{2}$

A strategy gives access to a broader picture and deeper involvement by both the leaders and laity in the church organization. George Bạna emphasizes the importance of a vision that is not only created by the pastor but one that belongs to the congregation. When people know where the church is headed, they are able to convert the vision into a tangible strategy for implementation. Keeping their minds set on the envisioned end result, they

${ }^{1}$ Ibid.

${ }^{2}$ David Hocking, The Seven Laws of Christian Leadership (Ventura, CA: Publications, 1991), 234-235. 
create language, emotions, strategies plans, policies and structures to facilitate their desired outcome. $^{1}$

\section{Developing a Successful Strategy for Equipping the Laity}

Nkosiyabo Zvandasara confirms that an indiscriminate application of even the most proven strategy will not guarantee automatic success. Sensitivity to the particularity of each unique situation elicits a careful contextualization of church principles that might have proven successful elsewhere. $^{2}$

George Barna is quick to point out that every church is faced with an absolutely unique set of circumstances within which it is called to minister. One cannot simply locate a growing church, identify the characteristics of that ministry, and implement a carbon copy with the assumed expectations of success. In America today, every church that wishes to influence and change lives has to be sensitive enough to the needs of that local congregation. $^{3}$

Samuel Rima also warns pastors and leaders to be extremely careful in the selection of strategies. A plan that is successful in one church may not work in another setting. ${ }^{4}$

${ }^{1}$ George Barna, The Power of a Vision (Ventura, CA: Regal Books, 1992), 32.

${ }^{2}$ Nkosiyabo Zvandasara, "Strategic Church Planting in the Central Zimbabwe Conference" (D.Min. dissertation, Andrews University, 1998), 104.

${ }^{3}$ Barna, User Friendly Churches, 87.

${ }^{4}$ Samuel D. Rima, Rethinking the Successful Church: Finding Serenity in God's Sovereignity (Grand Rapids, MI: Baker Books, 2002), 34. 
While the seeker-sensitive model used by Bill Hybels of the Willow Creek Community Church and Rick Warren of the Saddleback Community Church proved to be successful, not all churches who use the seeker-sensitive approach will be guaranteed success. In fact, at the August 2000 Willow Creek Leadership Summit, Bill Hybels suggested that the current seeker-sensitive model has begun to lose its effectiveness and is in need of rethinking for the twenty-first century. ${ }^{1}$

According to Gary McIntosh, "One must always remember that God is the Source of genuine church growth. Instead of focusing of one size fits all models in ministry, the pastor and leader should strive to bring out the best in any size church."”

\section{The First Seminars; Pastoral Self-Leadership}

These seminars for pastors will be organized through the WJC. I will arrange a meeting with the President and other Conference administrators, where a detailed explanation of the strategy for equipping the laity will be outlined. This meeting will also request the cooperation and support from the administrators for the upcoming seminars. Furthermore, a letter will be sent from the President to each pastor informing them about the importance of the seminars.

'Rima, 35.

${ }^{2}$ Gary L. McIntosh, One Size Doesn't Fit All: Bringing Out the Best in Any Size Church (Grand Rapids, MI: Fleming H. Revell, 1999), 10. 
Instructor of the Seminars

The lectures will be presented for one month with each group. After presenting the series, the pastors will begin to develop strategies to equip the laity of their respective churches.

\section{Purpose of the Seminars}

The seminars will highlight the biblical concept of self-leadership with a focus on the life and ministry of Christ. The first series is designed to heighten the awareness and importance of developing the pastor's personal and spiritual growth. It will consider the necessity of caring for the physical, mental, social, and spiritual dimensions, first in the context of Jesus' life and then in the context of their own lives.

The most common lament among leaders is that there is not enough time in a day to do everything that is required and still have time for personal prayer. Bill Hybels describes a scenario where people who are involved in the marketplace are trained to believe that time is money. They cram all that they can into each day, start their day earlier, take work home, check e-mail while they fly, work with their laptop on the commuter trains, phone clients while they drive, and schedule breakfast and lunch appointments for their profit. Performance, performance, performance, performance is the key to promotion to 
compensation and to increased power. However, so much activity leaves little time for quiet moments with God. ${ }^{1}$

George Sweeting points out that we live in a fast-moving noisy world. The pace at which most of us operate is frightening. More than ever before, we need to budget our time to those things that must be done. Because of our hectic schedule, many important activities get lost in the shuffle. Unfortunately, for many Christians, the quiet time does not rank high enough on the list. It becomes a casualty to the clock. The activity that should be most important is put aside, leaving us spiritually weak and unprepared for the battles of daily living. ${ }^{2}$

Despite Jesus' busy schedule, He would turn aside from the scenes of His labor to meditate in the green valley and hold communion with God. The early morning often found Him in a secluded place meditating and searching the Scriptures or in prayer. ${ }^{3}$

Patricia Brown explains the importance of leading from the center, and describes the condition that many leaders experienced:

The souls of leaders hunger and thirst. We sense an inner emptiness, a void, a chasm within ourselves that forever calls out in starvation. The inner ache reminds us that we possess a spirit. Most of the time we neglect this place that is within us. We try to fill the hunger with running meetings, writing memos, and returning calls.

${ }^{1}$ Bill Hybels, Too Busy to Pray: Slowing Down to Be with God (Downers Grove, IL: InterVarsity Press, 1998), 123-124.

${ }^{2}$ George Sweeting, How to Begin the Christian Life (Chicago, IL: Moody Press, 1993), 87.

${ }^{3}$ Ellen G. White, The Desire of Ages (Mountain View, CA: Pacific Press, 1940), 83. 
But every so often the emptiness grabs our attention; it will not be easily ignored. The failure of leaders to deal with their own inner lives is deeply troubling, not only for themselves, but also for others in the misery they create. We cannot continue in this way. We who wish to lead from a spiritual center cannot allow the business managers of the world to set our agenda for leadership. As people longing to uncover the inner journey, we seek guideposts to cultivate the sacredness and depth of everyday lives. How? Through the Spiritwork. ${ }^{1}$

Charles Swindoll describes the result of life on the fast tract: impatience, irritation, anger, longer hours, less and less laughter. No vacations, inflexibility. Greater and greater gaps between meaningful times with God's Word. Precious few if any moments in prayer and prolonged meditation. There is no way that they can keep going at this pace and stay effective year after year. Pastors are human, so they should slow down and give themselves a break. Stop trying to cover all the bases. Allow time to assess their position and if necessary time to heal. ${ }^{2}$

Some good advice from Eugene Habecker suggests that healthy leadership begins with healthy leaders. The advice he gives to leaders is that they should take care of their bodies. ${ }^{3}$ Habecker found out that leaders in many Christian organizations are substantially overweight. There are many reasons why this happens: a frequent and seemingly neverending schedule of travel, dinners, banquets, homemade pies, and cookies. It is very easy

${ }^{1}$ Patricia Brown, Learning to Lead From Your Spiritual Center (Nashville, TN: Abingdon Press, 1996), 73.

${ }^{2}$ Charles R. Swindoll, Start Where You Are (Nashville, TN: Word Publishing, 1999), 2.

${ }^{3}$ Eugene B. Habecker, Rediscovering the Soul of Leadership (Wheaton, IL: SP Publications, 1996), 40, 41. 
for leaders to struggle in those areas. However, adequate rest and exercise are critical for the leader. There is a point when it is wise to stop and have a rest. ${ }^{1}$

Paul's timely reminder is that our bodies are the temple of God, and that the Spirit of God lives in us. If anyone destroys God's temple, God will destroy, for God's temple is sacred, and you are that temple (1 Cor 3:16-17).

Satan will seek to make the servant of God so busy about many things that physical needs are often neglected. This must not be permitted to happen. The minister may set an example in family devotions, but beyond that he needs to spend precious hours alone with God and His Word. This is in addition to the time spent on sermon preparation. Only then will there be an awareness of personal insufficiency and a sense of need for an in-filling of the power for the work of God. ${ }^{2}$ Allister McGrath suggests that one of the dominant themes of Augustine's work is set in the opening paragraph of his address to God. Augustine declares, "You have made us for yourself, and our hearts are restless until we have found our rest in Thee."

When we begin our day with God, we have the physical strength to carry out our responsibilities. When this happens, the physical and spiritual strength will be renewed and

${ }^{1}$ Tbid.

${ }^{2}$ The Seventh-day Adventist Minister's Manual, 22.

${ }^{3}$ Augustine, quoted in Allister E. McGrath, Christian Spirituality (Malden, MA: Blackwell Publishers, 1999), 144. 
we will be able to meet the daily challenges of life. In order for us to guarantee our continuous personal growth as Christians, we must have a regular personal devotional life.

Rest is necessary. Despite our busyness, the Lord longs for us to drop our busyness and simply loll in His lap in adoration and wordless communion. Only God can fill the emptiness and void in our lives.

The social aspect of the pastor's life must include time for family members. It is interesting to discover how in his book entitled Leadership, Rudolph Gulianni talked about devoting time to talk to his mother everyday. At 8 a.m. each day he would look forward to talking with his mother, and his mother always anticipated having that conversation with him. Eventually, talking to each other would make both of them extremely happy. ${ }^{1}$ If an appointment with an earthly parent can be such a happy occasion, how much more would it be to meet each day with our Heavenly Father?

The Minister's Manual also states that the most important concern to the minister must be a personal relationship with Jesus. This can be meaningful only as long as there is a constant devotional life. Unless time is set aside for daily study of the Bible and prayer to sustain the soul, the minister's work will be powerless. ${ }^{2}$ Ellen White expresses the thought so beautifully:

It would be well for us to spend a thoughtful hour each day in contemplation of the life of Christ. We should take it point by point, and let the imagination grasp the scene, especially the closing ones. As we thus dwell upon His great sacrifice for us,

${ }^{1}$ Rudolph W. Gulianni, Leadership (New York: Hyperion, 2002), 29-30.

${ }^{2}$ Seventh-day Adventist Church Manual, 21. 
our confidence in Him will be more constant, our love will be quickened, and we shall be more deeply with His Spirit. ${ }^{1}$

Phillip Samaan agrees with Richard Foster that the imagination is very important in medication. He states that the simple and most basic way to meditate is through the imagination. The use of the imagination enables us to bring the emotion into the equation so that we can come to God with both heart and mind. ${ }^{2}$

Recognizing the gift of leadership carries with it a certain responsibility when it comes to relating to others. It was discovered by George Sweeting that one recognized leader, Andrew Bonar, had three rules to live by:

Rule 1 . Not to speak to any person before speaking to Jesus Christ.

Rule 2. Not to do anything with his hands until he had been on his knees.

Rule 3. Not to read the papers until he had read the Bible. ${ }^{3}$

Leadership is a cooperative process. The Bible teaches that a continuous relationship with God requires the participation of both parties, "Come near to God and $\mathrm{He}$ will come near to you" (Jas 4:8). One way of drawing near to God is through prayer.

Eugene Habeckner makes an insightful comment why leaders need to pray.

Christian leaders of the past have often stated the importance of prayer for the Christian who leads. "Andrew Murry asks, 'What is the reason why many thousands of Christian workers in the world have not a greater influence? Nothing

'White, The Desire of Ages, 90.

${ }^{2}$ Phillip G. Samaan, Christ's Way to Spiritual Growth (Hagerstown, MD: Review and Herald, 1995), 116.

${ }^{3}$ Sweeting, 86 . 
save this- the prayerlessness of their service.... It is nothing but the sin of prayerlessness which is the cause of the lack of a powerful spiritual life." "“Great praying,' wrote E.M.Bounds, 'is the sign and seal of God's great leaders. [A leader] must be preeminently a man of prayer. His heart must graduate in the school of prayer. ... No learning can make up for the failure to pray."

Duewel says it this way: "The foundation on which all ministry and leadership is built is your prayer life. Your leadership is never greater than your prayers."

Wisdom and understanding are both cognitive and emotive. Neal F. McBride suggests that wisdom and understanding are vital to leadership. Just as Solomon requested wisdom when offered any gift, the pastor must pray for the guidance of the Holy Spirit. Pray for insights as you plan. Pray for each member of the group. When it comes to planning and leading your group, and all the other things you do as well, remember that too much prayer is impossible. ${ }^{2}$

It is difficult and sometimes impossible for the church to rise higher than its leaders. Pastors cannot give what they do not have. If the pastors in WJC are going to equip the laity for ministry, they must first equip themselves before they can equip others. This seminar will also highlight a biblical concept of self-leadership, particularly on the life and ministry of Christ and the significant part it plays for an effective pastoral ministry.

${ }^{1}$ Eugene B. Habecker, Leading with a Follower's Heart (Wheaton, IL: SP Publications, 1990), 89.

${ }^{2}$ McBride, 81 . 
TABLE 13

LOCATION AND SCHEDULE OF THE SEMINAR FOR THREE-MONTH TRAINING SEMINARS

\begin{tabular}{|l|l|l|l|l|}
\hline \multicolumn{1}{|c|}{ TIME } & \multicolumn{1}{|c|}{ SUNDAY } & \multicolumn{1}{|c|}{ SUNDAY } & SUNDAY & \multicolumn{1}{c|}{ SUNDAY } \\
\hline $9: 30-10: 30$ & DEVOTIONAL & DEVOTIONAL & DEVOTIONAL & DEVOTIONAL \\
\hline $10: 30-10: 45$ & $\begin{array}{c}\text { WELCOME/ } \\
\text { FELLOWSHIP }\end{array}$ & $\begin{array}{c}\text { WELCOME/ } \\
\text { FELLOWSHIP }\end{array}$ & $\begin{array}{c}\text { WELCOME/ } \\
\text { FELLOWSHIP }\end{array}$ & $\begin{array}{c}\text { WELCOME/ } \\
\text { FELLOWSHIP }\end{array}$ \\
\hline $10: 45-11: 45$ & $\begin{array}{c}\text { SELF- } \\
\text { LEADERSHIP }\end{array}$ & LEADERSHIP & $\begin{array}{c}\text { ROLE OF THE } \\
\text { PASTOR }\end{array}$ & $\begin{array}{l}\text { MODEL TO } \\
\text { EQUIP THE } \\
\text { LAITY }\end{array}$ \\
\hline $11: 45-12: 00$ & DISCUSSION & DISCUSSION & DISCUSSION & DISCUSSION \\
\hline $12: 00-12: 10$ & EVALUATION & EVALUATION & EVALUATION & EVALUATION \\
\hline $12: 10-12: 20$ & BREAK/DRINK & BREAK/DRINK & BREAK/ DRINK & BREAK/DRINK \\
\hline $12: 20-1: 20$ & $\begin{array}{c}\text { SELF- } \\
\text { LEADERSHIP }\end{array}$ & LEADERSHIP & ROLE OF THE & $\begin{array}{c}\text { MODEL TO } \\
\text { EQUP } \\
\text { LAITY }\end{array}$ \\
\hline $1: 20-1: 30$ & DISCUSSION & DISCUSSION & DISCUSSION & DISCUSSION \\
\hline $1: 30-2: 00$ & CHARGE & CHARGE & CHARGE & CHARGE \\
\hline $2: 00-2: 10$ & EVALUATION & EVALUATION & EVALUATION & EVALUATION \\
\hline $2: 10-3: 00$ & DINNER & DINNER & DINNER & DINNER \\
\hline
\end{tabular}


Objectives of the Seminars

The objectives of the seminars are as follows:

1. To define the meaning of self-leadership

2. To identify the self-leadership principles modeled in the life of Christ

3. To explain the role of self-leadership in pastoral ministry today

3. To provide pastors with the strategies for becoming self-directed leaders

4. To train the pastors to equip others for ministry, particularly the laity.

Description of the Seminar

The seminar on self-leadership covers the subjects which clearly define the meaning, importance, challenges, and benefits of self-leadership. The regular format of these series of seminars will include a devotion at the beginning, followed by group discussions, and a short charge at the end. Each session will conclude with an assessment procedure.

\section{Seminar Content}

Suggested Course outline:

1. Introduction
A. Course overview
B. Requirements

2. Biblical and theological basis for self-leadership

A. Definition of self-leadership 
B. Jesus and self-leadership

C. Self-leadership in fasting and prayer life

D. Self-leadership in the study of the Scriptures

3. Ellen G. White and Self-Leadership
A. Fasting and prayer
B. The study of the Scriptures
C. Meditation

4. The Importance of Self-Leadership in the Pastor's Life
A. It leads to total dependence upon God
B. Creates a deep longing for God
C. Enhances devotional life with family
D. Allows time for meditation and relaxation

5. The Benefits of Self-Leadership
A. Ability to cope with the demands of pastoral ministry
B. Provides a more intimate relationship with God
C. Personal time for self and family
D. There is a blessing of rest and satisfaction
E. Develop implicit trust in God. 


\section{The Second Seminar: Pastoral Leadership}

One of the most important qualities in a pastor's ministry is leadership. The problem with many pastors today is that they do not believe that God has called them to be leaders. A survey conducted by George Barna in American churches indicates that these churches are dying from lack of leadership. He further argues that in this time of unprecedented and plentiful resources, the church is actually losing influence. The primary reason is lack of leadership. ${ }^{1}$ An interesting definition of leadership comes from Gary Wills, who defines leadership as mobilizing others towards a goal shared by the leaders and followers. ${ }^{2}$

Leadership has always been difficult, says Leith Anderson. It was not easy for Moses, David, Paul, Martin Luther, or Abraham Lincoln. To understand the problem of leadership will not make it easy, but it will go a long way toward putting the difficulties into perspective. $^{3}$

Larry B. Lewis's point about leadership is poignant: "Leadership is the key in any organization." ${ }^{4}$ Since leadership is the key in any organization, it is critical for pastors to improve their leadership abilities to empower themselves and their members for ministry.

${ }^{1}$ George Barna, Leaders on Leadership: Wisdom, Advice and Encouragement (Ventura, CA: Regal Books, 1997), 18.

${ }^{2}$ Ibid., 21-23.

${ }^{3}$ Leith Anderson, Leadership That Works (Minneapolis, MN: Bethany House Publishers, 1999), 25, 26.

${ }^{4}$ Lewis, 84 . 
According to the research surveys, the members of WJC also emphasized the significance of leadership. They expect the pastor to demonstrate the leadership qualities that enhance the spiritual growth of the church. In the area of decision making, the majority of the members disagree that the pastor should not make every decision for them. In other words, the members would like to know that they are a part of the decision-making process.

Most of the members disagree when the pastor does the work alone. They also want to get involved. While 128 members, 59 percent, want the pastor to get involved in all the activities of the church, 165 members, 76 percent, agree that the pastor should support the overall activities of the church. The members desire their pastor to identify themselves with the plans and activities of the church (see survey on table 9).

The pastors also recognized the importance of leadership in pastoral ministry. Pastors want to be involved; that is why 78 percent of pastors agree that they should be a part of the overall activities of the church. However, fifteen pastors, 83 percent, do not agree that it is better for them to do all the activities of the church (see table 4).

Among the eight characteristics of growing churches that Christian Schwarz presents, Empowering Leadership plays a fundamental role. Leaders of growing churches concentrate on empowering other Christians for ministry. These pastors equip, support, and mentor individuals, enabling them to become all that God wants them to be. ${ }^{1}$

${ }^{1}$ Schwarz, 22. 


\section{5}

Barna also found out in his survey that highly effective churches place great emphasis on leadership. "When a true leader is given the opportunity to lead a church, people's lives are never the same. The entire culture of the church changes because of its pastoral leadership. Such leaders articulate vision, mobilize the people, motivate focused activity, consistently provide strategic direction to get the job done efficiently and effectively--these churches alter history one life at a time."

\section{Purpose of the Seminar}

Leadership plays a significant role in pastoral ministry. The purpose of this seminar is to emphasize the importance of leadership and to further explain its effectiveness in leading God's people and equipping them for ministry. Furthermore, the seminar examines the biblical foundations of leadership. It focuses on the leadership insights of Moses and Joshua in the Old Testament, and Jesus and Paul in the New Testament. Finally, the seminar will conclude with some important qualities in identifying leaders, and suggests some key elements in leadership.

\section{Description of the Seminar}

The second seminar will be focused on Leadership. The same format will be followed as the first; however, the topics and objectives will be different in that these topics will deal specifically with leadership. The seminar will teach pastors the biblical principles

\footnotetext{
'Barna, Habits of Highly Effective Churches, 32.
} 
for developing pastoral leadership. As the pastors understand the important role that leadership plays in ministry, they will be better prepared to equip themselves and the laity for ministry.

\section{Objectives of the Seminars}

The seminars seek to accomplish the following objectives:

1. Examine leadership models and principles in the Old Testament

2.. Explore leadership models and principles in the New Testament

3. Understand the meaning of Christian leadership today

4. Identify key leadership qualities to look for in the selection of leaders

5. Explain the significance of training a successor

6. Explain the impact of leadership on church growth.

\section{Seminar Content}

Course Outline

1. Introduction
A. Course overview
B. Requirements

2. The meaning of Christian leadership

3. Identify models of leadership in the Old Testament
A. Moses
B. Joshua 
4. Explore leadership principles in the New Testament

A Identify key qualities in the Christocentric model of leadership

B. Selection

C. Association

D. Consecration

E. Impartation

F. Demonstration

G Delegation

H. Supervision

I. Reproduction ${ }^{1}$

5. Discover the Pauline model of leadership
A. Training partners in ministry
B. Organizing oikos churches
C. Through spiritual gifts

6. Identify key qualities for selecting leaders,
A. Enthusiasm
B. Testimony
C. Dedication
D. Spirit-filled

${ }^{1}$ Robert E. Coleman, The Master Plan of Evangelism (Grand Rapids, MI: Fleming H. Revell, 1994), 27-116. 
E. Time

7. Feedback

\section{The Third Seminar: The Role of the Pastor in Equipping the Laity}

One of the greatest challenges that pastors face in WJC is to maximize the full potential of the members by equipping them to work in the local churches. The majority of those pastors who responded to the survey were not satisfied with the work they were doing to equip the laity.

The primary reason for the pastors' dissatisfaction is not difficult to understand. A typical pastor is in charge of six to eight churches. Every year each pastor conducts one or two evangelistic crusades, at the same time organizing one or two lay crusades, in addition to his other numerous responsibilities.

Between 1998-2001 there were eighty-two centurions, twelve double centurions, three triple centurions, and one over four hundred in 1999. The Evangelism Coordinator for WJC states, "West Indies Union gave us a goal of fourteen thousand for the quadrennium, 1998-2002. We baptized 16,493."

Evangelism is at the heart of the work in WJC. The pastors in WJC are hard workers and they must be saluted for their evangelistic exploits. But, they are under pressure to reach their baptismal goals.

${ }^{1}$ West Jamaica Conference, “Report of the First Quadrennium," July 2002, 125. 
The members in WJC are also calling on their pastors to equip them to carry out the work of the church. When the members were asked to make suggestions that pastors could use to equip the laity for ministry, training was mentioned 185 times (see table 12).

On April 7 and 8,2002, more than 8,000 Adventists converged on the Orlando, Florida, Convention Center for the NAD Festival of the Laity. ${ }^{1}$ This meeting provided the opportunity for the church members in North America to sharpen, develop, and update the skills necessary for providing effective ministry for the Lord. The director opened the convention by addressing the delegates, "We have come together under the mandate of the Holy Ghost, to network and further equip, train, and inspire ourselves to use our spiritual gifts in our God-given ministries to help finish the work." The last meeting they had of this nature was fifty-one years ago. ${ }^{2}$

Jesus is the Master Equipper. Mark says, "And He went up to the mountain and called to Him those He himself wanted. And they came to Him. Then He appointed twelve, that they might be with Him and that He might send them out to preach, and to have power to heal sicknesses, and to cast out demons" (Mark 16:13-15).

The first step in the "equipping ministry" of Jesus was a call that the disciples "might be with Him." They could not preach, teach, or heal until they had been "with Him." The assurance of His presence, power, love, and acceptance was essential to the equipping strategy of Jesus (John 15:5). The disciples needed to observe Christ's attitudes and

'Olson Perry, "Festival of the Laity," Lake Union Herald, June 2002, 6-7. ${ }^{2}$ Tbid. 
motivations before they could do effective ministry. Jesus made it clear that everyone who is perfectly trained will become like his teacher (Luke 6:40).

Therefore, it is urgent for a holistic program of evangelism to be developed, and that is why Russell Burrill is calling for a revolution in the SDA Church with particular concerns in North America. Burrill is calling on all pastors in the Adventist churches to return to their biblical job description. The role of the pastor is not to give primary care, but to equip and train the laity for ministry. ${ }^{1}$

Another strong advocate of the call for pastors and leaders to train other leaders is George Barna. He argues that many churches have unrealistic expectations of their pastors. These churches expect their pastors to be "jack of all trades" and master of none. The research of Barna shows that among a dozen type of professionals, pastors are the most frustrated of the lot, typically feeling guilt, stress, and disappointment due to their inability to fulfill the demands placed upon them by their flock. Why are some pastors unwilling to equip the laity? He cites some possible reasons:

1. To retain power and control

2. A feeling of insecurity

3. A struggle with ego and self-image. ${ }^{2}$

Eric Perez points out that there are three pastoral models. The first model is the pastor who wants to do everything for the members. The second model is the pastor who

'Burrill, Revolution in the Church, 46-49.

${ }^{2}$ Barna, Habits of Highly Effective Churches, 37-41. 
wants the members to do everything for him, and the third model is the pastor who is willing to work together with the members to fulfill God's work. ${ }^{1}$

A survey was conducted by Kenaope Kenaope in his conference in Botswana. He found out that 67 percent of the respondents viewed their pastors as shepherds, while 19 percent recognized them as equippers. Kenaope encourages the pastors to teach the members that the work of the pastors is to equip the body of Christ for service, not to be care providers only. ${ }^{2}$

Ellen White has written countless advice to pastors, instructing them to make training their priority. "The best thing the pastors can do for the members is not sermonizing but educating and planning work for them to do." "Let ministers teach church members, that in order to grow spiritually they must carry the burden that the Lord has laid upon them. God has not given His ministers the work of setting the church right. No sooner is this work done, than it has to be done over again. Church members that are thus looked after and labored for become religious weaklings."

Sometimes ministers do too much, they seek to embrace the whole work in their arms. It absorbs and dwarfs them, yet they continue to grasp it all. They seem to

'Eric G. Perez, "Pastoral Models,” Essay Classification, 24 September 2002, 1-2.

${ }^{2}$ Kenaope Kenoape, "The Factors That Influence Church Growth in Botswana" (D.Min. dissertation, Andrews University, 2003), 104.

${ }^{3}$ Ellen G. White, Christian Service (Washington, DC: Review and Herald, 1947), 69.

${ }^{4}$ White, Testimonies for the Church, 7:19. 
think that they alone are to work in the cause of God, while members of the church stand idle. This is not God's order at all.'

\section{Purpose of the Seminar}

The work of the pastor is a challenging and demanding responsibility. In an effort to face the challenges of ministry, many pastors do the work single-handedly. It is fully time that pastors recognize that they cannot do it alone. Furthermore, they cannot abdicate their responsibility. They must recognize that their job description is to equip and train the laity for ministry. The purpose of the seminar is to emphasize the importance of equipping the laity for ministry.

\section{Description of the Seminar}

The seminars will be conducted for the duration of time like the others. The format will follow the same pattern. There will be lectures, discussions, and various interesting subjects on the role of the pastor in equipping the laity for ministry.

\section{Objectives of the Seminars}

The seminars will meet the following objectives:

1. Examine the Old Testament models of equipping

2. Discover the New Testament models of equipping

3. Discuss the role of the laity in early Adventism in Jamaica

${ }^{1}$ White, Evangelism, 113. 
3. Explain the biblical role of the pastor

4. Discover the biblical role of the laity

5. Examine equipping in E. G. White's writings

6. Explore equipping in early Adventism

7. Discover the benefits of equipping.

\section{Seminar Content}

Suggested course outline

1. Introduction
A. Course overview
B. Requirements

2. Examine the Old Testament model of equipping
A. Mosaic Model of equipping
B. Joshua

3. Discover Jesus' Model of Equipping
A. Jesus' model of equipping
B. The calling of His disciples
C. Developed relationship with His disciples
D. Training His disciples
F. The sending out of His disciples

4 The Early Church and Equipping 

A. Small groups and equipping
B. Paul's concept of equipping

5. Ellen G. White and Equipping the Laity
A E. G. White's priority on equipping
B. Views on equipping given to pastors
C. Views on equipping shared with the members

6 Equipping in Early Adventism
A. Attitude of leadership towards equipping
B. Primary work of the pastors
C. Primary work of members

$7 \quad$ Result of Equipping the Laity
A. Pastors' return to their biblical role
B Members serve in their area of giftedness
C. Church should be a vibrant, happy church
D. Members care for one another
E. Membership should increase

8. Feedback

\section{The Fourth Seminar: A Model to Equip the Laity}

The purpose of this seminar is to evaluate the suggestions that the members gave and use the data to develop a strategy to equip the laity for ministry. It is important to 
examine those suggestions because pastors need to know what the members are saying if they are going to plan the right strategy. Now that the pastors want to incorporate training as an integral part of their ministry, they must know what area of training the members need. The surveys shown in table 12 specify the areas of concentration.

\section{Description of the Seminar}

This final seminar will follow the same format as the previous three. However, it will be more like a workshop where pastors will discuss how they are going to develop their strategy to equip their leader for ministry. I will discuss the data with the pastors so that they can be aware to develop and implement strategies to equip the laity. The members were asked to give suggestions that are valuable to pastors in equipping the laity. This seminar will evaluate the suggestions from the laity. I will suggest a model to the pastors and discuss ways how they will implement this model to equip the laity for ministry.

\section{Purpose of the Seminar}

The role of a leader is not just to lead, but to recruit and train other leaders. Byron Rush resonates with this kind leadership when he states that a leader's job is not completed until followers have taken his place. ${ }^{1}$

Giving ministry and leadership away is essential. It should be the goal of each local pastor to organize, mobilize, and equip the members of the churches. The pastor's role of

${ }^{1}$ Myron Rush, The New Leader: A Revolutionary Approach to Leadership (Colorado Springs, CO: Victor Books, 1989), 132, 133. 
facilitator will involve this continuous process of equipping leaders to succeed one another. Paul instructed Timothy, "Those things you heard me say in the presence of many witnesses, entrust to reliable men who will be qualified to teach others" (Eph 4:11-13).

This ministry of multiplying leaders is God's way of providing for the kind of guidance and stability that is needed for the church. Proven men are to train others to minister, and those in turn train others.

Douglas Johnson suggests that perhaps the ultimate test as a leader is to train others to do jobs that you normally do. Think about the consequences of training others. They will take your jobs and leave you to do ... what? Develop new interests and skills. You will find yourself listening to their ideas and using some of them because they will be as good or better than yours. ${ }^{1}$

Supporting the view to empower other leaders in the church, Carl George states that in order to provide enough preventive care at the grassroots level, a church must systematically tap into the most valuable and plentiful resource: the potential leaders among the lay people. ${ }^{2}$

Jesus spent most of His time with twelve men, fishermen, tax collectors, and a handful of women. While He was with them for three years, they were undependable, slow to learn, and at times self-absorbed. Yet Jesus' plan was to disciple these few

'Douglas W. Johnson, Don't Know Much About Being a Leader in My Church (Nashville, TN: Abingdon Press, 1996), 60.

${ }^{2}$ George, The Coming Church Revolution, 48, 49. 
followers and then to turn them loose to take the most important message of all time to the entire world.

Michael Mack concludes, "Jesus spent some time with the multitudes, but he concentrated on the smaller groups, particularly the twelve, and especially the three--Peter, James, and John. This is the genius of Jesus' strategy. By spending time intensely discipling a few, they would be equipped to multiply his message over and over again." Gone are the days, says George Gladis, when pastors feel they are the only ones who know what is best for the church. ${ }^{2}$

One of the marks of a highly innovative and life-filled church is the giving away of ministry to the people in ways that resemble the ministry of the early church.

Gladis puts it ths way:

The church in the post-modern world must return the ministry to the people. The church began as a populist movement led by a servant-messiah who crossed the religious authorities to bring genuine faith back to the people. If churches are to have meaning in the post-modern world, it will be because they are filled with people who have experienced that populist meaning, claimed it, and are willing to live it in the world. The clergy must go out of the way of the people and encourage them on. ${ }^{3}$

Paul Benhare and Brian Harris, in examining the pastor's role, state that for the past century, many churches and pastors have viewed the role and function of the pastor

\section{8,39 .}

'Michael C. Mack, The Strategy Church (Grand Rapids, MI: Baker Books, 1996),

${ }^{2}$ Gladis, 123.

${ }^{3}$ Ibid., 124. 
improperly. He is seen as the minister, the president of the corporation, the benevolent dictator, the chaplain who renders service to his clients, the paid performer, the professional Christian. All these views stand in opposition to Scripture. Every Christian leader must constantly strive to keep his people from being overly dependent on him. He must strive to equip the saints to minister to each other and keep their primary loyalty centered on Christ. ${ }^{1}$

If a church is going to be the training base for ministry, then someone must take the initiative for training, and this is often the responsibility of the elder, but more specifically, the pastor. Alberto Timm reported an example of training lay-leaders in Northeast Brazil. He first chose three elders to train for six months in a special leadership program known as "spiritual multiplication." The participants took two hours of instruction and then participated in visitation each week.

After the first two months of training, each of the leaders chose another set of three potential leaders for training and discipling, replicating the pastor's work in training them. This process will continue until all the members are equipped for ministry. ${ }^{2}$ See figure 1.

$$
\begin{gathered}
\mathrm{P}=\text { Pastor } \quad \mathrm{EL}=\text { Elder } \quad \mathrm{NL}=\mathrm{New} \text { Leader } \\
\mathrm{EL}=\mathrm{NL}=\mathrm{NL}=\mathrm{NL} \quad \mathrm{EL}=\mathrm{NL}=\mathrm{NL}=\mathrm{NL} \quad \mathrm{EL}=\mathrm{NL}=\mathrm{NL}=\mathrm{NL}
\end{gathered}
$$

Figure 1. Timm's spiritual multiplication, leadership training program.

${ }^{1}$ Paul N. Benware and Brian Harris, A Workbook for Discovering and Developing Church Leaders (Chicago, IL: Moody Press, 1991), 8.

${ }^{2}$ Alberto R. Timm, "Reviving Inactive Churches," Ministry, February 1992, 13-15. 
The members were asked to give valuable suggestions to pastors to equip the laity for ministry. The conviction among the respondents of the survey reveals that training was their priority (see table 12). To identify a few examples, training to conduct Bible studies, preaching, and house-to-house visitation was mentioned 185 times, training in small groups was repeated forty-eight times, spiritual disciplines such as prayer and fasting twenty-six times, training to teach forty-one times, and training in leadership twenty-six times.

\section{Developing a Strategy to Equip the Laity for Ministry}

Can an effective model be developed to train the laity for ministry? I would suggest a small-group model for the pastor to use to equip the laity for ministry in the WJC. A careful examination of the models of training reveals that small groups were used effectively by the following persons or groups:

1. Moses used a small group model to equip the Israelites (Exod 18:13-26).

2. Jesus utilized a small group to equip the twelve disciples (Luke 6:12-15).

3. The early church used small groups effectively to spread the gospel (Acts 2:4247).

4. Ellen White was a strong advocate of small-group meetings. She strongly advocates: "The formation of small companies as a basis of Christian effort is a plan that has been presented to me by One who cannot err. If there is a large number in the church, let 
the members be formed into small companies, to work not only for the church members but for unbelievers as well."'1

5. The early Adventist church used small groups for the growth and expansion of the early movement. The small-group movement in Methodism also had an impact on the Seventh-day Adventist Church because of the influence of Ellen White. She recognized the positive spiritual benefits of small-group ministry. As a result she wrote: "Preach less and educate more, by holding Bible-readings and by praying with families and little companies. ${ }^{2}$

The pastors will organize the members into small groups based on the area of their interest. For example, for those members who are interested to be trained to conduct Bible studies, a group or groups will be formed. Another group will be formed for those who would like to do visitation. A leader from each group will be selected to be trained by the pastor, after which that leader will return to that particular group to train them in the specific areas of need.

James Cress makes an interesting point about forming a small group. He argues that if a small group is going to be organized to study without applying the principles, they are just going through mental gymnastics. ${ }^{3}$ Paul Yonggi Cho believes that it is useless to organize a church into small groups if they are not focused on evangelism. He challenges

${ }^{1}$ White, Evangelism, 115.

${ }^{2}$ White, Gospel Workers, 193.

${ }^{3}$ Cress, You Can Keep Them If You Care, 56. 
each of his Bible study groups to set a goal by adding four new persons each year. When each group reaches fifteen, it divides. Each new group seeks to add another four. ${ }^{1}$

A brief description of the Cho strategy was given by Joel Comiskey. He explains that there are 24 districts, organized geographically, who served as the nerve for the church. Each district has paid staff who are available to counsel, encourage, or just be a friend to those in their district. Each district is further divided into 12 to 23 sub-districts, and each sub-district contains 10-15 sections. Each section of 5 to 15 home cell groups and each home cell group has approximately 5 to 10 households. ${ }^{2}$ This strategy has made the Yoiddo Full Gospel Church the largest in the world.

\section{Definition of a Small Group}

A small group is a cell within the church with an ideal size of eight to fifteen people who meet together on a regular basis for worship, Bible Study, outreach, discipleship, and prayer. ${ }^{3}$ McBride points out that a small group is a voluntary, intentional gathering of three to twelve people regularly meeting together with a shared goal of mutual Christian edification and fellowship. ${ }^{4}$

${ }^{1}$ Cho, 82,83 .

${ }^{2}$ Joel Comiskey, Reap the Harvest (Houston, TX: Touch Publications, 1999), 41.

${ }^{3}$ Gregory Lawson, "The Utilization of Home Cell Groups in Leadership Development and Local Church Ministry," Christian Educational Journal 8, no. 3 (Spring 1993): 67.

${ }^{4}$ McBride, 24. 


\section{Keys to a Successful Small Group}

There are certain core values that a small group should possess if it is going to be successful. Here are four important areas:

1. God-to-person relationship-The group should focus on what God wants to happen to the individual members and be sensitive to His touch in their lives.

2. Person-to-God relationship-Group members must be aware of the Holy Spirit touching the lives of each member. As the Holy Spirit impresses, great things will be accomplished for God.

3. Person to person-The response of members to God will affect the way they respond to each other. As the members relate to each other and pray for each other, the support for each will grow stronger.

4. Person to the world-A group cannot maintain its vertical relationship if it does not reach out horizontally.

In the Marietta Church, James Cress developed a practical application of the plan to evangelize the church: (1) Bible study--time in the Word, (2) Prayer--communication with God, (3) Fellowship--interaction with other believers, (4) Witnessing-sharing with others what God has done in the personal life of the believer, and (5) Obedience-applying intellectual understanding into daily life. ${ }^{1}$

${ }^{1}$ Cress, You Can Keep Them If You Care, 56, 57. 
Jesus' instruction for the healing of the demoniac was not to seek a deeper theological understanding or even to isolate himself from others. His first act of obedience was to go and tell his friends what wonderful things God had done for him (Mark 5). Believers need to learn what God wants to teach them by studying His words; however, obedience begins by telling others what God has done.

\section{Small Groups in Acts 2}

Acts 2 gives a succinct description of the activities of small groups in the early church. The members devoted themselves to the apostles' doctrine, that is Bible study. They also had fellowship, that is personal sharing and social interaction. They met for prayer and the breaking of bread together. The result was that the Lord added to the church daily those who were being saved (Acts 2:42-47). Based on the format of small groups in the early church, Johnson developed five common components of the early church:

Loving-Listening and sharing one's testimony

Learning-Studying the Bible and other materials together

Deciding-Making decisions which are in the best interest of each other

Doing-Fulfilling the outreach mission of the group

Praying--Interceding to God for each other. ${ }^{1}$

Prayer is the lifeblood of the small group. Prayer bonds group members

'Johnson, Small Groups for the End-time, 76. 
together, strengthens members for daily life, and undergirds the working of the Holy Spirit. Prayer strengthens group relationships, assists members in developing a devotional life, enables members to minister to one another, and builds faith as members see God meeting the daily needs of the group. ${ }^{1}$

\section{Types of Small Groups}

There are many different types of small groups. Each group is organized to address a particular need. Below is a list of small groups and the specific function they perform:

1. Fellowship group-This group is designed for social interaction. It caters to the social aspects and promotes fellowship and camaraderie between the members.

Sometimes, this group can be so involved in social activities that Bible study and prayer are overlooked.

2. Bible Study groups-The Bible study group is organized for those who want to study the Bible and other books in order to increase their knowledge about God. Consequently, the members share their faith with others.

3. Outreach groups-The members of this group are specifically organized to reach out to members who are not attending and to people who are not Christian.

4. Support groups-Support groups are designed to relate to specific needs such as divorce, grief recovery, addiction to drugs, and smoking.

${ }^{1}$ Ibid., 80. 
5. Prayer groups-Prayer groups spend most of their time praying. This group organizes prayer chains and networks, and they are willing to pray for those situations and circumstances that come to their attention.

6. Covenant groups-This group makes an agreement among each other that they will hold each other accountable to whatever decisions they make.

7. House groups-This group is comprised of members who meet in a home rather than a church setting. Sometimes this group tends to isolate itself from the larger community.

\section{Conditions Needed for the Growth of Small Groups}

Small groups cannot take for granted that once they are organized they will automatically succeed. Certain conditions are necessary for small groups to grow. Usually, small groups meet in a home or in places where distractions are avoided. The seating arrangements are done in a circular pattern to encourage interaction. The meetings are held at a convenient time for the members, so that each member can attend. The members must decide how regular they should meet, whether it is once per week or once every two weeks.

It is also important to decide the length of each meeting, usually sixty to ninety minutes in length. The meeting must begin and close on time. The leader should avoid lectures and plan the meeting so that he/she becomes a facilitator. The focus of the meeting must be directed to Bible study, developing interpersonal relationships, and the application 
of Bible knowledge to everyday lives. Whenever the group reaches more than fifteen to twenty members, it should sub-divide into another group. Group members must be kind, loving, and understanding with each other. Members must remember the golden rule: "Treat others as you want yourself to be treated" (Matt 7:12).

Importance of the Leader of the Small Group

According to Ron Nicholas, without adequate leadership a small group is doomed. Without a wise loving leader, a group may suffer from inhibited beginnings, stunted growth, and accelerated demise. Good leadership unlocks small-group potential. ${ }^{1}$ Johnson interestingly designed an acronym, FAT, in the selection of a small group leader. The F stands for Faithfulness to God, A means Available to meet the needs of the group members, and T means Teachable and willing to learn. ${ }^{2}$

\section{Qualifications of the Leader}

Here are some of the qualifications of the leader:

1. A growing relationship with Jesus

2. A commitment to care for people

3. A passion for winning lost people to Jesus

4. A student of the Bible

${ }^{1}$ Steve Barker et al., Good Things Come in Small Groups (Downers Grove, IL: InterVarsity Press, 1985), 38.

${ }^{2}$ Kurt Johnson, 115. 

5. A teachable person
6. A desire to serve others
7. Commitment to schedule time.

\section{Leadership Styles}

Leadership styles vary from person to person. Understanding how a leader functions will determine his/her ability to facilitate the group. Traditionally, there are four basic leadership styles:

1. The Autocratic leader-The autocratic leader is a person who is a domineering and dictatorial person. This leader attempts to be in total control of the members. He/she makes decisions unilaterally and disregards other viewpoints.

2. Authoritative leader-The authoritative leader has a definite direction in mind, but is open to the ideas of others. The leader usually has strong control, yet the members are actively involved in discussing the leader's goals and ideas.

3. Democratic leader-The democratic leader is group centered, and shares control with the group. The leader is assertive, yet values the abilities and opinions of others.

4. Laissez-faire leader-The laissez-faire leader is the one who is permissive and passive. This leader has no control and allows things to drift.

There are two other leadership styles such as the servant-leader, which is exemplified in the life of Christ. Jesus became a servant-leader when He washed the disciples' feet (John 13:4-9). Jesus also showed His disciples that if they wanted to be 
great, they must become slaves, and if they wanted to be first, they must be last (Matt 20:26-28). The situational leadership is the style that will vary depending on the situation and circumstances.

\section{Leadership Meeting of Small Groups}

It is important to conduct regular leadership meetings, especially at the beginning of the small groups. This meeting helps to evaluate the progress of the group. It also serves as an opportunity to share the joys, frustrations, and challenges of the group. It is also time to discuss problems that may have developed in the group. The hope is that early intervention will contribute to finding a solution. This is also a great opportunity for the leaders to meet and pray together.

Having examined some of the dynamics of the small group, it is important to present an outline for this seminar.

\section{Seminar Content}

Developing a Model to Equip the Laity for Ministry

1. A. Self-leadership

B. Leadership

C. Equipping the laity for ministry

D. A Model for Training the Laity

2. A. Using small groups in equipping the laity

B. Equip them to conduct Bible study 
C. Equip them to preach

D. Equip them to do visitation

E. Equip them to develop leadership qualities

3. A Basic Overview of Small Groups
A. Defining a small group
B. Keys to a successful small group
C. Small groups in the book of Acts
D. Types of small groups
E. Conditions that build a small group

4. Importance of the Leader in a Small Group
A. Qualifications of the leader
B. Leadership styles
C. Leadership meeting in a small group

5. Evaluation

Expected Results of the Seminar

The following results are expected from the seminar:

1. A deeper and more personal relationship with Jesus

2. Improved spiritual disciplines among the participants of the seminars

3. Available resources to train the leaders and laity for ministry

4. A strategy will developed to train the laity for ministry 
5. Pastors will recognize that their biblical role is to equip the laity.

\section{Consecration/Award Service}

At the conclusion of the seminars, the pastors from throughout the WJC will participate in a consecration service. The Personal Ministry Director of the West Indies Union will be invited to speak for this special service. I will give an overview of the program. Pastors will be asked to give testimony as to what they have learned and what they plan to implement among the leaders/laity.

A word of thanks and appreciation will be given to the conference, pastors, and other individuals who helped to organize the seminars. The pastors will be presented with a plaque in appreciation for their participation. This service will act as a motivation for the pastors to equip the laity. Whenever these pastors have completed training their leaders, they too will organize a service to mobilize the leaders/laity for ministry.

\section{Assessment}

At the conclusion of the seminars, an evaluation sheet will be completed by the participants. The purpose of the evaluation is to determine how well the participants accomplished the requirements of the course. Furthermore, it will seek to offer positive feedback that may be critical in planning for the future. The evaluation will be carefully analyzed to ensure that resources are fully maximized. 


\section{Summary}

This chapter has presented a strategy that pastors in WJC can use personally to equip the members for ministry. This strategy is important because it not only focuses on the members alone, but it prepares the pastors with the necessary skills to equip the laity for ministry. However, the process of equipping does not stop at the end of the seminar. The pastor must now accept the responsibility to work with the laity and equip them for the ministry. This is a tremendous responsibility. It will require planning, organizing, and cooperation to accomplish the desired objectives of the strategy.

Furthermore, a model must be developed to equip the laity for ministry in WJC. The small-group model would be the most effective, because the members can be organized into various small groups based on their desire to be trained, thus allowing a greater number of small groups to be formed, and many more members will be equipped in a diversity of ministries. Perhaps the difference between success in ministry and "business as usual" lies not only in designing a strategy but by setting up checks and balances to preserve the momentum the seminars initiate. 


\section{CHAPTER 6}

\section{SUMMARY, CONCLUSIONS, AND RECOMMENDATIONS}

\section{Summary}

The role of the pastor to equip and train the laity for ministry is a challenging and demanding responsibility. It requires planning, perseverance, hard work, and determination. The pastors in the Seventh-day Adventist Church, and specifically the West Jamaica Conference, cannot work effectively by exercising a monopoly over God's work. The pastors must develop a working relationship with the laity and equip them for the mission of the church.

The pastor in charge of the largest church in the world attempted to do everything alone. The result of his effort was devastating; however, God saved his life. He finally discovered, after much opposition from the men, that the secret to his success in building the largest church was in mobilizing and equipping the women of the church for ministry. ${ }^{1}$

Every member of the church has an integral part to play in fulfilling its mission. Simply put, the pastor cannot work alone. This conclusion was drawn many decades ago by Ellen White who stated, "The work of God on earth can never be finished until the men

${ }^{1}$ Choi, 7-12. 
and women comprising our church membership rally to the work and unite their effort with those of ministers and church officers." The focus of this dissertation seeks to address one critical question, Whose role is it to equip the laity for ministry? Is it the pastor's responsibility to equip and train the laity for ministry?

The biblical injunction regarding the role of the pastor is clear. Pastors are called to prepare (equip) God's people for His service (Eph 4:12, NIV). The organization, training, and mobilization of the laity rest in the hands of the pastor. Pastors cannot abdicate their responsibility. Their biblical job description is to equip the laity for ministry.

Chapter 1 of this dissertation focused on the statement of the problem, purpose of the dissertation, justification of the dissertation, definition of terms, methodology, limitations of the study, and the expectations of the dissertation.

Chapter 2 presented a brief historical background of Jamaica, along with the birth, expansion, and organization of Adventism.

Chapter 3 examined the biblical and theological models of equipping, with special emphasis on the Mosaic model in the Old Testament and the Christocentric model of equipping in the New Testament. This chapter also dealt with equipping the laity in the early apostolic church, the Pauline writings, the writings of Ellen White, and early Adventism.

${ }^{1}$ White, Gospel Workers, 351, 352. 
Chapter 4 compiled and analyzed the surveys that were completed by the pastors and members in the WJC. The pastor's survey sought to address the following areas:

1. Pastor's profile and personal evaluation

2. Pastor's understanding of his/her leadership role

3. Pastor's relationship to the conference

4. Pastor's understanding of his/her ministry

5. Suggestions from pastors to equip the laity.

The surveys of the members in WJC focused on the following areas:

1. Members' profile

2. Members' understanding of pastoral leadership

3. Members and their understanding of church ministry

4. Members' evaluation of their personal ministry

5. Suggestions pastors can use to equip the laity.

Chapter 5 presented a suggested strategy to equip the pastors and members in

WJC. The topics in the seminars are as follows:

1 Self-leadership of the pastor

2. Pastoral leadership

3. The role of the pastor in equipping the laity

4. Areas in equipping the laity. 


\section{Conclusions}

Equipping the laity for ministry is one of the most challenging tasks that pastors are called to do, but it can be done. The artificial barriers between the pastors and the members must be eliminated. Some pastors give the impression that they possess a designated domain in the church, which the members should not cross. Some members believe that some work in the church belongs to the pastor and that they are incapable of performing it. These walls that sometimes divide pastors and members must be broken down.

In the New Testament church, there was no distinction between pastors and members. Everyone was referred to "as the people of God." Each member served as a part of a community and together reached out to others. Today, the church has changed dramatically, and in some congregations there is a chasm between the pastor and the members. The majority of the members have become spectators and are content to allow the pastor to carry out the functions of the church. When this happens, the pastor then suffers from "super star" syndrome.

This polarization of members and pastors within the church may be one of the contributing factors hindering the growth of the church. The work of the church must be shared by all the members. The time has come for pastors to utilize the greatest resource God has given to His church--the members. They are willing to work, but they need to be equipped. It is time to recognize that the biblical role of the pastor is to equip the members for the ministry. 


\section{Recommendations}

The following recommendations have resulted from this research.

1. The West Indies Union of Seventh-day Adventists needs to sponsor more training programs such as seminars and workshops to equip pastors.

2. The West Indies Union needs to give the local conferences the autonomy to set their baptismal goals instead of handing it down.

3. The West Indies Union/West Jamaica Conference should not reward only pastors who have many baptisms, but those who create strategies to conserve the members and train them to make disciples.

4. The West Jamaica Conference needs to develop a holistic evangelistic program which focuses on preparation, baptism, assimilation, and follow-up of newly baptized members.

5. The West Jamaica Conference needs to sponsor more training programs in areas such as Spiritual Disciplines, Leadership, and Equipping the Laity for Ministry.

6. The West Jamaica Conference should meet with the pastors and develop strategies of evangelism that will suit the local churches.

7. The pastors in the West Jamaica Conference need to meet with the members of the local churches so that they too can be given a chance to set their baptismal goals.

8. The pastors need to conduct more training programs and seminars in their local churches. 
9. The West Jamaica Conference should conduct a quarterly evaluation with the pastors to find out how they are equipping the laity for ministry.

10. Northern Caribbean University should place more emphasis in its curriculum on Spiritual Disciplines, Leadership, and the role of the pastor in equipping the laity for ministry. 
APPENDIX A

SEMINAR ON SELF-LEADERSHIP 


\section{APPENDIX A}

\section{SEMINAR ON SELF-LEADERSHIP}

PARTICIPANTS : Administrators, pastors and interns of WJC.

TIME: Sundays, $9: 30 \mathrm{am}-3: 00 \mathrm{pm}$

LESSON OBJECTIVE: The aim of this seminar is to identify the characteristics of self-leadership, explore self-leadership as seen in the lives of biblical characters, and discuss practical applications needed in the lives of the pastors if they are going to equip the laity in the WJC.

SAMPLE MODULE:

Opening: Season of prayer

Presentation:

I. Concept of self-leadership

A. Identifying characteristics

1. Personal relationship with God

a. Prayer

b. Bible study

c. Meditation

d. Fasting

2. Locus of control is internal

B. An ability to do self-referencing with God as the center: 9T, p. 110

II. Biblical examples for self-leadership

A. Moses and self-leadership

1. Time out for training: Exodus $3: 1-3$

2. Facilitating the assignment of tasks: Exodus 18:18-25 
B. Jesus and self-leadership

1. Prayer: Mark 1:35

a. Jesus consistently invested time in prayer (Mark1:35)

b. Jesus prayed in the Garden of Gethsemane (Luke 22:39-46) Matt.27:36-43, Mark 14:32-39

c. Jesus prayed for Himself (John 17:1-5)

d. Jesus prayed for His disciples (John 17:6-19)

e. Jesus prayed for all believers (John 17:20-26)

2. Study of the Scriptures: Luke 2:46-48

a. At age 12 Jesus baffled the teachers of the law with His knowledge of the Scriptures (Luke 2:46-48)

b. Jesus overcame the temptations by using the Scriptures(Matt4:4-10)

3. Meditation: Jesus separated from others and meditated (Luke 2:42-44)

4. Fasting

a. Abstinence: Jesus spent forty days and nights fasting (Matthew 4-10)

b. Helping others

C. Ellen White and self-leadership

1. Prayer: 9T, p. 110

2. Study of the Scriptures: GC, p. 598

3. Meditation: DA, pp: 90,$91 ; \mathrm{MH}$, p. 58

4. Fasting: 4T, pp. 535, 536

Discussion

The pastors are to be divided into groups. The assignments for each group will include a facilitator, recorder, and reporter. (1) One group will be given the assignment to note ideas and practices they have found helpful in fulfilling their own personal need for communion with God. (2) A second group could discuss the benefits to the pastor's family if the pastor is a self-directed leader. (3) Another group will discuss practical ways in which to share self-directed leadership with others. The results could be written on poster boards and set up for a response and additions from the other groups. At the conclusion, the reporter from each group shares with everyone. 
Closing remarks and closing prayer 
APPENDIX B

SEMINAR IN PASTORAL LEADERSHIP 


\section{APPENDIX B}

\section{SEMINAR ON PASTORAL LEADERSHIP}

PARTICIPANTS: Administrators, pastors, and interns

TIME: Sunday 9:30 a.m. $-3: 00$ p.m.

LESSON OBJECTIVE: This presentation will explore different models of leadership and identify key leadership qualities in equipping leaders

SAMPLE MODULE:

Opening: Season of prayer

Presentation:

I. Definition of leadership
A. Leadership is influence
B. Vision: Seeing the invisible beyond the visible
C. Mobilizing others

II. Models of Leadership in the Old Testament
A. Moses' failure to succeed as an autocratic leader (Ex.18:13-15)
B. Jethro shares equipping strategy with Moses (Ex. 18-18-23)
C. Moses' implementation of the strategy worked successfully (Ex.18-24-26)

III. Jesus' Model of Leadership in the New Testament

A. Robert Coleman's seven key characteristics of Jesus' leadership

1. Association-Jesus trained His disciples by associating with them

a. Sitting together: Matthew 5:1

b. On the mountainside: Matthew 5:1

c. By the sea: Luke 5:1-5

d. Walking: Luke 6:1-10 
2. Consecration-Jesus daily surrendered Himself to His Father
a. Self must be denied: Matt. 16:24-26
b. Carry the cross daily: Luke 9:23-25
c. Be a servant: John 12:26-27

3. Impartation-Jesus' methods: concepts, principles, and instructions

a. Holy Spirit as the teacher: Matthew 10:19-20; Luke 12:12

b. Parables and practical examples: Matthew 11, 13

4. Demonstration-Jesus modeled what He taught the disciples
a. Prayer: Luke 11:1-4
b. Love: Matthew 5:43-48
c. Forgiveness: Luke 17:3
c. Witnessing: Matthew $28: 19,20$

5. Delegation-Jesus delegated responsibilities to the disciples
a. Authority: Mark 6:7, Luke 9:1, 2
b. Empowerment: Matthew 10:1

6. Supervision-Accountability was an important part of Jesus' ministry
a. Disciples reported: Mark 6:30; Luke 19:10
b. Particular about details: John 6:1-13

7. Reproduction-Jesus expected His disciples to bring people to Him
a. Discipling: Matt. 28:19-20
b. Preaching, sharing, growing followers: Mark 16:15-18

IV. Pauline Model of Leadership
A. Home churches: Acts 12:12
B. Trained associates: Acts 13:1-3
C. Spiritual gifts: Romans 12:4, 5; Ephesians 4:11-13

V. Key qualities desired in pastoral leaders

A. Enthusiasm and energy

${ }^{1}$ Robert E. Coleman, The Master Plan of Evangelism (Grand Rapids, MI: Fleming H. Revell, 1994), 27-116. 
B. Testimony of a personal relationship with God

C. Dedication

D. Spirit-filled

E. Willingness to designate time apart with God

Discussion

Closing remarks and prayer 
APPENDIX C

SEMINAR ON THE ROLE OF THE PASTOR

IN EQUIPPING THE LAITY 


\section{APPENDIX C}

\section{SEMINAR ON THE ROLE OF THE PASTOR IN EQUIPPING THE LAITY}

PARTICIPANTS: Administrators, pastors, and interns of WJC.

TIME: Sundays, 9:30 a.m. - 3:00 p.m.

LESSON OBJECTIVE: The purpose of this seminar is to identify the role of the pastor in equipping the laity.

\section{SAMPLE MODULE:}

Opening: Season of prayer

Presentation:

I. Old Testament model of equipping
A. Implementing advice: kings consulted the prophets
B. Decentralizing authority: the Israelites were divided into camps with leaders
C. Delegating responsibility: assignments according to gifts in building and rebuilding
D. Training successive leadership, legacy: Moses and Joshua, Elijah and Elisha

II. New Testament model of equipping
A. Jesus invested time with a few: Disciples
B. Seventy sent out two-by-two: Jesus sent out more than the twelve disciples
C. Community under Peter: church organization, a priesthood of believers
D. Mentoring: Paul and Barnabas, Paul and Timothy

III. Ellen White's views on equipping the laity
A. Small groups: Evangelism, p. 115
B. Educating rather than sermonizing: 7T, pp. 20,21
C. Pastoral mentoring

T. Early Adventism

A. Pastors facilitated small group ministries led by laity 
B. Pastors were church planters working with local members

C. Pastors were mission-minded and inspired members to support laity-led projects

D. Itinerant ministry resulted in lay leadership in the absence of the pastor

Discussion: The discussion topic centers on the results of equipping the laity.

1. How does equipping enhance the relationship between the pastors and members?

2. What are the ways in which equipping increases lay involvement in church activities?

3. How does equipping help members to identify their spiritual gifts?

4. How does equipping help pastors to assume the role of facilitator in training the laity?

5. What are the ways in which equipping reduces stress to the pastor and his family?

6. How does equipping promote a caring relationship among the members?

Closing remarks and prayer 
APPENDIX D

SEMINAR ON DEVELOPING A MODEL

TO EQUIP THE LAITY 
SEMINAR D

\section{SEMINAR ON DEVELOPING A MODEL TO EQUIP THE LAITY}

PARTICIPANTS: Administrators, pastors, and interns of WJC

TIME: Sundays, 9:30 a.m. - 3:00 p.m.

LESSON OBJECTIVE: Evaluate the data from the surveys regarding the areas of equipping the laity for ministry and develop a model for equipping the laity.

\section{SAMPLE MODULE:}

Opening: Season of prayer

Presentation:

I. Current practice of pastors in equipping the laity in the WJC.

II. Needs expressed by the pastors

III. Needs expressed by the members
A. How to conduct a Bible study
B. How to lead others
C. How to prepare sermons
D. How to organize small group ministries
C. Visitation
E. Understanding of spiritual disciplines
F. Exposure to Ellen White's writings
E. Discipling fellow members

IV. Suggested sequence for training lay leaders to equip members
A. Inform and solicit the support of the conference
B. Inform the church of your plans
C. Present the plan to the Board
D. Meet with elders/leaders/Church officers
E. Organize small groups in areas of training 
F. Group members select leader and assistant of each group

G. Meet with small group leaders and discuss plans with them

H. Plan a series of seminars with the leaders

1. Self-leadership

2. Leadership

3. Roles of the pastor, the leaders, the members

4. Small group training
a. Bible study
b. Preaching
c. Facilitating small groups
d. Fasting, prayer, meditation, and other spiritual disciplines
e. Giving the ministry away; training for successive leadership

Discussion: Pastors will be organized into small groups, each group will discuss two of the topics below, after which one person will report on behalf of the group.

1. What is a small group?

2. What are some keys to a successful small group?

3. What are the types of small groups?

4. What are the conditions that build a small group?

5. How important is the leader in a small group?

6. What are the qualifications of the leader of a small group?

7. What are the leadership styles?

8. How important is the leadership meeting in a small group?

Closing remarks and Prayer

Discussion

Closing remarks and prayer 
APPENDIX E

PASTORAL SURVEY 


\section{Andrews University Theological Seminary \\ Survey: Equipping the Laity for Ministry \\ West Jamaica Conference of Seventh-day Adventists}

Dear Pastor,

You have accepted the challenge of being one of the leaders in God's work.

Therefore, your prayerful and thoughtful response to the following questionnaire can make a difference in your ministry and the life of your church.

The Conference President, Pastor Basil Reid, has given permission for the pastors in the West Jamaica Conference to participate in this study. Your participation is voluntary. You may discontinue your participation in this study at any time without any penalty or prejudice. There is no compensation in return for your participation.

Please do not include your name. By completing this questionnaire, you are giving permission for the information to be included in a study to develop strategies for equipping the laity for ministry.

Thank you for your participation, Pastor Eldon Walker

The survey is divided into four sections. Please follow the instructions at the beginning of each section and complete all questions.

Section I: Profile

Instructions: Choose the one response that best applies to you and mark it by writing an $\mathrm{X}$ in the space provided.

1. Highest education level attained:

high school college

MA MDiv doctorate

2. Years in the ministry:

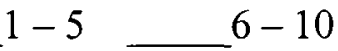

$11-20$

$21-30$

31 or more

3. Average time in personal prayer each day: 15 minutes 30 minutes 60 minutes 90 minutes or more

4. Average time in personal Bible study each day: less than an hour one hour two hours three hours or more

5. Time spent preparing each sermon: less than an hour one hour two hours three hours or more 
6. Indicate the number of sources used in preparing a sermon: one three - four five - seven nine or more

7. Time spent in family worship each day: 5-10 minutes _ $11-20$ minutes _ $21-30$ minutes $\_31$ minutes or more

8. Time spent in leisure activities each week: less than an hour one hour two hours three hours or more

Section II: Leadership

Instructions: Indicate the extent to which you agree with each of the following statements, using the following scale. Circle the number that corresponds with your assessment.

1-strongly disagree 2-disagree 3-neutral 4-agree 5-strongly agree

9. The role of the pastor is to help members identify their gifts.

10. The most effective method of evangelism occurs when members use their gifts.

11. The members usually depend on the pastor for making decisions.

$\begin{array}{lllll}1 & 2 & 3 & 4 & 5\end{array}$

12. The pastor needs to be approachable at all times.

$\begin{array}{lllll}1 & 2 & 3 & 4 & 5\end{array}$

13. The pastor must be a part of each of the activities of the church.

14. It is usually better for the pastors to do the work of the church.

$\begin{array}{lllll}1 & 2 & 3 & 4 & 5\end{array}$

15. The members accept the leadership of the pastor because of the title or position of authority.

16. Due to the responsibilities of the pastor, tardiness is understood.

17. The pastor's involvement in all of the activities of the church shows the members that he is supportive.

18. The members need to make appointments if they wish to talk with the pastor.

19. After consulting with the members, the pastor should still make the final decisions.

20. The number of baptisms reflects the effectiveness of the pastor. 
21. Members who criticize the pastor should be avoided.

22. The pastor needs to protect the traditions of the church

23. If a few members of the church want to change the traditions, the pastor should be receptive to the suggestions.

24. The pastor should resist change. $\begin{array}{lllll}1 & 2 & 3 & 4 & 5\end{array}$

$\begin{array}{lllll}1 & 2 & 3 & 4 & 5\end{array}$

$\begin{array}{lllll}1 & 2 & 3 & 4 & 5\end{array}$

$\begin{array}{lllll}1 & 2 & 3 & 4 & 5\end{array}$

\section{Section III: Conference}

Instructions: Each item below describes a level of satisfaction about your experiences in the ministry for the past three years. On the right, tell us how satisfied you are with the aspect of your ministry and the process of equipping the members for ministry. Use the scale of $1-5$ with 1 indicating that you are very dissatisfied and 5 that you are very satisfied. Circle the number that most closely corresponds with your satisfaction.

1-strongly disagree 2-disagree 3-neutral 4-agree 5-strongly agree

25. The conference sets the number of baptisms as the top priority.

$\begin{array}{lllll}1 & 2 & 3 & 4 & 5\end{array}$

26. The conference sponsors training programs for pastors.

$\begin{array}{lllll}1 & 2 & 3 & 4 & 5\end{array}$

27. The conference encourages pastors to train new members for ministry.

$\begin{array}{lllll}1 & 2 & 3 & 4 & 5\end{array}$

28. The conference encourages a holistic program for evangelism.

$\begin{array}{lllll}1 & 2 & 3 & 4 & 5\end{array}$

29. The conference makes an evangelism budget available to pastors.

$\begin{array}{lllll}1 & 2 & 3 & 4 & 5\end{array}$

30. The conference goals for baptism are established by the local church. $\begin{array}{lllll}1 & 2 & 3 & 4 & 5\end{array}$

31. The conference vision for evangelism is known by the pastors

$\begin{array}{lllll}1 & 2 & 3 & 4 & 5\end{array}$

32. The conference has a plan for nurturing new members.

$\begin{array}{lllll}1 & 2 & 3 & 4 & 5\end{array}$

33. The conference administrators are available if you need to consult with them or make an appointment.

$\begin{array}{lllll}1 & 2 & 3 & 4 & 5\end{array}$

34. The conference policies support the pastor's role as a facilitator for change in the local church.

$\begin{array}{lllll}1 & 2 & 3 & 4 & 5\end{array}$

35. The conference policies allow for a variety of approaches to involving the laity in ministry. 
Section IV: Ministry

Instructions: Each item below describes a level of satisfaction for the past three years: or asks for information regarding your ministry.

36. To what extent are you satisfied with the way members are being equipped for ministry: very dissatisfied $1 \begin{array}{lllllll}1 & 2 & 3 & 4 & 5 & \text { very satisfied }\end{array}$

37. To what extent are you satisfied with the way members are involved in making home visits: very dissatisfied $1 \begin{array}{llllll}1 & 2 & 3 & 4 & 5 & \text { very satisfied }\end{array}$

38. To what extent are you satisfied with the way members are involved in evangelism:

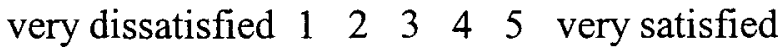

39. How satisfied are you with the level of training you received in conducting a "spiritual gift" seminar? very dissatisfied $\begin{array}{llllllll}1 & 2 & 3 & 4 & 5 & \text { very satisfied }\end{array}$

Instructions: Place an $\mathrm{X}$ in the space provided that most reflects the information.

40. Number of members you currently pastor:

200 or less _ـ $201-500 \_501-1,000 \_1001$ or more

41. Number of baptisms you have performed during the past year:

100 or less $\_101-250 \_251-500 \_501$ or more

42. Number of workshops conducted to train the laity to give Bible studies:

none one two three four five or more

43. Number of evangelistic efforts conducted by the pastor:

none one two three four five or more

44. Number of evangelistic efforts conducted by the laity:

none one two three four five or more

45. Methods of evangelism most commonly used in your churches: tent crusade church crusade home Bible study personal

46. Approximately how many members do you visit each week:

$$
1-3
$$$$
4-6
$$

$7-9$ $10-12$ 13 or more 
47. Number of organized small groups that visit the communities each week:

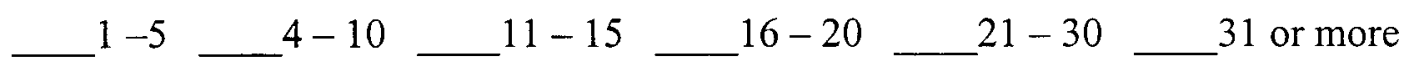

48. Number of persons baptized from these small groups during the past year:

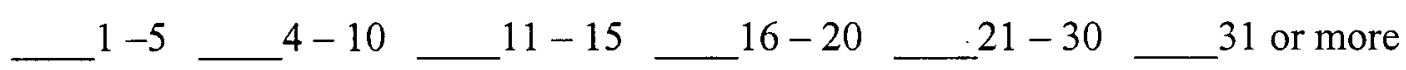

48. Indicate the number of spiritual gift seminars conducted in your churches during the past year:

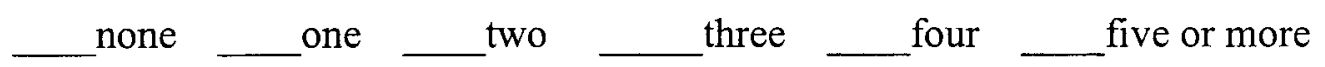

49. Indicate the number of seminars conducted during the past year to train elders in the art of preaching:

_none _one _ _ two _three f__ four __ five or more

Section V: Priorities

List strategies or methods you feel are essential for equipping the laity for ministry:

1.

2.

3.

4.

5. 


\section{APPENDLX F}

MEMBER SURVEY 


\section{Andrews University Theological Seminary \\ Survey: Equipping the Laity for Ministry \\ West Jamaica Conference of Seventh-day Adventists}

Dear Church Member,

You are being invited to participate in a survey. The results of this study are intended to enhance the role of the pastor and the church member as they work together to make ministry more effective.

Please do not include your name. By completing this form, you are giving permission for the results to be included in the study.

Thank you for your participation, Pastor Eldon Walker

The survey is divided into five sections. Please follow the instructions at the beginning of each section and complete all questions.

Section I: Profile

Instructions: Choose the one response that best applies to you and mark it by writing an $\mathrm{X}$ in the space provided.

1. How many years have you been a member of the Seventh-day Adventist church?
$1-5$
$6-10$
$11-20$
$21-30$
31 or more

2. Average time in personal prayer each day:

15 minutes $\_30$ minutes _ـ 60 minutes $\_90$ minutes or more

3. Average time in personal Bible study each day:

less than an hour

one hour

two hours

three hours or more

4. Time spent in family worship each day:

_ 5 - 10 minutes _ $11-20$ minutes _ $\_21-30$ minutes _ 31 minutes or more

5. How many times have you read the Bible through?

once twice three times four or more 
6. How many persons do you pray for each week?
1,2 $3-5$ $6-8$ $9-11$ 12 or more

Section II: Pastoral Leadership

Instructions: Indicate the extent to which you agree with each of the following statements, using the following scale. Circle the number that corresponds with your assessment.

$$
1 \text { - strongly disagree } \quad 2 \text { - disagree } \quad 3 \text { - neutral } 4 \text { - agree } 5 \text { - strongly agree }
$$

6. The pastor helps members identify their spiritual gifts.

$\begin{array}{lllll}1 & 2 & 3 & 4 & 5\end{array}$

8. The members usually depend on the pastor for making decisions. $\begin{array}{lllll}1 & 2 & 3 & 4\end{array}$

9. Your pastor is someone easy to talk with at any time

10. The pastor must be a part of each of the activities of the church.

11. It is usually better for the pastor to do the work of the church.

12. The members accept the leadership of the pastor because of the title or position of authority.

13. Due to the many responsibilities of a pastor, tardiness is understood. $\begin{array}{lllll}1 & 2 & 3 & 4 & 5\end{array}$

14. The pastor's involvement in all of the activities of the church shows the members that the pastor is supportive.

15. The members need to make appointments if they wish to talk with the pastor.

16. After consulting with the members, the pastor should still make the final decisions. 
Section III. Church Ministry

Instructions: Each item below describes a level of satisfaction about your experiences in the church. Use the scale of $1-5$ with 1 indicating that you are very dissatisfied and 5 that you are very satisfied. Circle the number that most closely corresponds with your satisfaction.

17. To what extent are you satisfied with the priority your church places on the baptism $\begin{array}{lllllllll}\text { of new members? } & \text { very dissatisfied } & 1 & 2 & 3 & 4 & 5 & \text { very satisfied }\end{array}$

18. To what extent are you satisfied with the way members are being equipped for ministry? $\quad$ very dissatisfied 11203045 very satisfied

19. To what extent are you satisfied with the way members are trained to make home visits? very dissatisfied $1 \begin{array}{lllllll}1 & 2 & 3 & 4 & 5 & \text { very satisfied }\end{array}$

20. To what extent are you satisfied with the way members are involved in evangelism? very dissatisfied $\begin{array}{lllllll}1 & 2 & 3 & 4 & 5 & \text { very satisfied }\end{array}$

21. To what extent are you satisfied with the nurturing members receive? very dissatisfied $1 \begin{array}{lllllll}1 & 2 & 3 & 4 & 5 & \text { very satisfied }\end{array}$

22. To what extent are you satisfied with the way the church uses your spiritual gifts? very dissatisfied $1 \begin{array}{llllll}1 & 2 & 3 & 4 & 5 & \text { very satisfied }\end{array}$

23. To what extent are you satisfied with the way members are trained to give Bible studies? very dissatisfied $1 \begin{array}{lllllll}1 & 2 & 3 & 4 & 5 & \text { very satisfied }\end{array}$

24. To what extent are you satisfied with the way members are trained to pray for others? very dissatisfied $\begin{array}{llllllll}1 & 2 & 3 & 4 & 5 & \text { very satisfied }\end{array}$

25. To what extent are you satisfied with the way members are trained to recognize

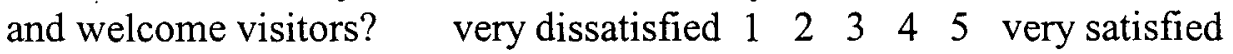

26. To what extent are you satisfied with the way members are trained to care for each other? very dissatisfied $11 \quad 2 \quad 3 \quad 4 \quad 5$ very satisfied

Section IV: Personal Ministry

Instructions: Place an $\mathrm{X}$ in the space provided that gives the best answer.

27. Number of persons you pray with each week:

$1-3 \longleftarrow 4-6 \_7$ - $9 \longleftarrow 10$ or more 
28. Number of Bible studies given each week:

none

one

two

three

four

five or more

29. Number of outreach activities you are involved in during the week:

__none __one ___ two __ three four __ five or more

30. Number of pieces of literature distributed each week:
$1-10$
$11-20$
$21-40$
$41-60$
61 or more

31. Number of evangelistic efforts conducted by your church:

none one two three four five or more

32. Number of small groups organized by your church:

none $1-3$ $4-6$ $7-9$ 10 or more

33. Are you a member of a small group for ministry in your church? no yes

34. How often does your small group meet?

not at all weekly bi-weekly monthly quarterly

34. How many persons have been baptized during the previous twelve months as a result of your small group ministry?

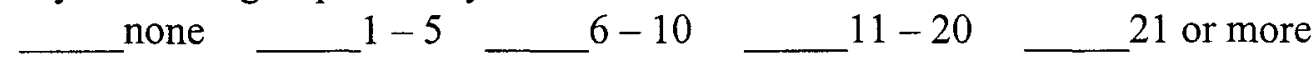

Section V: Priorities

Instructions: Give some suggestions that the pastor can use to train the members for ministry.

1

2

3

4 
APPENDIX G

LETTER 
May 14, 2002

Pastor Basil A. Reid, President

West Jamaica Conference

Post Office Box 176

Montego Bay, St. James

Jamaica, West Indies

Dear Pastor Reid:

Accept my sincere Christian greetings! I am writing my dissertation on the topic of the role of the pastor in equipping the laity for ministry in the West Jamaica Conference. As a result, I will have to develop questionnaires that will relate to the issue of the pastor equipping the laity for ministry.

Furthermore, the Office of Scholarly Research at Andrews University is requesting a letter of consent from you giving me permission to do a survey among the pastors. I am planning to be in Jamaica from May $29^{\text {th }}$ through June $5^{\text {th }}$. I would like to conduct the survey while I am in the country. It would be extremely helpful if you endorsed the project and gave your permission to distribute it to each of the pastors in the conference.

Having worked with the conference for sixteen years, I feel this study can make a real contribution to the pastoral ministry. Involving the laity helps relieve the pastor, encourages growth in the pastor's leadership skills, and facilitates the development of dynamic, vibrant, and happy church members. In order to expedite this process, kindly email your approval for the project to Michael Pearson, Associate Director for the department of Scholarly Research: mpearson@andrews.edu. My e-mail address is walkerel@andrews.edu and my telephone: 616-471-6444.

Give my regards to your family and to the entire work force. I look forward to visiting with you.

Thank you for your assistance as I begin the dissertation process.

Sincerely,

Eldon G. Walker 
APPENDIX H

SEMINAR EVALUATION 


\section{APPENDIX H}

\section{Seminar Evaluation}

Reflecting on the seminars, kindly indicate your level of agreement with the statements one through eight. On a scale of one to five, circle the number that indicates your level of agreement, left to right with one representing strong agreement and ten strong disagreement.

Strongly Disagree

Somewhat Neutral Somewh Disagree

(2)

(3)

(2)

(3)

(2)

(3)

(2)

(3)

(2)

(3)

(2)

(3)

(2)

(3)

(2)

(3)

(4)

(1)

(4)
Strongly

Agree

1. I have been blessed by the devotional exercises

2. I gained a clear understanding from the seminars

3. I am convinced of the importance of the seminars

4. I desire to apply the principles from the seminars
Don't

Know

(5)

(0)

(5)

(0)

(5)

(0)

(5)

(0)

(5)

(0)

5. The presentations were very clear

Statements regarding the seminars

(5) (0) 7. I gained personal benefits from the seminars
(0) 8. Overall, the seminars were helpful and effective
(3)

(1)

(5)

(0)

6. There was adequate time for discussion

Kindly give your suggestions about the seminars:

(5) 
BIBLIOGRAPHY 


\section{BIBLIOGRAPHY}

Anderson, Leith. Leadership That Works. Minneapolis, MN: Bethany House Publishers, 1999.

Annan, Nelson. "More People! Is Church Growth Worth It?" Elder's Digest 8, no. 2 (July-September 2002): 7.

Arn, Win. "The Friendship Factor." In The Pastor's Growth Handbook. Pasadena, CA: Church Growth Press, 1979.

Arnold, Jeffery. The Big Books on Small Groups. Downers Grove, IL: InterVarsity Press, 1992.

Baker, Delbert, ed. Make Us One: Celebrating Spiritual Unity in the Midst of Diversity. Boise, D: Pacific Press, 1995.

Banks, Robert. Paul's Idea of Community. Boston: Hendrickson Publishers, 1995.

Barna, George. The Habits of Highly Effective Churches. Ventura, CA: Regal Books, 1999.

. Leaders on Leadership: Wisdom, Advice and Encouragement. Ventura, CA: Regal Books, 1997.

. The Power of a Vision. Ventura, CA: Regal Books, 1992.

. User Friendly Churches. Ventura, CA: Regal Books, 1991.

Barker, Steve, et al. Good Things Come in Small Groups. Downers Grove, IL: InterVarsity Press, 1985.

Becker, Palmer. Called to Equip: A Training and Resource Manual for Pastors. Scottsdale, PA: Herald Press, 1993. 
Benware, Paul N., and Brian Harris. A Workbook for Discovering and Developing Leaders. Chicago, IL: Moody Press, 1991.

Black, Clinton V. The Story of Jamaica: From Prehistoric to Present. London: Collin Clear Type Press, 1965. . Jamaica Guide. London: Collins Clear Type Press, 1973.

Bosch, David J. Transforming Mission: Paradigm Shifts in Theology and Mission. Maryknoll, NY: Orbis, 1999.

Brown, Patricia. Learning to Lead from Your Spiritual Center. Nashville, TN: Abingdon Press, 1996.

Burrill, Russell C. Rediscovering an Adventist Approach to the Life and Mission of the Local Church. Fallbrook, CA: Heart Research Center, 1998.

. Revolution in the Church: Unleashing the Awesome Power of the Lay Ministry. Fallbrook, CA: Hart Research Center, 1993.

. The Revolutionized Church for the $21^{\text {St }}$ Century. Fallbrook, CA: Hart Research Center, 1997.

CIA. "Jamaica." World Factbook, 2002. http//www.odci. gov/cia /publications/ factbook/ print/jm.html (2 November 2002).

Choi, Paul Yonggi. Successful Home Cell Groups. North Brunswick, NJ: Bridge-Logos Publishers, 1999.

Clarke, Andrew. First Century Christians in a Greco-Roman World. Grand Rapids, MI: Wm. B. Eerdmans Publishing Company, 2000.

Clegg, Tom, and Warren Bird. Lost in America: How You and Your Church Impact the World Next Door. Loveland, CO: Group Publishers, 2001.

Coleman, Robert E. The Master Plan of Evangelism. Grand Rapids, MI: Fleming H. Revell, 1994.

Comisky, Joel. Reap the Harvest. Houston, TX: Touch Publications, 1999. 
Cress, James A. You Can Keep Them If You Care. Oshawa, Ontario, Canada: Maracle Press, 2000.

. "New Members and Their Extended Family." Elder's Digest 8, no. 2 (JulySeptember 2002): 6 .

Dick, Everett. Founders of the Message. Washington, DC: Review and Herald, 1938.

Dudley, Roger. Why Our Teenagers Leave the Church. Hagerstown, MD: Review and Herald, 2000.

Easum, William M. Sacred Cows Makes Gourmet Burgers. Nashville, TN: Abingdon Press, 1995.

Fernando, Henriques. Jamaica, Land of Wood and Water. New York: Maxwell Publishers, 1964.

Flynn, Bruce E. "A Survey of the Development of the Seventh-day Adventists Work in West Jamaica." A paper presented for the class CHIS570 History of the Seventhday Adventist Church, Andrews University, May 1971, 8.

Foss, Michael W. Power Surge: Six Marks of Discipleship. Minneapolis, MN: Ausburg Fortress Press, 2000.

Furgerson, Clifford Adolphus. "Origin and Growth of the Seventh-day Adventist Church in East Jamaica Conference." A paper presented for CHIS570 History of the Seventh-day Adventist Church, Andrews University, Winter 1977.

General Conference of Seventh-day Adventists. Report of the 57th General Conference Session of Seventh Adventists. 29 June-July 8, 2000.

George, Carl F. The Coming Church Revolution: Equipping Leaders for the Future. Grand Rapids, MI: Fleming H. Revell, 2000. . Preparing Your Church for the Future. Grand Rapids, MI: Fleming H. Revell, 1992.

Gladden, Ron. "Evangelism and Church Growth.” Ministry, October 1997, 7.

Gladis, George. Leading the Team-Based Church. New York: Jossey Bass, 1999. 
Grys, John, and Greg Schaller. "Growing a Healthy Church.” Ministry, March 2001, 11.

Guilianni, Rudolph W. Leadership. New York: Hyperion, 2002.

Habecker, Eugene B. Rediscovering the Soul of Leadership. Wheaton, IL: SP Publications, 1996. . Leading With a Follower's Heart. Wheaton, IL: SP Publication, 1990.

Hadidan, Allen. Discipleship: Helping Other Christians Grow. Chicago, IL: Moody Press, 1987.

Harmon, Nolan B., ed. The Interpreter's Bible. Vol. 5. Nashville, TN: Abingdon Press, 1953.

Haysmer, A. J. "West Indies." Review and Herald, December 5, 1893, 776.

. "West Indies." Review and Herald, August 10, 1895, 539.

. "West Indies." Review and Herald, September 29, 1896, 170.

Henderson, Michael D. John Wesley Class Meeting. Colorado Springs, CO: NavPress, 1995.

Hock, Dee. "The Art of Choradic Leadership." Leader to Leader, Winter 2002, 15.

Hocking, David. The Seven Laws of Christian Leadership. Ventura, CA: Regal Books, 1991.

Hornsby, Bill. The Cell Driven Church. Mansfield, PA: Kingdom Publishing, 2000.

Hull, Bill. Jesus Christ, Disciple Maker. Old Tappan, NJ: Fleming H. Revell, 1990.

Humphrey, J. H. "Jamaica." Review and Herald, 12 October 1897, 650.

Hurwitz, Samuel J., and Edith F. Hurwitz. Jamaica: A Historical Portrait. NewYork: Praegers Publishers, 1971.

Hybels, Bill. Too Busy to Pray: Slowing Down to Be With God. Downers Grove, IL: InterVarsity Press, 1998. 
Kenaope, Kenaope. "The Factors That Influenced Church Growth in Botswana." D.Min. dissertation, Andrews University, 2003.

Johnson, Kurt W. Small Groups for the End-time. Hagerstown, MD: Review and Herald, 1997.

Johnson, Douglas W. Don't Know Much About Being a Leader in My Church. Nashville, TN: Abingdon Press, 1996.

Johnstone, Patrick, Jason Mandryk, and Robyn Johnstone. Operation World: $21^{S T}$ Century Edition. Waynesboro, GA: Paternoster Publishing, 2001.

Jones, Laurie Beth. Jesus CEO: Using Ancient Wisdom for Visionary Leadership. New York: Laurie Beth Jones, 1995.

Lawes, Princess. "Welcome to North Jamaica Mission." Visitor, Third Quarter 2002, 11.

Lawson, Gregory. "The Utilization of Home Cell Groups in Leadership Development and Local Church Ministry." Christian Educational Journal 8 (Spring 1993): 67.

Lewis, Larry B. Organize to Evangelize: A Manual for Church Growth. Nashville, TN: Broadman, 1988.

Loughborough, J. N. The Church: Its Organization Order and Discipline. Washington, DC: Review and Herald. 1907.

Mack, Michael. The Strategy Church. Grand Rapids, MI: Baker Books, 1996.

Malphurs, Aubrey. Value-Driven Leadership. Grand Rapids, MI: Baker Books, 1996. - Strategy 2000: Churches Making Disciples for the Next Millennium. Grand Rapids, MI: Kregel Publications, 2000.

Maxwell, John C. Developing the Leader Within You. Nashville, TN: Thomas Nelson Publishers, 1992.

McBride, Neal F. How to Lead a Small Group. Colorado Springs, CO: NavPress, 1992.

McClure, Alfred C. "Planting and Harvesting." Adventist Review, December 1996, 11. 
McGavran, Donald. Understanding Church Growth Principles. Grand Rapids, MI: Eerdmans, 1980.

McGavran, Donald, and Winfield C. Arn. Ten Steps for Church Growth. New York: Harper and Row, 1977.

McGrath, Allister E. Christian Spirituality. Malden, MA: Blackwell Publishers, 1999.

McIntosh, Gary L. One Size Doesn't Fit All. Grand Rapids, MI: Fleming H. Revell, 1999.

Milavec, Aaron. To Empower as Jesus Did: Acquiring Spiritual Powers Through Apprenticeship. New York: Edwin Press, 1982.

Mitchell, Linette. The Light Is Come: A Short Story of the Seventh-day Adventist Church in Jamaica. Kingston, Jamaica: Linette Mitchell, 1990.

Morris, Margaret. Tour Jamaica. Jamaica, Kingston: The Gleaner Company,1985.

Nichol, Francis D., ed. The Seventh-day Adventist Bible Commentary, vol. 2. Washington, DC: Review and Herald Publishing Association, 1976.

Norton, Ricardo. Class notes for Equipping the Lay Leaders for Church Growth. Andrews University, Berrien Springs, Michigan, April 2000.

Perry, Olson. "Festival of the Laity." Lake Union Herald, June 2002, 6-11.

Perez, Eric C. "Pastoral Models." Essay Classification, 24 September 2002 1-2.

Pointer, Roy. How Do Churches Grow: A Guide to the Growth of Your Church. London: MARC Europe, 1984.

"Poverty on the Rise." The Jamaica Gleaner, October 19, 2001, 12.

Purves, Andrew, and Charles Partee. Encountering God: Christian Faith in Turbulent Times. Louisville, KY: Abingdon Press, 2000.

Rhone, Denton. Churching the Rich. Mandeville, Jamaica: Dikah Publishers, 2001.

Rima, Samuel D. Rethinking the Successful Church: Finding Serenity in God's Sovereignity. Grand Rapids, MI: Baker Books, 2002. 
Rush, Myron. The New Leader: A Revolutionary Approach to Leadership. Colorado Springs, CO: Victor Books, 1989.

Sahlin, Monte. Sharing Our Faith. Hagerstown, MD: Review and Herald. 1989.

Samaan, Phillip G. Christ's Way to Spiritual Growth. Hagerstown, MD: Review and Herald, 1995.

Schwarz, Christian A. Natural Church Development. Emmelsbull, Germany: C\&P Publishing, 1998.

Seventh-day Adventist Encyclopedia. 2 vols. Washington, DC: Review and Herald Publishing Association, 1966.

Seventh-day Adventists Believe ... A Biblical Exposition of 27 Fundamental Doctrines. Hagerstown, MD: Review and Herald Publishing Association, 1988.

Seventh-day Adventist Church Manual. Rev. ed. Hagerstown, MD: Review and Herald Publishing Association, 2000.

Seventh-day Adventist Yearbook. Hagerstown, MD: Review and Herald Publishing Association, 1995-2002.

The Seventh-day Adventist Minister's Handbook. Silver Spring, MD: The Ministerial Association, General Conference of Seventh-day Adventists, 1997.

Shaw, Whitford A. "History of the Seventh-day Adventist Work in Jamaica Between 1893-1903." A Paper Presented for CHIS570 History of Seventh-day Adventist Church, Andrews University, Spring 1978.

Sider, Ronald. Genuine Christianity. Grand Rapids, MI: Zondervan Publishing House, 1996.

Steinbron, Melvin J. Can the Pastor Do It Alone? A Model for Preparing Lay People for Lay Pastoring. Ventura, CA: Regal Books, 1987.

Strickland, J. A. "The Fieldwork: Northern Jamaica." Review and Herald, 12 September 1904, 17.

Sweeting, George. How to Begin the Christian Life. Chicago, IL: Moody Press, 1993. 
Swindoll, Charles R. Start Where You Are. Nashville, TN: Word Publishing, 1999.

Thompson, Oscar W., Jr. Concentric Circle of Concern. Nashville, TN: Broadman, 1981.

Timm, Alberto R. "Reviving Inactive Churches.” Ministry, February 1992, 13-15.

Wagner, C. Peter. Your Spiritual Gifts: How to Find Your Gifts and Use Them to Bless Others. Ventura, CA: Regal Books, 1994.

. Strategies for Church Growth: Tools for Effective Mission and Evangelism. Ventura, CA: Regal Books, 1987.

Warren, Rick. The Purpose Driven Church. Grand Rapids, MI: Zondervan Publishing House, 1995.

Watson, Paul E. "Equipping Church Members in Community: A Follow-up Strategy for Spiritual Body-Building Groups in the Brandon Seventh-day Adventist Church." D.Min. dissertation, Andrews University, 2001.

West Jamaica Conference of Seventh-day Adventists. Report of Meetings of the First Quadrennial Session, 3-7 July 2002.

White, Ellen G. Christian Service. Washington, DC: Review and Herald, 1947.

. "Christian Work." Review and Herald, 10 October 1882, 625.

. Desire of Ages. Mountain View, CA: Pacific Press, 1940.

. Education. Mountain View, CA: Pacific Press, 1902.

. Evangelism. Washington, DC: Review and Herald, 1948.

. Gospel Workers. Washington, DC: Review and Herald, 1948.

. The Great Controversy. Mountain View, CA: Pacific Press, 1950.

. "Labor at Camp Meeting." Signs of the Times, 17 May 1883, 348.

. Life Sketches. Mountain View, CA: Pacific Press, 1915. 
. Ministry of Healing. Mountain View, CA: Pacific Press, 1942.

. Pastoral Ministry. Washington, DC: Review and Herald, 1948.

. Review and Herald, July 1889.

. "Seek First the Kingdom of God." Review and Herald, January 1893, 65.

. Testimonies for the Church. 9 vols. Mountain View, CA: Pacific Press, 1948.

. This Day With God. Washington, DC: Review and Herald, 1979.

White, James. Life's Sketches. Vol. 1. Battle Creek, MI: Steam Press, 1868.

. "Report of Conference Address." Review and Herald, June 9, 1859, 21.

. "Report of Conference Address." Review and Herald, April 15, 1862, 156.

Youngblood, Ronald F., ed. Nelson New Bible Dictionary. Nashville, TN: Thomas Nelson Publishers, 1986.

Zvandasara, Nkosiyabo. "Strategic Church Planning in the Central Zimbabwe Conference." D.Min. dissertation, Andrews University, 1998. 
VITA 
VITA

Name: Eldon Gosnel Walker

Date and Place of Birth: June 22, 1955, Delveland/Westmoreland, Jamaica

Marital Status: Married on August 29, 1987 to Pauline with two beautiful children Donnel and Donnene

\section{Education:}

1976 - Savanna-La-Mar High School, Westmoreland, Jamaica

1979 - Bachelor of Theology, Northern Caribbean University, Mandeville, Jamaica

1983 - Masters of Arts, Andrews University, Seventh-day Adventist Theological Seminary, Berrien Springs, Michigan

1999 - 2000 M. Div. equivalency

2001 - 2003 Doctor of Ministry, Andrews University, Seventh-day Adventist Theological Seminary, Berrien Springs, Michigan

\section{Professional Experience:}

1983-86 - Teacher, Savanna-La-Mar High School

1986-88 - Pastoral Internship, West Jamaica Conference of SDA, Montego Bay, Jamaica

1988-91 - Pastor, Chambers Pen Circuit of Churches (9 churches), West Jamaica Conference of SDA

1991-94 - Pastor Jointwood Circuit of Churches (9 churches), West Jamaica Conference of SDA Jamaica (Centurion) 
1994-98 - Pastor, Southfield Circuit of Churches (8 churches), West Jamaica Conference of SDA, Jamaica (Centurion)

1998-99 - Pastor, Hopewell Circuit of Churches (9 churches), West Jamaica Conference of SDA, Jamaica

2001-02 - Elder and Personal Ministries Director, Lake Region Conference of SDA Berrien Springs, Michigan

2003 - Pastor, Margate SDA Mission, 6060 SW $7^{\text {th }}$ Street, Margate, FL 33063

\section{Ordination :}

December 7, 1991, West Jamaica Conference of Seventh-day Adventists, Post Office Box 176, Catherine Hall, Montego Bay, St. James. Jamaica

\section{Highlights:}

2001 - Award: Dehaan Work Excellence Scholarship, Andrews University

1999 - Highest Baptismal Record in West Jamaica Conference - 354 precious souls 